\title{
STUDIES ON INFLUENZA IN THE PANDEMIC OF 1957-1958. II. PULMONARY COMPLICATIONS OF INFLUENZA * $\dagger$
}

\author{
By DONALD B. LOURIA, $\ddagger$ HERBERT L. BLUMENFELD, JOHN T. ELLIS, \\ EDWIN D. KILBOURNE, AND DAVID E. ROGERS
}

\begin{abstract}
(From the Departments of Medicine, Pathology, and Public Health and Preventive Medicine, The New York Hospital-Cornell Medical Center, New York, N. Y.)
\end{abstract}

(Submitted for publication July 10, 1958; accepted August 7, 1958)

Influenza presents a paradox. To the clinician practicing medicine in 1918, influenza was a fearsome disease attended by frequent and often fatal pulmonary complications. To the student of interpandemic influenza in the last quarter century, the disease is an acute, temporarily incapacitating infection of the upper respiratory tract which is benign except on the rare occasion when bacterial pneumonia supervenes. This contrast in the manifestations of influenza has led to speculation that the disease of 1918 was either a different disease entity or caused by an agent of greater virulence than influenza viruses now encountered.

The microbiologic and pathologic evidence accumulated during the 1918-19 pandemic established the probable bacterial etiology of most influenza fatalities. There were, however, many clinicians who insisted that certain patients died of fulminating illness unassociated with known bacterial pathogens. This impression received support in the studies of Goodpasture who presented pathologic evidence of a diffuse hemorrhagic pneumonia in two patients which was unassociated with the demonstrable presence of bacteria (2).

The pandemic of 1918-19 antedated the first recognition of the influenza A virus (Smith, Andrewes and Laidlaw, 1933 [3]). Thus, knowl-

* This work was supported in part by Traineeship Grant E-6 and Research Grants E-2162 and E-1078 from the National Institute of Allergy and Infectious Diseases, Public Health Service; The Research and Development Division, Office of the Surgeon General, Department of the Army under contract number DA-49-007-MD-703; and by grants from Chas. Pfizer \& Co., Brooklyn, N. Y.; The Upjohn Co., Kalamazoo, Mich.; and Wyeth Laboratories, Philadelphia, $\mathrm{Pa}$.

+ A preliminary report of a part of this investigation has been presented before the Association of American Physicians and has been published in the Transactions of that society (1).

$\ddagger$ Research Fellows in Medicine. edge of influenza derived from modern virologic studies of the epidemic (interpandemic) disease must be applied with caution to the 1918-19 pandemic. In the new pandemic in 1957, certain old questions remained unanswered:

1. What is the etiologic agent of pandemic influenza?

2. Is the pandemic disease more severe than the interpandemic form or only more widespread?

3. Is bacterial pneumonia the major cause of fatalities in pandemic influenza; if so, may fatalities be prevented by modern antimicrobials?

4. May influenza virus induce fatal disease in the absence of bacterial pathogens?

The first question has been unequivocally answered. A virus biologically indistinguishable from viruses previously isolated from cases of epidemic influenza may cause pandemic disease. The etiological agent of the 1957-58 pandemic, the socalled Asian strain of influenza virus, differs antigenically from previously isolated viruses, but is nonetheless a strain of influenza A virus. Furthermore, recent serologic studies suggest antigenic similarity of the virus of the 1957 pandemic to the agent of the pandemic of 1889 (4).

The definitive answer to the second question must await analysis of data from the present pandemic, but preliminary evidence suggests that pandemic influenza does not differ clinically from the epidemic disease $(5,6)$.

Partial answers to the final questions are subjects of the present paper. This investigation of patients with pulmonary complications of influenza was organized in the fall of 1957 as a prospective study of disease in the new pandemic. The results represent a collaborative integration of laboratory and bedside investigations.

During the 1957-58 influenza pandemic more than 50 patients with influenza and evidence of lower respiratory tract involvement were admitted 
to The New York Hospital. Extensive clinical and laboratory observations were made on 33 individuals in this group in whom influenza virus infection could be clearly documented. As these studies progressed it became apparent that four pulmonary syndromes could be differentiated on the basis of history, physical examination, the appearance of chest $\mathrm{X}$-rays, bacteriologic and virologic studies and the subsequent course of the illness. These syndromes have been categorized as follows :

1. Influenza virus infection with physical signs of lower respiratory tract involvement without infiltrates detectable by roentgenography.

2. Influenza virus infection followed by secondary bacterial pneumonia.

3. An acute, rapidly progressive pneumonia apparently produced by influenza virus infection alone.

4. Concomitant viral and bacterial pneumonia.

The present paper describes and defines these clinical entities. Included in this report are the results of laboratory and physiologic studies, the course of illness, the therapy employed and the microbiologic and histologic studies of tissues obtained post mortem.

\section{MATERIALS AND METHODS}

All 33 patients were hospitalized at The New York Hospital. Thirty patients were studied on the medical wards. Three pregnant women were studied on the obstetrical service.

1. Clinical studies. Each patient was initially examined by the house staff. When the clinical history was compatible with influenza, the patient was re-examined and evaluated by a member of the influenza study group. During the acute phase of illness, each patient was examined at least once daily by members of the study group who kept detailed records on symptoms, physical findings and the course of the illness.

2. Routine laboratory studies. Certain routine studies were performed serially on all patients. These included hematocrit determinations, total and differential leukocyte counts, erythrocyte sedimentation rates, urinalyses, chest roentgenograms, blood urea nitrogen, venous carbon dioxide combining power and serum sodium, serum potassium and serum chloride determination.

3. Virologic studies. The procedures used for the isolation of influenza virus are presented in detail in the succeeding paper (7). Throat washings were obtained for influenza virus isolation on the majority of patients. Attempts were also made to recover influenza virus from specimens of peripheral blood, urine and spinal fluid in selected cases. In patients dying during the course of their disease, specimens of lung tissue removed at autopsy were frozen and stored at $-68^{\circ} \mathrm{C}$. until virus studies could be performed.

Acute serum specimens were drawn at the time of admission on all patients. Subsequent convalescent sera were obtained on one or more occasions 7 to 35 days later on patients who survived their illness. Sera were tested for the presence of hemagglutination-inhibiting and/or complement fixing antibody to the Asian strain of influenza $A$ virus by techniques detailed in the preceding paper (5).

The following criteria were arbitrarily established as definitive evidence of recent infection with the Asian strain of influenza A virus:

1. A fourfold or greater rise in complement fixing antibody between acute and convalescent sera using the Japan 305 strain of influenza A virus as the test (viral) antigen.

2. An initial complement fixing antibody titer of $1: 128$ or greater against the Japan 305 strain in patients seen on or after the seventh day of influenza symptoms. These titers were felt to represent clear evidence of influenza infection after study of a series of 55 normal individuals revealed none with baseline serum titers of complement fixing antibody above $1: 64$.

4. Bacteriologic studies. Specimens of sputum, blood, and swabs from the nasopharynx and throat were cultured from all patients. In many instances, duplicate cultures were performed within the diagnostic bacteriology laboratory of The New York Hospital and the laboratories of the Division of Infectious Disease.

Sputum specimens were plated on blood and chocolate agar plates and inoculated into liver dextrose and thioglycollate broth. Particular attention was directed to isolation of coagulase positive staphylococci, pneumococci, Hemophilus influenzae and beta hemolytic streptococci. Microorganisms were identified by appropriate subculture, biochemical reactions, staining characteristics and serologic studies.

In many instances, $1 \mathrm{ml}$. of emulsified sputum was also inoculated intraperitoneally into white mice. When animals died, the peritoneal cavity was washed with $1 \mathrm{ml}$. of sterile saline and the peritoneal exudate examined by Gram stain and inoculated upon blood agar plates and into appropriate liquid media. Animals which survived sputum inoculation were killed several days later and the peritoneal washings subjected to the same procedures.

In fatal illnesses, postmortem cultures of lung and heart's blood were obtained from all but one patient. Specimens of lung tissue were plated directly on blood agar plates and inoculated into beef heart infusion broth, liver dextrose broth, and beef heart infusion broth containing five per cent defibrinated rabbits' blood. Specimens of lung from five patients were ground under sterile conditions, and quantitative pour plates were made to ascertain the concentrations of bacteria per milliliter of lung tissue.

All staphylococcal isolates were studied for pigment 
production, hemolysis, mannitol fermentation and coagulase production. The majority of strains were subjected to bacteriophage typing using the technique of Blair and Carr (8).

Antibiotic sensitivity studies were carried out on all strains of staphylococci. Initial tests were performed utilizing the surface disc method. The discs used contained $10 \mu \mathrm{g}$. of tetracycline, chloramphenicol, streptomycin and erythromycin, 1.5 units of penicillin, and $5 \mu \mathrm{g}$. of novobiocin. In addition, standard serial tube dilution sensitivity studies were carried out on the majority of staphylococcal isolates. Beef heart infusion broth containing five per cent defibrinated rabbit blood was used as the medium. One-half $\mathrm{ml}$. of a $10^{-4}$ dilution of an 18 hour broth culture was used as the inoculum.

5. Cardiopulmonary and renal studies. Standard 12 lead electrocardiograms were obtained on 29 patients and were obtained serially on all patients who were seriously ill. Venous pressure determinations were made on or shortly following admission in 23 patients and were studied serially in patients with symptoms or signs suggestive of congestive heart failure.

Arterial blood gas studies were made in eight patients by Dr. Daniel Lukas and his associates. Blood obtained from the brachial artery was analyzed for oxyhemoglobin saturation, oxygen binding capacity, and carbon dioxide content by the method of Van Slyke and Neill (9). Arterial $\mathrm{pH}$ was performed on the same specimens using a Cambridge research model $\mathrm{pH}$ meter. Serum carbon dioxide content was calculated from the nomogram of Van Slyke and Sendroy (10). Partial pressures of arterial carbon dioxide and serum bicarbonate were calculated from the Henderson-Hasselbalch equation using a solubility coefficient of 0.0301 .

Blood plasma volumes were determined on four patients at the height of their pulmonary disease process by

TABLE I

Normal laboratory values (The New York Hospital)

\begin{tabular}{|c|c|}
\hline Determination & Normal value \\
\hline $\begin{array}{l}\text { Blood urea nitrogen } \\
\text { Serum carbon dioxide combining } \\
\text { power } \\
\text { Serum sodium } \\
\text { Serum potassium } \\
\text { Serum chloride } \\
\text { Serum glutamic oxaloacetic } \\
\quad \text { transaminase }\end{array}$ & $\begin{array}{l}\text { 8-15 mg. \% } \\
\text { 22-27 mM/L. } \\
132-143 \mathrm{mEq} . / \mathrm{L} . \\
3.5-5.3 \mathrm{mEq} / \mathrm{L} . \\
\text { 97-106 mEq./L. } \\
\text { 0-35 units/ml./min. }\end{array}$ \\
\hline $\begin{array}{l}\text { Arterial blood } \mathrm{pH} \\
\text { Arterial oxyhemoglobin } \\
\text { saturation } \\
\text { Arterial carbon dioxide content } \\
\text { Arterial partial pressure carbon } \\
\text { dioxide } \\
\text { Arterial bicarbonate } \\
\text { Blood pyruvic acid } \\
\text { Blood ketones }\end{array}$ & $\begin{array}{l}7.40 \pm 0.02 \text { units } \\
94-98 \% \\
24-27 \mathrm{mM} / \mathrm{L} . \\
39-42 \mathrm{~mm} . \mathrm{Hg} \\
22.8-25.8 \mathrm{mEq} . / \mathrm{L} . \\
60-125 \mu \mathrm{Eq} . / \mathrm{L} . \\
10-80 \mu \mathrm{Eq} . / \mathrm{L} .\end{array}$ \\
\hline $\begin{array}{l}\text { Corrected erythrocyte sedi- } \\
\text { mentation rate (Wintrobe) }\end{array}$ & $\begin{array}{l}\text { Males, } 10 \mathrm{~mm} \text {. in } 1 \mathrm{hr} \text {. } \\
\text { Females, } 20 \mathrm{~mm} \text {. in } 1 \mathrm{hr} \text {. }\end{array}$ \\
\hline
\end{tabular}

Dr. David Thompson and his associates using the T-1824 dye method of Chinard (11). T-1824 disappearance curves were also performed on two of these individuals. The dye disappearance curves obtained were compared to the values recorded in normal subjects by Noble and Gregerson (12). Phenolsulfonphthalein excretion and urea and inulin clearances were performed on selected patients.

6. Miscellaneous laboratory studies. Additional studies were performed on certain patients because of questions which arose during the course of this study.

1. Liver function tests were obtained on nine patients. These included determinations of total serum protein, albumin-globulin $(\mathrm{A} / \mathrm{G})$ ratios, total and fractionated serum bilirubin, cephalin flocculation, thymol turbidity and serum alkaline phosphatase.

2. Serum glutamic oxaloacetic transaminase levels were determined in 22 patients and were followed serially when abnormal results were encountered.

3. Studies on blood clotting were performed on five patients. These included standard bleeding and clotting times, clot retraction studies, plasma prothrombin determinations, capillary fragility tests and enumeration of blood platelets.

4. Serums were studied for the presence of cold agglutinins on from one to six occasions in 21 patients. Serum heterophile antibody was determined in $10 \mathrm{pa}-$ tients during the course of their illness.

5. Three patients developed signs and symptoms suggestive of central nervous system involvement. Electroencephalographic tracings were obtained, and studies of the cerebrospinal fluid, including attempts at virus isolation, were made in two of these patients.

6. Venous blood from two patients was analyzed for ketones and pyruvic acid by the methods of Bessman (13) and Friedemann and Haugen (14).

Values for these determinations in The New York Hospital laboratories are listed in Table I.

7. Postmortem studies. Ten patients died during the course of illness. An additional patient died with an acute myocardial infarction six weeks after discharge from the hospital. Complete postmortem studies were carried out in eight patients. In two in whom a complete autopsy was not permitted, specimens of lung were obtained by needle or incision for virologic, bacteriologic and microscopic examination.

\section{RESULTS}

\section{General description of the patients studied}

Thirty-two of the 33 patients included in this study were admitted to the hospital between Sept. 29 and Nov. 11, 1957. The remaining patient was admitted during January, 1958 (Figure 1). Patients ranged in age from 13 to 75 years. Approximately two-thirds (21 patients) were under 50 years of age. Eighteen were males and 15 were 


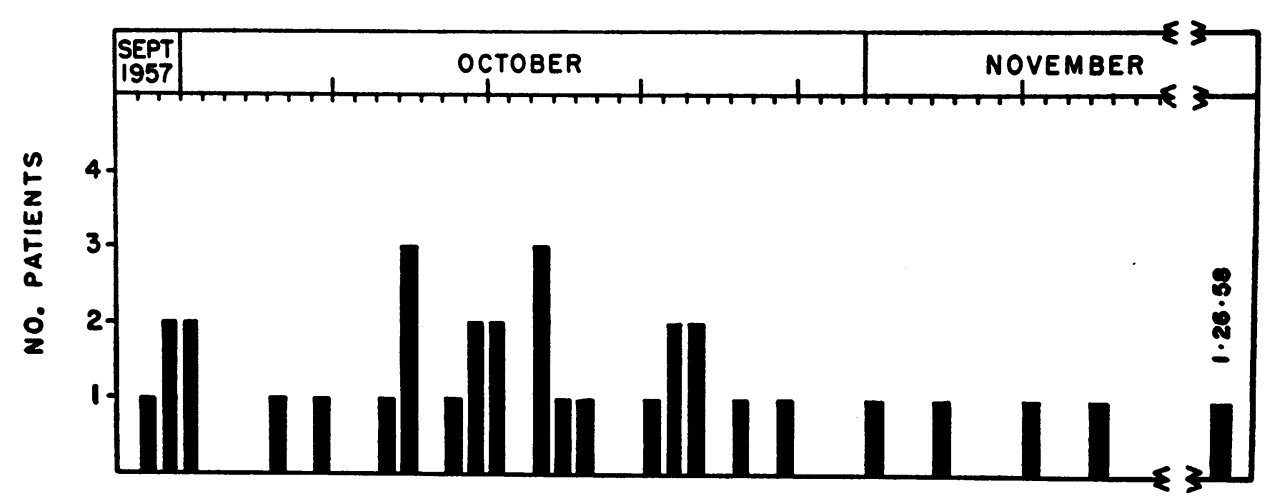

Fig. 1. Dates of Admission of Patients with Pulmonary Complications of Influenza

females. None of these patients had received influenza vaccination preceding the pandemic. Twenty-four patients had evidence of chronic disease or pregnancy antedating influenza. Symptoms suggesting the development of parenchymal lung involvement arose one to 14 days after the onset of initial influenzal symptoms.

In the following sections the four pulmonary syndromes observed are discussed separately along with the laboratory studies which aided in the characterization of each syndrome. Other laboratory studies which did not materially aid in differentiating these clinical entities are considered in the succeeding section. Subsequent sections review therapy, the course of the illnesses and studies on postmortem material. Selected case reports are included in the final section.

I. The clinical syndromes manifested by patients with influenza attended by signs of lower respiratory tract involvement

1. Influenza with physical signs of lower respiratory tract involvement without roentgenographic evidence of pneumonia

In three patients with influenza, chest findings developed which suggested parenchymal lung involvement in the absence of roentgenographic evidence of pulmonary infiltrates. All three of these individuals had evidence of underlying disease antedating the onset of influenza. Two patients had rheumatic heart disease. One patient with inactive pulmonary tuberculosis had known pulmonary hypertension as determined by previous cardiac catheterization studies.

Symptoms referable to the respiratory tract appeared within 48 hours of the onset of typical in- fluenza symptoms. All three patients exhibited high fever and marked prostration; a cough which was productive of small amounts of blood tinged sputum appeared in two. Two patients noted pleuritic chest pain. Mild dyspnea was noted by all three patients.

Physical examination of the lungs revealed unilateral or bilateral crepitant and musical inspiratory rales accompanied by diminished or harsh breath sounds. Coarse rhonchi and occasional wheezes were heard in two of the three patients. Bilateral pleural friction rubs were noted in one patient. Signs of local consolidation were absent.

Total leukocyte counts were within the normal range in two patients; moderate leukocytosis was observed in one. Erythrocyte sedimentation rates were slightly elevated. Few bacteria were seen in sputum smears, and cultures from two patients demonstrated only normal pharyngeal flora. Occasional colonies of hemolytic Staphylococcus aureus and pneumococci were grown from sputum cultures obtained from the third patient. Blood cultures were sterile.

The Asian strain of influenza A virus was isolated from the throat washing of one of the two patients from whom washings were obtained. Serologic proof of influenza virus infection was obtained in all three. Symptoms and signs persisted from three days to several weeks. In each patient a complete recovery ensued on symptomatic treatment alone.

Comment. These three patients with influenza developed signs of lower pulmonary tract disease without X-ray evidence of pneumonia. There was no convincing evidence of bacterial infection. Recovery occurred without antimicrobial therapy. 
These patients were believed to have bronchiolitis accompanying influenza. They are included to portray the full spectrum of pulmonary involvement witnessed during the epidemic, but are not considered further in the analysis of the more serious pulmonary complications of influenza.

\section{Influenza complicated by secondary bacterial pneumonia}

Fifteen patients had serologically established influenza followed by evidence of bacterial infection of the lung. These patients ranged in age from 13 to 72 years. Eight were males and seven were females.
Seven patients had evidence of pre-existing disease. Three had rheumatic heart disease with established mitral valve disease. Two patients were diabetic. One patient had bronchiectasis and pulmonary emphysema of long standing. One patient had progressive muscular dystrophy with involvement of the respiratory musculature. The remaining eight patients had no evidence of underlying disease prior to the onset of influenzal symptoms. One patient was in the third trimester of pregnancy. A summary of clinical data on these patients is recorded in Table II.

Clinical history. Ten of these 15 patients had a remarkably similar history. In each, the typical

TABLE II

Influenza complicated by bacterial pneumonia: Summary of clinical data

\begin{tabular}{|c|c|c|c|c|c|c|c|c|c|c|c|}
\hline \multirow{3}{*}{$\begin{array}{l}\text { Patient. } \\
\text { Age, } \\
\text { Sex }\end{array}$} & \multirow[b]{3}{*}{$\begin{array}{c}\text { Date of } \\
\text { admission }\end{array}$} & \multirow{3}{*}{$\begin{array}{l}\text { Under- } \\
\text { lying } \\
\text { disease* }\end{array}$} & \multirow{3}{*}{$\begin{array}{l}\text { Duration } \\
\text { of illness } \\
\text { prior to } \\
\text { pulmonary } \\
\text { symptoms }\end{array}$} & \multicolumn{8}{|c|}{ Pulmonary involvement $\ddagger$} \\
\hline & & & & \multicolumn{4}{|c|}{ Symptoms } & \multicolumn{4}{|c|}{ Signs } \\
\hline & & & & Chills & $\begin{array}{l}\text { Productive } \\
\text { cough }\end{array}$ & $\begin{array}{l}\text { Chest } \\
\text { pain }\end{array}$ & Dyspnea & $\begin{array}{c}\text { Resp./ } \\
\text { min. }\end{array}$ & $\begin{array}{c}\text { Admission } \\
\text { temp. }\end{array}$ & $\begin{array}{l}\text { Cya- } \\
\text { nosis }\end{array}$ & $\begin{array}{l}\text { Pulmonary } \\
\text { findings }\end{array}$ \\
\hline & & & days $\dagger$ & & & & & & ${ }^{\circ} \mathrm{C}$. & & \\
\hline$\underset{40}{R} . S_{F}$ & 9/29/57 & $\begin{array}{l}\text { RHD, MS, } \\
\text { MI, AF }\end{array}$ & $<1$ & $\mathbf{0}$ & 0 & 0 & ++ & 28 & 40.0 & 0 & Rales, RLL \\
\hline Ni $\stackrel{\text { Q. }}{\mathrm{M}}$ & $9 / 30 / 57$ & o & 4 & $\mathbf{0}$ & $\stackrel{+}{+}$ & ++ & + & 30 & 40.5 & $\mathbf{0}$ & Consol., RLL \\
\hline Bi. $\underset{F}{\mathrm{~N}}$ & $10 / 1 / 57$ & $\underset{\text { MII }}{\text { RHS, }}$ & $<1$ & $\mathbf{0}$ & $\stackrel{+}{+}$ & $\mathbf{0}$ & ++ & 30 & 39.8 & $\mathbf{0}$ & $\begin{array}{l}\text { Rales, harsh } \\
\text { B.S., RLL, } \\
\text { LLL }\end{array}$ \\
\hline$\underset{59}{\text { C. G. }}$ & $10 / 4 / 57$ & $\mathbf{0}$ & 3 & + & $\underset{\text { purulent }}{\stackrel{+}{+}}$ & + & 0 & 24 & 38.5 & $\mathbf{0}$ & $\begin{array}{l}\text { Consol., RLL, } \\
\text { LLL }\end{array}$ \\
\hline$\underset{13}{\mathrm{D}} \stackrel{\mathrm{P}}{\mathrm{F}}$ & $10 / 11 / 57$ & $\mathbf{0}$ & $<1$ & $\mathbf{0}$ & $\underset{\text { Purulent }}{+}$ & $\mathbf{0}$ & $\mathbf{0}$ & 26 & 39.6 & $\mathbf{0}$ & Consol., LLL \\
\hline$\underset{68}{M} \cdot \mathbf{M}$ & $10 / 14 / 57$ & $\begin{array}{c}\text { Mild } \\
\text { diabetes }\end{array}$ & 2 & $\mathbf{0}$ & $\stackrel{+}{+}$ & $\mathbf{0}$ & $\mathbf{0}$ & 22 & 38.8 & $\mathbf{0}$ & Consol., RLL \\
\hline$\underset{22}{\text { R. }} \stackrel{\text { L. }}{\text { M }}$ & $10 / 17 / 57$ & $\begin{array}{l}\text { Muscular } \\
\text { dystrophy }\end{array}$ & 4 & $\mathbf{0}$ & $\stackrel{+}{+}$ & + & ++ & 22 & 39.6 & \pm & $\begin{array}{l}\text { Consol., RUL, } \\
\text { RLL, LLL }\end{array}$ \\
\hline$\underset{45}{\mathbf{P}} \cdot \mathbf{R}$ & $10 / 17 / 57$ & $\underset{\text { MI }}{\text { RHD, }}$ & 1 & $\mathbf{0}$ & $\stackrel{+}{\text { Bloody }}$ & ++ & $\mathbf{0}$ & 28 & 38.6 & $\mathbf{0}$ & Consol., RLL \\
\hline $\begin{array}{l}\text { N. M. } \\
\mathbf{M}\end{array}$ & $10 / 22 / 57$ & $\begin{array}{l}\text { Chronic } \\
\text { pulm. dis. }\end{array}$ & 3 & + & $\underset{\text { purulent }}{\stackrel{+}{+}}$ & $\mathbf{0}$ & $\mathbf{0}$ & 20 & 40.0 & $\mathbf{0}$ & Rales, LLL \\
\hline$\underset{28}{\text { A. }} \dot{\mathrm{F}}$ & $10 / 23 / 57$ & $\mathbf{0}$ & $<1$ & + & $\underset{\text { Rusty }}{+}$ & $\mathbf{0}$ & $\mathbf{0}$ & 24 & 39.6 & $\mathbf{0}$ & Consol., RLL \\
\hline G. $\mathrm{M}$. & $10 / 24 / 57$ & $\begin{array}{l}\text { Pregnant } \\
8 \text { months }\end{array}$ & 6 & 0 & $\underset{\text { purulent }}{\stackrel{+}{+}}$ & ++ & $\mathbf{0}$ & 28 & 38.6 & $\mathbf{0}$ & $\begin{array}{l}\text { Rales, decr. } \\
\text { B.S., RLL, } \\
\text { LLL }\end{array}$ \\
\hline${ }_{72}^{\mathrm{H}} \cdot \mathrm{W}$ & $10 / 26 / 57$ & $\begin{array}{l}\text { Mild } \\
\text { diabetes }\end{array}$ & $<1$ & 0 & $\underset{\text { Mucoid }}{+}$ & ++ & o & 40 & 39.2 & + & $\begin{array}{l}\text { Rales, decr. } \\
\text { B.S., RLL, } \\
\text { LLL }\end{array}$ \\
\hline$\underset{24}{N} \underset{F}{\text { C. }}$ & $11 / 1 / 57$ & o & 14 & + & $\underset{\text { purulent }}{\stackrel{+}{+}}$ & ++ & 0 & 28 & 39.7 & 0 & Consol., LLL \\
\hline${ }_{63}^{L} F_{\dot{M}}$ & $11 / 4 / 57$ & $\mathbf{0}$ & 4 & $\mathbf{0}$ & $\stackrel{+}{+}$ & + & + & 40 & 40.4 & 0 & $\begin{array}{l}\text { Consol., RUL, } \\
\text { LLL }\end{array}$ \\
\hline$\underset{40}{\text { A. }} \stackrel{\mathrm{M}}{\mathrm{F}}$ & $11 / 11 / 57$ & 0 & 3 & 0 & $\stackrel{+}{+}$ & $\mathbf{0}$ & 0 & 24 & 37.8 & o & Consol., LLL \\
\hline
\end{tabular}

* RHD, rheumatic heart disease; MS, mitral stenosis; MI, mitral insufficiency; AF, auricular fibrillation; HCVD, hypertensive heart disease; ASCVD, arteriosclerotic heart disease; CO coronary occlusion; AS, aortic stenosis; AI, artic insufficiency.

t Where pulmonary symptoms blended with initial influenza symptoms the interval has been listed as $<1$.

Cough, chest pain, dyspnea and cyanosis are graded in severity from 0 to +++ .
RLL, right lower lung; LLL, left lower lung; RUL, right upper lung; LUL, left upper lung; B.S., breath sounds. 
influenza symptoms had been followed by a definite period of improvement. Five patients felt strong enough to return to their usual occupations. Following a period of two to 14 days (average 3.8 days), there was a sudden reappearance of symptoms which suggested the onset of pulmonary infection. A shaking chill was experienced by four patients. Eight patients developed typical pleuritic chest pain and noted a marked increase in cough which was productive of bloody or purulent sputum.

Five of the 15 patients did not have a clear cut interval between the initial influenzal illness and symptoms of pulmonary involvement. In these patients pulmonary symptoms blended with the initial illness so that it was impossible to determine the time of onset of the bacterial complication.

Physical findings. All patients in this group appeared acutely ill. As noted in Table II, admission temperatures were above $39^{\circ} \mathrm{C}$. in the majority, ranging from 38.6 to $40.5^{\circ} \mathrm{C}$. Respiratory rates were only moderately increased, ranging from 20 to 30 respirations per minute in 13 of the 15 individuals. Cyanosis was uncommon and was observed in only two patients in association with pleuritic chest pain.

Examination of the chest in each instance revealed evidence of localized disease which corresponded with the abnormalities found on roentgenographic examination. Ten patients had classic local signs of consolidation including dullness to percussion, increased fremitus, bronchial breathing, egophony and bronchophony. Five patients had localized rales, rhonchi and abnormal breath sounds without signs of classic consolidation. Single lobe involvement was observed in nine patients and bilobar disease in five. One patient had consolidation of three lobes. Signs of diffuse pulmonary involvement were not observed in these patients.

Laboratory studies. Total leukocyte counts obtained at the time of admission ranged from 3,300 to 24,600 white blood cells per cu. mm. A leukocytosis of 10,000 or more was present in 11 . Polymorphonuclear leukocytes predominated, and an increase in band forms was noted in every case. Admission white blood cell counts and the observed range of total leukocyte and absolute granulocyte counts during the acute illness are portrayed in Figure 2. Ten of the 15 patients

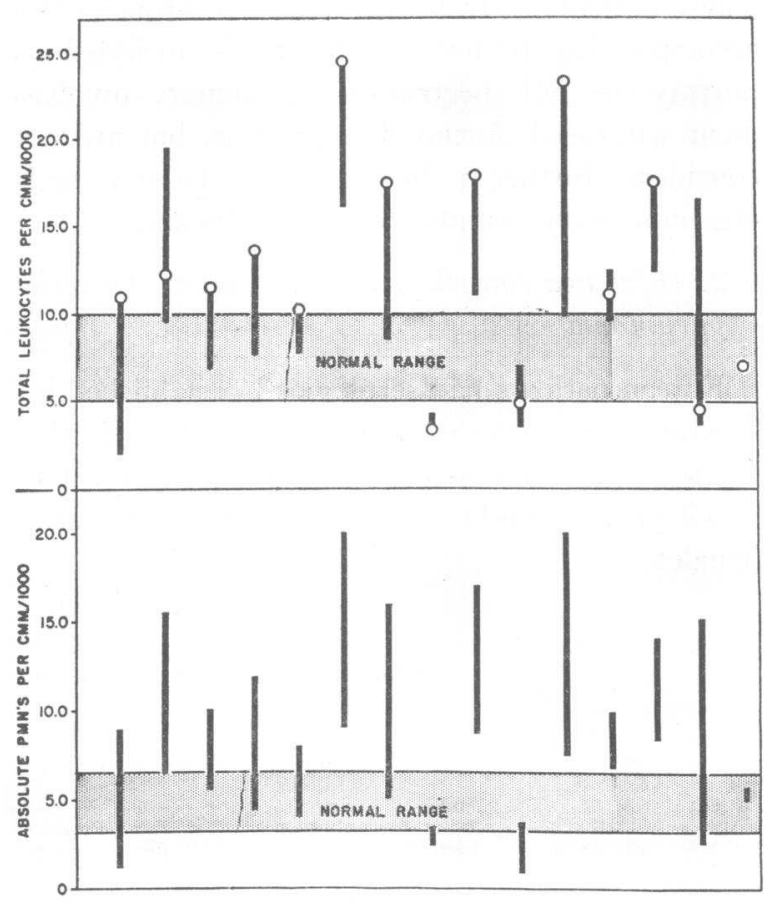

Fig. 2. Total Leukocyte and Polymorphonuclear Leukocyte Counts in Patients with Influenza Complicated by Bacterial Pneumonia

Admission white blood cell counts are indicated by the open circles; the vertical bars indicate the range in values during the acute illness.

showed elevated erythrocyte sedimentation rates at the time of their admission.

Chest roentgenograms. In all 15 patients chest roentgenograms revealed evidence of lobar or lobular involvement of the type commonly observed with bacterial pneumonia (see Figures 12, 14, and 15 accompanying the case reports). In 10, true lobar distribution of the pulmonary infiltrate was observed. Infiltrates were dense and localized and halted abruptly at fissure lines. One patient with staphylococcal pneumonia developed cavitation within the involved lobe. Empyema or the development of significant amounts of pleural fluid was not observed. In no patient in this group did X-ray films reveal extension of the process following the institution of antimicrobial therapy.

Bacteriologic findings. Sputum smears contained many polymorphonuclear leukocytes and large numbers of bacteria. A heavy growth of pneumococci was obtained in sputum and throat cultures from eight patients. Coagulase positive Staphylococcus aureus was isolated as the predomi- 
nating microorganism, or in pure culture from the sputum of three patients. Hemophilus influenzae was the only microorganism recovered from the sputum of one patient.

Sputum cultures from three patients revealed mixed bacterial growth. Both pneumococci and staphylococci were isolated in large numbers from the sputum of one patient. Coagulase positive staphylococci and Hemophilus influenzae were obtained from another, and coagulase positive staphylococci, Aerobacter aerogenes, and Candida albicans were grown from sputum cultures of one patient who acquired her disease within the hospital (Table III).

Virologic studies. Throat washings obtained from 13 patients on the third to the thirty-fifth day of illness were studied for the presence of influenza virus by methods detailed elsewhere (7). Influenza virus was not recovered from any patient in this group.

Serologic studies. Both acute sera and convalescent sera were available in eight patients. In these eight individuals, a fourfold or greater rise in complement fixing antibody titer was demon-

TABLE III

Influenza complicated by bacterial pneumonia: Summary of bacteriologic and virologic data

\begin{tabular}{|c|c|c|c|c|c|c|c|c|c|c|c|}
\hline \multirow[b]{5}{*}{ Patient } & & & \multicolumn{7}{|c|}{ Influenza virus studies } & \multirow{5}{*}{$\begin{array}{l}\text { Treat- } \\
\text { ment } \dagger\end{array}$} & \multirow{5}{*}{$\begin{array}{l}\text { Out- } \\
\text { come }\end{array}$} \\
\hline & & & & & & \multicolumn{4}{|c|}{ Complement fixation } & & \\
\hline & \multirow{2}{*}{\multicolumn{2}{|c|}{ Bacteriologic studies }} & \multicolumn{3}{|c|}{ Virus isolation } & \multirow{2}{*}{\multicolumn{2}{|c|}{$\begin{array}{c}\text { Day of illness } \\
\text { serum } \\
\text { obtained } \\
\end{array}$}} & \multirow{2}{*}{\multicolumn{2}{|c|}{$\begin{array}{l}\text { Reciprocal } \\
\text { of CF titer }\end{array}$}} & & \\
\hline & & & \multirow[b]{2}{*}{ Specimen } & \multirow{2}{*}{$\begin{array}{c}\text { Day of } \\
\text { illness } \\
\text { obtained }\end{array}$} & \multirow[b]{2}{*}{ Result } & & & & & & \\
\hline & Specimen & Cultural findings & & & & 1 & 2 & 1 & 2 & & \\
\hline R.S. & $\begin{array}{l}\text { Throat } \\
\text { blood }\end{array}$ & $\underset{0}{\text { Pneumococcus }}$ & $\mathrm{TW}^{*}$ & 3 & 0 & 6 & 19 & 16 & 4,096 & $\begin{array}{l}\mathrm{EM} \\
\mathrm{Te}\end{array}$ & Recov. \\
\hline N. Q. & $\begin{array}{l}\text { Sputum } \\
\text { blood }\end{array}$ & Hem. Staph. aureus & & & & & 22 & & 512 & $\begin{array}{l}\text { Pen } \\
\text { EM } \\
\text { SM }\end{array}$ & Recov. \\
\hline B. N. & $\begin{array}{l}\text { Sputum } \\
\text { Blood }\end{array}$ & $\begin{array}{c}\text { Few hem. Staph. aureus } \\
\text { A. acrogenes } \\
\text { Monilia } \\
0\end{array}$ & TW & 15 & $\mathbf{0}$ & 3 & 17 & 16 & 1,024 & $\begin{array}{l}\text { Pen } \\
\text { EM } \\
\text { CM } \\
\text { SM }\end{array}$ & $\begin{array}{l}\text { Expired } \\
37 \text { days }\end{array}$ \\
\hline C. G. & $\begin{array}{l}\text { Sputum } \\
\text { Blood }\end{array}$ & $\begin{array}{c}\text { Hem. Staph. aureus } \\
\text { H. influensae } \\
0\end{array}$ & TW & 12 & $\mathbf{0}$ & 14 & 24 & 512 & 1,024 & $\begin{array}{l}\text { Pen } \\
\text { EM } \\
\text { CM } \\
\text { SM }\end{array}$ & Recov. \\
\hline D. P. & $\begin{array}{l}\text { Sputum } \\
\text { Blood }\end{array}$ & $\underset{0}{\text { Pneumococcus VIII }}$ & TW & 7 & $\mathbf{0}$ & 9 & 16 & 32 & 512 & Pen & Recov. \\
\hline M. M. & $\begin{array}{l}\text { Sputum } \\
\text { Blood }\end{array}$ & $\underset{0}{\text { Pnelimococcus III }}$ & TW & 6 & 0 & 6 & 16 & 32 & 128 & Pen & Recov. \\
\hline R. L. & $\begin{array}{l}\text { Throat } \\
\text { Blood }\end{array}$ & $\underset{0}{\text { Pneumococcus III }}$ & TW & 7 & 0 & 7 & 18 & 512 & 1,024 & $\begin{array}{l}\text { Pen } \\
\text { EM } \\
\text { SM }\end{array}$ & Recov. \\
\hline P. R. & $\begin{array}{l}\text { Sputum } \\
\text { Blood }\end{array}$ & $\begin{array}{c}\text { Pneumococcus } \\
\text { Hem. Staph. aureus } \\
\text { 0 }\end{array}$ & TW & 4 & $\mathbf{0}$ & 4 & 19 & 8 & 128 & $\begin{array}{l}\text { Pen } \\
\text { EM }\end{array}$ & Recov. \\
\hline N. M. & $\begin{array}{l}\text { Sputum } \\
\text { Blood }\end{array}$ & $\underset{0}{\text { Pneumococcus }}$ & TW & 6 & $\mathbf{0}$ & 6 & 13 & 64 & 2,048 & Pen & Recov. \\
\hline A. L. & $\begin{array}{l}\text { Sputum } \\
\text { Blood }\end{array}$ & $\underset{0}{\text { Pneumococcus }}$ & TW & 1 & $\mathbf{0}$ & 1 & 8 & 16 & 256 & Pen & Recov. \\
\hline G. $\mathbf{M}$. & $\begin{array}{l}\text { Sputum } \\
\text { Blood }\end{array}$ & $\begin{array}{c}H . \text { influenzae } \\
0\end{array}$ & TW & 13 & $\mathbf{0}$ & 12 & 30 & 512 & 1,024 & $\underset{\text { SM }}{\text { CM }}$ & Recov. \\
\hline H. W. & $\begin{array}{l}\text { Sputum } \\
\text { Blood }\end{array}$ & Hem. Staph. aureus & TW & 35 & 0 & & 35 & & 512 & $\begin{array}{l}\mathrm{EM} \\
\mathrm{CM} \\
\mathbf{S M}\end{array}$ & Recov. \\
\hline N. C. & $\begin{array}{l}\text { Sputum } \\
\text { Blood }\end{array}$ & $\underset{0}{\text { Pneumococcus }}$ & & & & 19 & 30 & 128 & 64 & $\begin{array}{l}\text { Pen } \\
\text { EM } \\
\text { SM }\end{array}$ & Recov. \\
\hline L. F. & $\begin{array}{l}\text { Sputum } \\
\text { Blood }\end{array}$ & Hem. Staph. aureus & TW & 9 & 0 & 11 & 26 & 256 & 512 & $\begin{array}{l}\text { Pen } \\
\text { EM } \\
\text { SM }\end{array}$ & Recov. \\
\hline A. $\mathbf{M}$. & $\begin{array}{l}\text { Sputum } \\
\text { Blood }\end{array}$ & $\underset{0}{\text { Pneumococcus }}$ & TW & 7 & 0 & 7 & 15 & 128 & 4.096 & Pen & Recov. \\
\hline
\end{tabular}

* TW, Throat washings.
† EM, Erythromycin; Te, Tetracycline; Pen, Penicillin; SM, Streptomycin; CM, Chloramphenicol. 
TABLE IV

Primary influenza virus pneumonia: Summary of clinical data

\begin{tabular}{|c|c|c|c|c|c|c|c|c|c|c|c|}
\hline \multirow{3}{*}{$\begin{array}{l}\text { Patient, } \\
\text { Age, } \\
\text { Sex }\end{array}$} & \multirow[b]{3}{*}{$\begin{array}{c}\text { Date of } \\
\text { admission }\end{array}$} & \multirow{3}{*}{$\begin{array}{l}\text { Under- } \\
\text { lying } \\
\text { disease* }\end{array}$} & \multirow{3}{*}{$\begin{array}{l}\text { Duration } \\
\text { of illness } \\
\text { prior to } \\
\text { pulmonary } \\
\text { symptoms }\end{array}$} & \multicolumn{8}{|c|}{ Pulmonary involvement } \\
\hline & & & & \multicolumn{4}{|c|}{ Symptoms } & \multicolumn{4}{|c|}{ Signs } \\
\hline & & & & Chills & $\begin{array}{c}\text { Productive } \\
\text { cough }\end{array}$ & $\begin{array}{l}\text { Chest } \\
\text { pain }\end{array}$ & Dyspnea & $\begin{array}{c}\text { Resp./ } \\
\text { min. }\end{array}$ & $\begin{array}{c}\text { Admission } \\
\text { temp. }\end{array}$ & $\begin{array}{l}\text { Cya- } \\
\text { nosis }\end{array}$ & $\begin{array}{l}\text { Pulmonary } \\
\text { findings** }\end{array}$ \\
\hline & & & days & & & & & & ${ }^{\circ} \mathrm{C}$. & & \\
\hline$\underset{49}{\text { G. }} \stackrel{\text { H. }}{\mathbf{M}}$ & $10 / 5 / 57$ & $\begin{array}{l}\text { RHD, AF, } \\
\text { MS, MI }\end{array}$ & $<1$ & 0 & $\underset{\text { bloody }}{++}$ & $\mathbf{0}$ & $\underset{\text { severe }}{++}$ & 40 & 40.2 & ++ & $\begin{array}{l}\text { Bilat. basilar } \\
\text { insp. rales }\end{array}$ \\
\hline$\underset{47}{\text { C. }} \stackrel{P}{\dot{M}}$ & $10 / 11 / 57$ & RHD, MI & $<1$ & + & $\underset{\text { mucoid }}{++}$ & 0 & $\underset{\text { severe }}{++}$ & 38 & 39.5 & +++ & $\begin{array}{l}\text { Diffuse bilat. } \\
\text { wheezing. } \\
\text { rales }\end{array}$ \\
\hline A. $\stackrel{\mathrm{B}}{\mathrm{M}}$ & $10 / 13 / 57$ & $\begin{array}{l}\text { RHD, MI, } \\
\text { AS, AI }\end{array}$ & $<1$ & + & $\underset{\text { bloody }}{++}$ & 0 & $\begin{array}{c}+++ \\
\text { severe }\end{array}$ & 36 & 40.0 & +++ & $\begin{array}{l}\text { Diffuse harsh } \\
\text { B.S., Insp. } \\
\text { rales, RLL, } \\
\text { LLL. }\end{array}$ \\
\hline$\underset{45}{\mathrm{P}} \stackrel{\mathrm{B}}{\mathrm{M}}$ & $10 / 14 / 57$ & 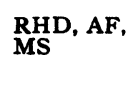 & $<1$ & 0 & $\underset{\text { bloody }}{++}$ & $\mathbf{0}$ & $\underset{\text { severe }}{+++}$ & 42 & 40.4 & +++ & $\begin{array}{l}\text { Diffuse sup-- } \\
\text { pression, B.S.. } \\
\text { rales, RLL, } \\
\text { LLL }\end{array}$ \\
\hline$\underset{75}{\mathrm{~J}} \cdot{ }_{\dot{\mathrm{F}}}^{\mathrm{B}}$ & $10 / 15 / 57$ & HCVD & $<1$ & $?$ & $\underset{\text { bloody }}{++}$ & $?$ & $\underset{\text { severe }}{+++}$ & 54 & 39.2 & +++ & $\begin{array}{l}\text { Diffuse bilat. } \\
\text { wheezing, } \\
\text { rales }\end{array}$ \\
\hline$\underset{66}{A} \stackrel{\text { M }}{C_{1}}$ & $10 / 19 / 57$ & $\begin{array}{l}\text { ASCVD } \\
\text { C.O. }\end{array}$ & $<1$ & + & $\underset{\text { mucoid }}{+}$ & $\mathbf{0}$ & $\underset{\text { severe }}{+++}$ & 40 & 39.4 & ++ & $\begin{array}{l}\text { Harsh B.S. } \\
\text { diffuse bilat. } \\
\text { rales }\end{array}$ \\
\hline
\end{tabular}

* Abbreviations are the same as those used in Table II.

t Where pulmonary symptoms blended with initial influenza symptoms the interval has been listed as $<1$.

f Cough, chest pain, dyspnea and cyanosis graded in severity from 0 to +++ .

strated with the Asian strain of influenza A virus. Seven patients were admitted seven to 35 days after the onset of influenza symptoms. In these seven patients initial complement fixing antibody titers of $1: 128$ or greater were demonstrated. A summary of bacteriologic and virologic data appears in Table III.

\section{Primary influenza virus pneumonia}

Six patients in the present series manifested a diffuse pulmonary syndrome which was believed to represent primary influenza virus infection without secondary bacterial infection.

These patients constituted a relatively uniform group. All six patients had established heart disease. Five of the six were males. Four males between the ages of 45 and 49 years had antecedent rheumatic heart disease. Severe mitral valve disease was present in three, combined mitral and aortic valvular disease in one. A 66 year old male had arteriosclerotic heart disease with a history of two previous myocardial infarctions. The single female, a 75 year old woman, had known hypertensive cardiovascular disease.

Clinical history. In the five patients who gave an adequate clinical history, a remarkably uniform sequence of events had occurred. Each patient had experienced an illness characteristic of influenza with chilly sensations, high fever, scratchy sore throat, a dry, nonproductive cough, headache, muscular aching and prostration. Over the next 24 hours increasing respiratory distress caused each patient to seek hospitalization. Thus each of these patients was admitted within 36 hours of the onset of the initial symptoms of influenza.

In three patients increasing dyspnea was associated with a distressing cough productive of bloody sputum. Three patients had sustained one or more shaking chills. In no instance was pleural pain or purulent sputum noted. Certain clinical features of this illness are summarized in Table IV.

Physical examination. On admission each of these patients appeared acutely and seriously ill. Admission temperatures ranged from 39.2 to $40.4^{\circ} \mathrm{C}$. Respiratory distress was profound with respiratory rates of 36 to 54 per minute. Extreme dyspnea made speech difficult in all instances. Moderate to profound cyanosis was present in all six patients. In none was shock apparent at the time of admission. Venous distention, hepatomegaly and peripheral edema were not present.

Examination of the lungs revealed findings which were quite different from those noted in 
the group with secondary bacterial pneumonia. In general, findings were diffuse, and in no instance were focal signs of consolidation (dullness to percusion, bronchial breath sounds, egophony, bronchophony) detected.

In three patients the only physical findings on admission consisted of fine inspiratory rales accompanied by scattered inspiratory wheezes and expiratory prolongation over the lower lung fields. As the disease progressed, physical findings became more extensive and frequently varied from hour to hour. As dyspnea and cyanosis increased, air exchange became progressively difficult. At times, increasing suppression of breath sounds

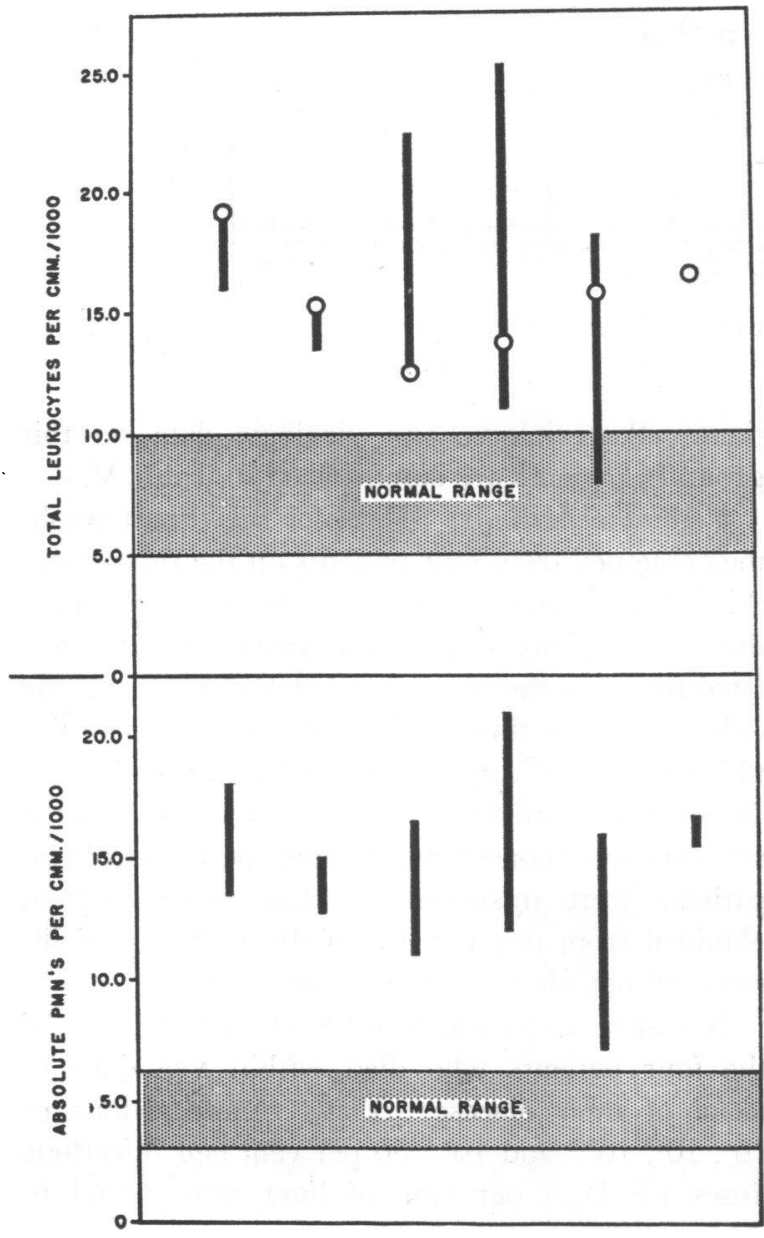

Fig. 3. Total Leukocyte and Polymorphonuclear Leukocyte Counts in Patients with Primary InFLUENZA ViRUS PNEUMonia

Admission white blood cell counts are indicated by the open circles; the vertical bars indicate the range in values during the acute illness. was evident over the lower lung fields posteriorly, spreading gradually to involve the entire chest. At other times, patients were noted to develop increasing expiratory difficulties with diffuse inspiratory rales and prominent expiratory wheezing.

In the terminal stages of the disease, findings on physical examination were similar in all patients. Harsh suppressed breath sounds were heard throughout both lung fields. Generalized sticky inspiratory rales were evident. Coarse bubbling rales and grating rhonchi obscured expiratory breath sounds, and the expiratory phase was markedly prolonged. At this stage dyspnea was unbearable, and respirations were rapid and gasping in nature. Marked agitation was common, and intense cyanosis was observed in all patients.

Routine laboratory studies. Total leukocyte counts on admission ranged from 13,700 to 19,200 cells per cu. mm., and a marked leukocytosis was maintained throughout the acute illness. In every case there was a striking preponderance of polymorphonuclear leukocytes and an increase in immature band forms (Figure 3 ). Erythrocyte sedimentation rates were within normal limits in four of five patients studied. These are depicted in Figure 4 and are contrasted with the elevated sedimentation rates found in the majority of patients with secondary bacterial pneumonia or concomitant viral and bacterial pneumonia.

Chest roentgenograms. Chest roentgenograms revealed diffuse infiltrates which mimicked the roentgenographic picture of cardiac pulmonary edema. In general, a fanning perihilar infiltrate of a diffuse and nodular nature was noted. The infiltrate was more striking toward the lung bases and bronchovascular markings were increased. Two patients showed small loculated interlobar effusions. In one of these patients the effusion was present prior to admission. Typical X-ray pictures are presented in Figures 17, 19, 20 and 21 which accompany the case reports.

Bacteriologic findings. In none of the six patients were significant numbers of pathogenic bacteria isolated from the sputum. Stained smears of sputum revealed only a few polymorphonuclear leukocytes and scant bacteria in three patients. In the remaining three patients polymorphonuclear leukocytes were noted in stained sputum preparations, but only rarely could bacteria be found. One or more sputum and pharyngeal cultures 


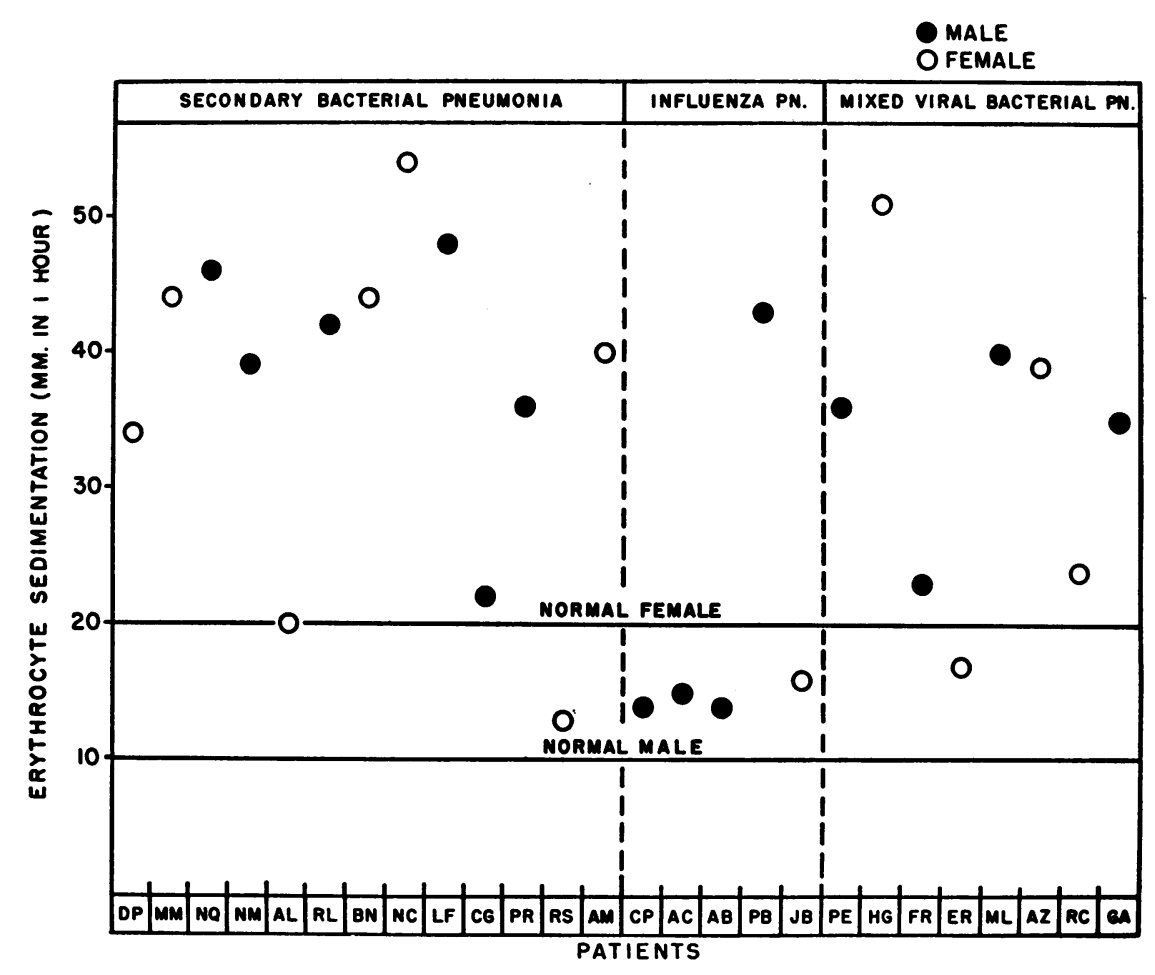

Fig. 4. Admission Erythrocyte Sedimentation Rates (Wintrobe Method) in Patients with Pulmonary Complications of Influenza

taken prior to the institution of therapy demonstrated only normal throat inhabitants (alpha and gamma strepococci, Neisseria and diptheroids) in two patients. An occasional colony of pneumococci was noted in sputum cultures obtained from four patients but normal flora predominated. A few colonies of Hemophilus influenzae were also isolated from the sputum from two of these four patients.

Mice injected with sputum remained healthy, and bacteria could not be isolated on subsequent culture of the peritoneal cavities. Blood cultures taken on one or more occasions from each patient were sterile.

Extensive bacteriologic studies were performed on emulsions of lung tissue obtained from the five patients who died. Multiple cultures from four patients were sterile on incubation for 10 days. The fifth patient dying on the eleventh day of illness had a clear-cut episode of aspiration two days before death. Fungi and bacteria could be seen on microscopic section surrounding aspirated food and muscle fibers within the bronchi. Moderate numbers of Candida albicans and Escherichia coli were obtained on lung cultures from this pa- tient. Bacteriologic and virologic data on this group of patients are summarized in Table V.

Virologic findings. Three of the throat washings obtained from four patients on the second and third day of illness yielded the Asian strain of influenza A virus. Influenza virus was not isolated from the throat washing of Patient P. B., the only patient in this group who survived. A significant rise in complement fixing antibody was demonstrated in this patient. Attempts at virus recovery from concentrated urine specimens of two patients were unsuccessful. Cerebrospinal fluid obtained from one patient on the fifth day of illness did not yield influenza virus.

Influenza virus was isolated from the lungs of the four patients who died within five days of onset of their disease. Virus concentrations of $10^{2}, 10^{4}, 10^{5.3}$ and $10^{5.7} 50$ per cent egg infectious doses $\left(\mathrm{EID}_{50}\right)$ per $\mathrm{Gm}$. of lung were found in these specimens (Table V).

\section{Combined influenza virus and bacterial pneu- monia}

Nine patients in the present series had an illness accompanied by clinical and laboratory fea- 
THE PULMONARY COMPLICATIONS OF INFLUENZA

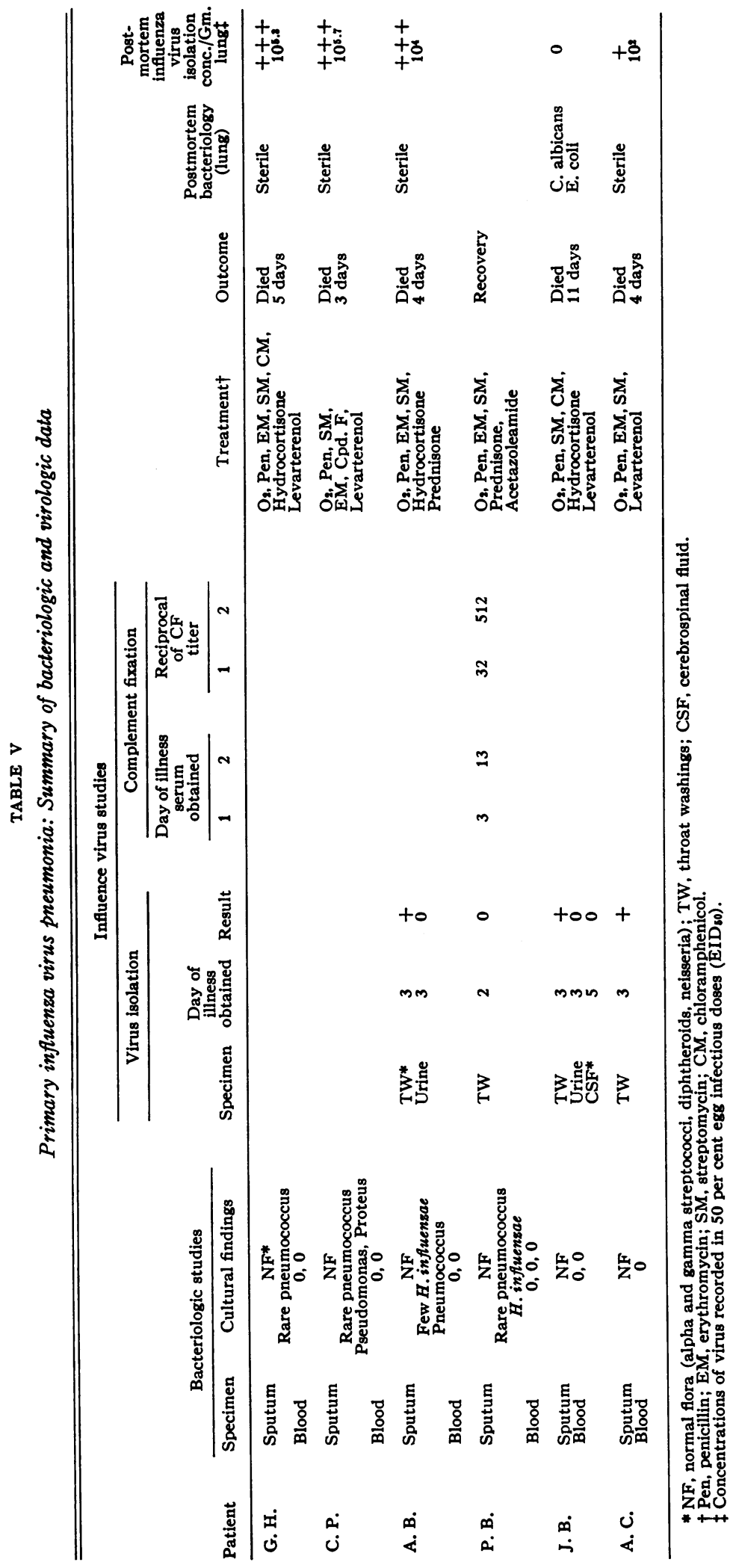


tures which suggested that both influenza virus and specific bacterial pathogens were responsible for their lower respiratory tract disease. These patients ranged in age from 21 to 61 years. Four were males and five were females. There was evidence of antecedent chronic disease in six. Three patients had rheumatic heart disease with mitral valve involvement; one of these three patients was also in the sixth month of pregnancy. Two patients had arteriosclerotic cardiovascular disease with previously documented myocardial infarctions. One patient had multiple myeloma. One of the three patients without evidence of underlying disease was in the eighth month of pregnancy.

Clinical history. Eight patients in whom a reliable history could be obtained gave a story of typical influenza. Four patients noted a period of improvement lasting two to four days before symptoms suggesting lower respiratory tract infection appeared. In four patients the symptoms of lower pulmonary tract disease blended with the original influenzal symptoms, and it was impossible to determine the point at which the pulmonary involvement had occurred. Severe dyspnea similar to that noted by patients with the syndrome of primary influenza virus pneumonia caused the admission of each patient.

Seven patients had noted cough which was productive of grossly bloody sputum in four and was purulent in three. Shaking chills were noted by five patients. Four patients noted pleuritic chest pain.

Physical findings. All nine patients appeared seriously ill at the time of admission. Admission temperatures ranged from 38.6 to $40.4^{\circ} \mathrm{C}$. Severe respiratory distress was present in all, and respiratory rates above 36 respirations per minute were present in seven individuals. Cyanosis was noted in eight patients. Two patients with preexisting heart disease showed signs of congestive failure. In the remaining seven patients, no venous distention or other signs of cardiac failure were noted.

Examination of the lungs revealed variable

TABLE VI

Concomitant influenza virus and bacterial pneumonia: Summary of clinical data

\begin{tabular}{|c|c|c|c|c|c|c|c|c|c|c|c|}
\hline \multirow{3}{*}{$\begin{array}{l}\text { Patient, } \\
\text { Age, } \\
\text { Sex }\end{array}$} & \multirow{3}{*}{$\begin{array}{c}\text { Date } \\
\text { of } \\
\text { admission }\end{array}$} & \multirow{3}{*}{$\begin{array}{l}\text { Under- } \\
\text { lying } \\
\text { disease* }\end{array}$} & \multirow{3}{*}{$\begin{array}{l}\text { Duration } \\
\text { of illness } \\
\text { prior to } \\
\text { pulmonary } \\
\text { symptoms }\end{array}$} & \multicolumn{8}{|c|}{ Pulmonary involvement $\ddagger$} \\
\hline & & & & \multicolumn{4}{|c|}{ Symptoms } & \multicolumn{4}{|c|}{ Signs } \\
\hline & & & & Chills & $\begin{array}{l}\text { Productive } \\
\text { cough }\end{array}$ & $\begin{array}{l}\text { Chest } \\
\text { pain }\end{array}$ & Dyspnea & $\begin{array}{l}\text { Resp./ } \\
\text { min. }\end{array}$ & $\begin{array}{l}\text { Admission } \\
\text { temp. }\end{array}$ & $\begin{array}{l}\text { Cya- } \\
\text { nosis }\end{array}$ & $\begin{array}{l}\text { Pulmonary } \\
\text { findings* }\end{array}$ \\
\hline & & & days & & & & & & ${ }^{\circ} \mathrm{C}$. & & \\
\hline H. G. & $10 / 11 / 57$ & $\begin{array}{c}0 \\
\text { (pregnant } \\
8 \text { mos.) }\end{array}$ & 4 & + & $\stackrel{+}{+}$ & + & $\underset{\text { severe }}{+++}$ & 60 & 38.6 & ++ & $\begin{array}{l}\text { Consol., RLL } \\
\text { Diffuse insp. rales }\end{array}$ \\
\hline 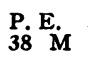 & $10 / 15 / 57$ & $\begin{array}{l}\text { RHD, } \\
\text { MS, MI, } \\
\text { AS, AI }\end{array}$ & 1 & + & $\stackrel{+}{+}$ & $\mathbf{0}$ & $\underset{\text { severe }}{+++}$ & 44 & 39.5 & ++ & $\begin{array}{l}\text { Consol., RLL } \\
\text { Diffuse wheeze, } \\
\text { harsh B.S. }\end{array}$ \\
\hline$\underset{35}{\mathrm{E}} \underset{\mathrm{F}}{\mathrm{R}}$ & $10 / 17 / 57$ & $\begin{array}{c}\text { RHD, MS } \\
\text { (pregnant } \\
6 \text { mos.) }\end{array}$ & 1 & + & $\underset{\text { bloody }}{+}$ & + & ++ & 44 & 39.8 & + & Consol., LLL \\
\hline$\underset{57}{\mathrm{G}} \stackrel{\mathrm{A}}{\mathrm{M}}$ & $10 / 18 / 57$ & $\begin{array}{l}\text { ASCVD } \\
\text { old C.O. }\end{array}$ & 1 & + & $\stackrel{+}{+}$ & $\mathbf{0}$ & ++ & 34 & 39 & $\mathbf{0}$ & $\begin{array}{l}\text { Bilat. basilar } \\
\text { rales }\end{array}$ \\
\hline$\underset{31}{R} \underset{F}{\text { C. }}$ & $10 / 23 / 57$ & RHD, MS & 2 & + & $\underset{\text { purulent }}{+}$ & + & ++ & 28 & 40 & + & $\begin{array}{l}\text { Consol., RML } \\
\text { Insp. rales, } \\
\text { RLL, LLL }\end{array}$ \\
\hline $\begin{array}{l}\text { M. L. } \\
\text { (M) }\end{array}$ & $10 / 24 / 57$ & $\begin{array}{l}\text { ASCVD } \\
\text { old C.O. }\end{array}$ & 1 & $\mathbf{0}$ & $\underset{\substack{\text { muco } \\
\text { purulent }}}{+}$ & $\mathbf{0}$ & $\underset{\text { severe }}{+++}$ & 40 & 39.6 & + & $\begin{array}{l}\text { Diffuse insp., } \\
\text { exp. rales }\end{array}$ \\
\hline$\underset{53}{\mathrm{~F}} \stackrel{\mathrm{R}}{\mathrm{M}}$ & $10 / 28 / 57$ & $\begin{array}{l}\text { Multiple } \\
\text { myeloma }\end{array}$ & $\stackrel{?}{1-4}$ & & Unreliable & e history & & 38 & 39.2 & $+t+$ & Rales, RLL, LLL \\
\hline A. $Z_{\text {F }}$ & $11 / 8 / 57$ & $\mathbf{0}$ & 3 & $\mathbf{0}$ & $\begin{array}{c}+ \\
\text { sanguino } \\
\text { purulent }\end{array}$ & ++ & $\underset{\text { severe }}{++t}$ & 60 & 40.3 & +++ & $\begin{array}{l}\text { Consol., RLL, } \\
\text { LLL } \\
\text { Diffuse rales, } \\
\text { wheezes, harsh } \\
\text { B.S. }\end{array}$ \\
\hline$\underset{6 i}{B} \dot{F}$ & $1 / 26 / 58$ & $\mathbf{0}$ & 3 & $\mathbf{0}$ & $\stackrel{++}{\text { bloody }}$ & 0 & $\underset{\text { severe }}{+++}$ & 60 & 40.4 & $+t+$ & $\begin{array}{l}\text { Consol., LLL } \\
\text { Diffuse rales, } \\
\text { wheezes, rhonchi }\end{array}$ \\
\hline
\end{tabular}

* Abbreviations are the same as those used in Table II.

* Where pulmonary symptoms blended with initial influenza symptoms the interval has been listed as $<1$. 
findings. Six patients had evidence of local consolidation of one or more lobes. Five of these patients had, in addition, diffuse signs which included inspiratory rales, prolongation of expiration, wheezing and diminished or harsh breath sounds. These findings were similar to the pulmonary findings noted in the patients described previously with primary influenza virus pneumonia. Three patients had diffuse pulmonary findings without signs of focal consolidation. Clinical data are summarized in Table VI.

Routine laboratory studies. Total leukocyte counts obtained on admission ranged from 1,400 to 21,000 leukocytes per cu. $\mathrm{mm}$. Six of the nine patients showed a marked leukocytosis with an increase in immature leukocytes. Two patients showed a striking leukopenia and granulocytopenia. In both of these patients Staphylococcus aureus was the bacterial pathogen and both subsequently died of their illness. Total leukocyte and polymorphonuclear leukocyte counts obtained during the course of the acute illness are pictured in Figure 5. Erythrocyte sedimentation rates ranged from 17 to $51 \mathrm{~mm}$. per hour (Figure 3), and were significantly elevated in five patients.

Chest roentgenograms. Seven patients showed both local lobar infiltrates and bilateral nodular perihilar infiltrates on admission chest roentgenograms. Diffuse perihilar infiltrates similar to those seen in the group believed to have primary influenza virus pneumonia were observed in two patients. Typical roentgenograms are pictured in Figures $24,26,27$ and 29 which accompany the case histories.

Bacteriologic findings. Examination of sputum smears obtained on admission commonly revealed large numbers of polymorphonuclear leukocytes, even in patients with leukopenia. Large numbers of microorganisms could be seen in sputum smears. On sputum culture, coagulase positive Staphylococcus aureus was isolated in pure culture from three patients. Pneumococci in relatively pure culture were isolated from three. Sputum cultures resulted in growth of both pneumococci and hemolytic Staphylococcus aureus in three instances. A few colonies of $\mathrm{He}$ mophilus influenzae were isolated from the sputum culture of one patient in addition to staphylococci and pneumococci. Repeated blood cultures were sterile in all patients. Postmortem cultures

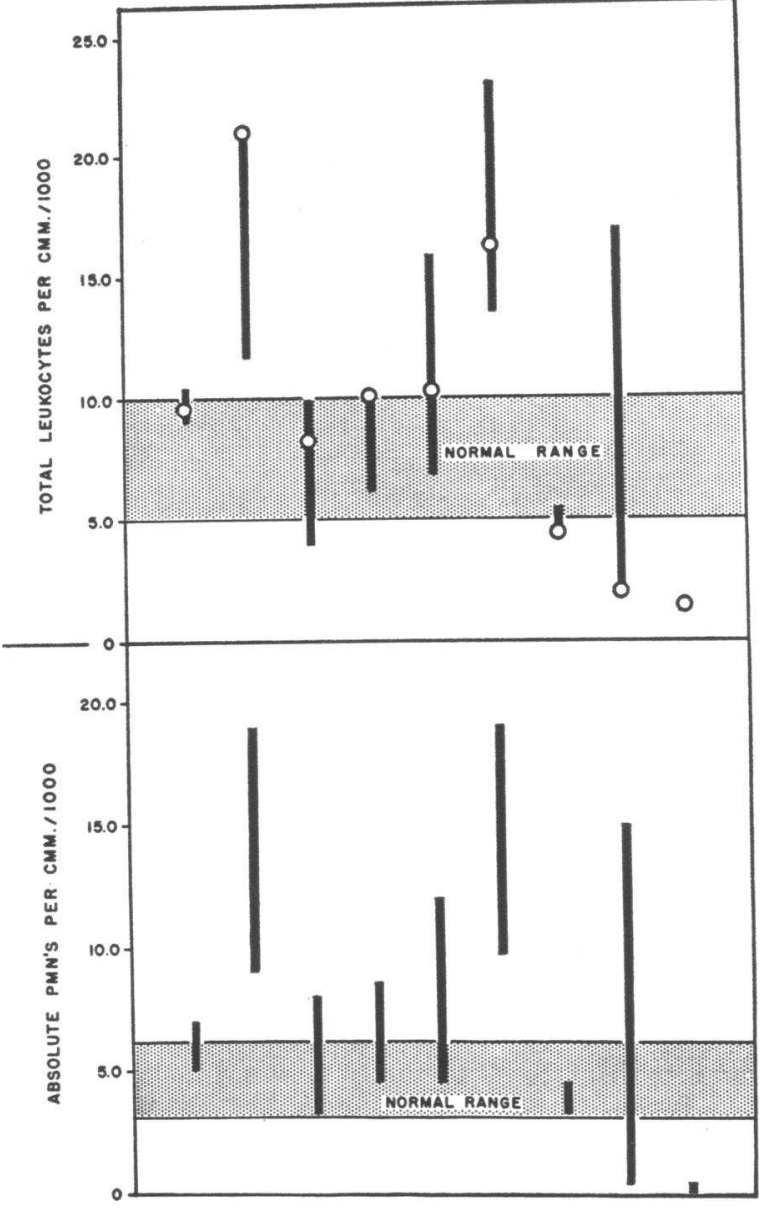

Fig. 5. Total Leukocyte and Polymorphonuclear Leukocyte Counts in Patients with Concomitant Influenza Virus and Bacterial Pneumonia

Admission white blood cell counts are indicated by the open circles; the vertical bars indicate the range in values during the acute illness.

were obtained on all four patients who died. Lung emulsions from two patients yielded coagulase positive staphylococci in concentrations of $10^{8}$ microorganisms per $\mathrm{ml}$. The lungs of one patient dying 53 days after the onset of influenza with an unusual myocarditis and pulmonary arteritis showed a few colonies of coagulase positive staphylococci, Candida albicans and E. coli, but there was no histologic evidence of significant bacterial infection. Specimens of lung obtained from one patient dying on the sixth hospital day were sterile on culture. This patient had had large numbers of pneumococci isolated from initial sputum cultures.

Virologic studies. Influenza A virus of the 
LOURIA, BLUMENFELD, ELLIS, KILBOURNE, AND ROGERS

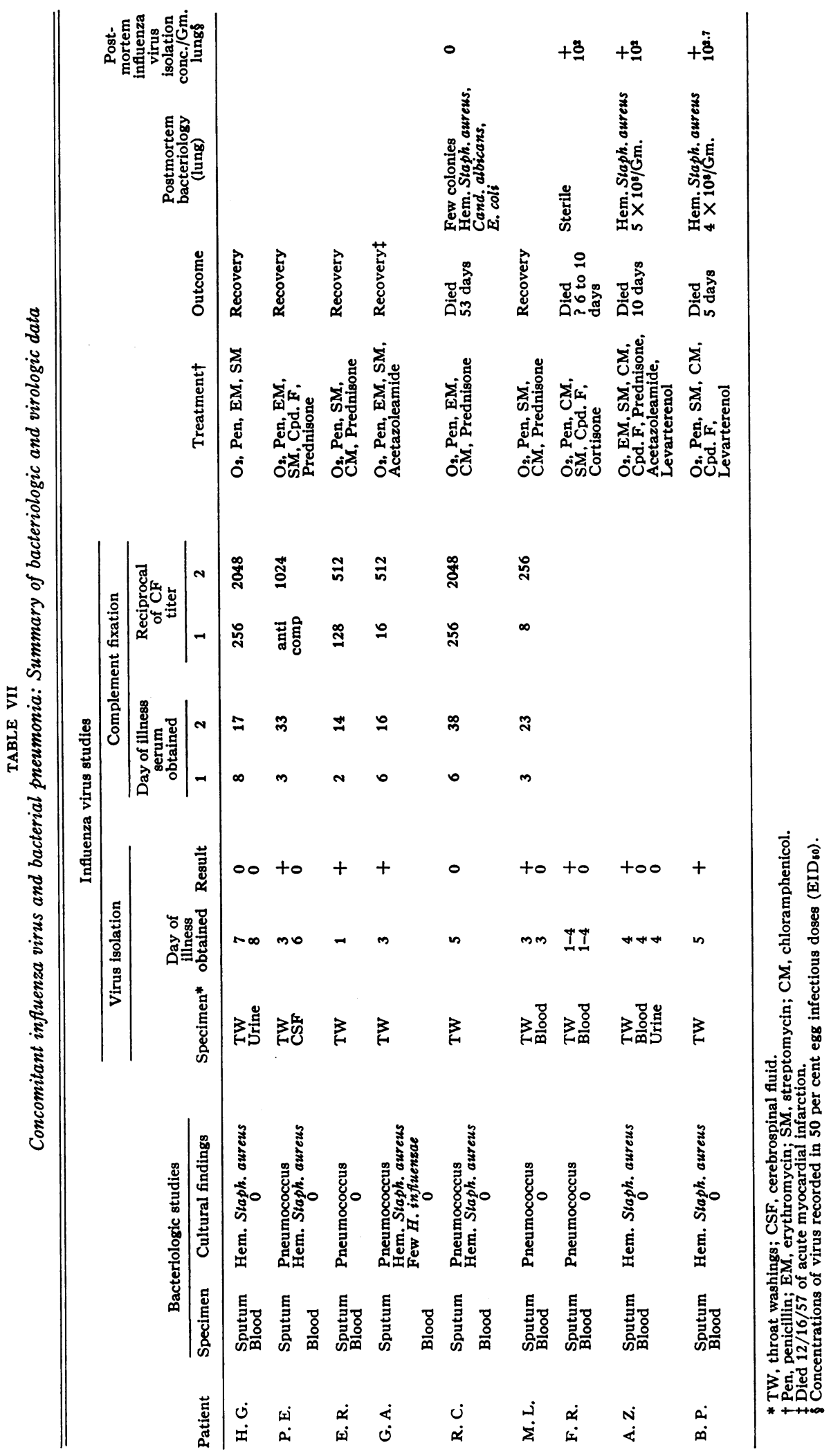


Asian strain was recovered from seven of nine patients in whom throat washings were obtained prior to the fourth day of illness. The two throat washings negative for influenza virus were obtained on the fifth and seventh days of disease.

Blood specimens obtained from three patients were inoculated into chick embryos without recovery of influenza virus. Concentrated urine specimens from two patients and one cerebrospinal fluid obtained on the sixth day of illness from a patient manifesting central nervous system signs likewise failed to yield influenza virus (7).

Paired serologic specimens obtained on six patients showed a fourfold or greater increase in complement fixing antibody to the Japan strain of influenza A virus.

At autopsy, low titers of influenza virus were demonstrated in the lungs of three patients, all of whom died prior to the ninth day of their illness. No influenza virus was recovered from the patient who died 53 days after the onset of influenza. Bacteriologic and virologic data on these cases are summarized in Table VII.

\section{Special studies performed on patients with in- fluenza and pneumonia}

\section{Cardiac studies}

Many patients in the current series had evidence of underlying heart disease. Because of this high incidence of pre-existing cardiac abnormalities, and reports of myocarditis associated with influenza $(15,16)$, a careful evaluation of cardiac function was made in all patients. Thirteen of the 15 patients with localized secondary bacterial pneumonia had no clinical or laboratory findings suggestive of cardiac involvement. The two remaining patients had severe rheumatic heart disease, and evidence of congestive heart failure accompanied their pneumonia. Dyspnea, orthopnea and moderately elevated venous pressures of 140 and $165 \mathrm{~mm}$. saline were noted in these two patients.

In contrast, all of the patients who presented the diffuse pulmonary syndromes with either primary influenza virus pneumonia or combined bacterial and viral pneumonia showed striking dyspnea, orthopnea and cyanosis. Pulmonary findings were usually compatible with left heart failure. There were, however, certain features which suggested that the acute pulmonary disease observed was secondary to pulmonary infection rather than cardiac failure:

$a$. First, the high fever, leukocytosis and profound systemic symptoms suggested that an acute infectious process was present.

$b$. Second, cardiac findings suggesting serious myocardial involvement, such as heart sounds of poor quality, diastolic gallop, pulsus alternans or narrowing pulse pressure, were not observed.

c. Third, signs of right heart failure were consistently absent in 13 of the 15 patients with diffuse pulmonary syndromes, despite the presence of significant pre-existing heart disease in 11 of these patients. Venous pressure determinations were transiently elevated $(120 \mathrm{~mm}$. and $150 \mathrm{~mm}$. saline) in two patients who were agitated at the time of study. The remaining venous pressures in these 13 patients were consistently normal. Two patients with concomitant influenza virus and bacterial pneumonia had definite signs of congestive heart failure which included peripheral edema, distended neck veins, hepatomegaly and elevated venous pressures. A summary of venous pressure determinations is recorded in Figure 6.

d. Blood volume studies. Determinations of blood and plasma volume were made on four patients at the height of their disease process. Blood volumes and plasma volumes were within predicted normal limits in three patients. A minimally elevated blood volume (118 per cent) was noted in one patient. Because of evidence of progressive fluid accumulation in the lungs, T-1824 disappearance curves were also performed on two of these patients in an attempt to detect whether a generalized increase in vascular permeability was present. In both instances disappearance curves were normal. These data are summarized in Table VIII.

e. Electrocardiographic studies. Electrocardiograms were obtained on one or more occasions in 12 of 15 patients with secondary bacterial pneumonia. In four instances, electrocardiographic abnormalities were noted. Three patients with rheumatic heart disease showed electrocardiographic changes compatible with their underlying cardiac lesions without other abnormalities. One patient, a 72 year old male with mild diabetes, showed abnormal $\mathrm{T}$ waves and $\mathrm{RT}$ segments suggestive of 


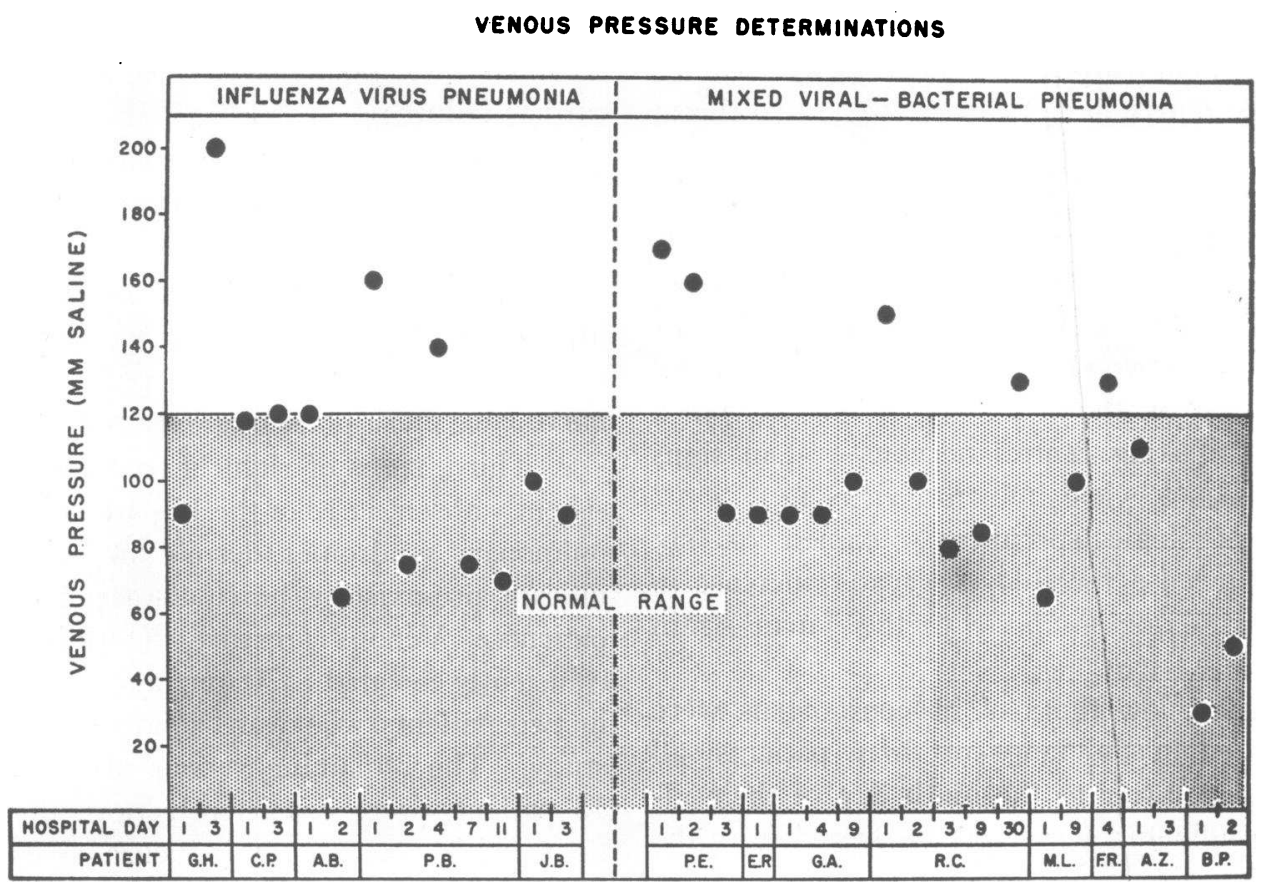

Fig. 6. Venous Pressure Determinations in Patients with Primary Influenza or Virus Pneumonia, Concomitant Influenza Virus and Bacterial Pneumonia

Pressures recorded in $\mathrm{mm}$. saline above the level of the right auricle.

coronary artery disease. No changes suggestive of myocarditis were noted.

Serial electrocardiograms were obtained on 14 of the 15 patients with diffuse pulmonary involvement. One patient without previous known heart disease (B. P.) showed electrocardiographic changes suggesting early left ventricular hypertrophy. Patients with underlying heart disease showed electrocardiographic abnormalities compatible with their basic heart disease. These abnormalities persisted without change throughout the course of illness. One patient with rheumatic heart disease (C. P.) had bouts of ventricular tachycardia a few hours preceding death. The remaining patients without antecedent heart disease had normal electrocardiograms. Again,

TABLE VIII

Blood volume studies and T-1824 disappearance rates in four patients with pneumonia complicating influenza *

\begin{tabular}{|c|c|c|c|c|c|c|c|c|c|}
\hline $\begin{array}{l}\text { Patient, } \\
\text { Age, } \\
\text { Sex }\end{array}$ & $\begin{array}{c}\text { Type of } \\
\text { pneumonia }\end{array}$ & $\begin{array}{l}\text { Day of } \\
\text { illness }\end{array}$ & $\begin{array}{l}\text { Plasma } \\
\text { volume }\end{array}$ & $\begin{array}{l}\text { Predicted } \\
\text { plasma } \\
\text { volume }\end{array}$ & $\begin{array}{l}\text { Plasma } \\
\text { vol. } \\
\text { as \% of } \\
\text { predicted } \\
\text { norm. }\end{array}$ & $\underset{\text { tocrit } \dagger}{\text { Hema- }}$ & $\begin{array}{c}\text { Blood } \\
\text { volume }\end{array}$ & $\begin{array}{l}\text { Blood } \\
\text { vol. } \\
\text { as \% of } \\
\text { predicted } \\
\text { norm. }\end{array}$ & $\begin{array}{c}\text { T-1824 } \\
\text { disappearance } \\
\text { (\% in 1st hour) } \ddagger\end{array}$ \\
\hline${ }_{45}^{A} B_{\text {M }}$ & Primary virus & 3 & $\begin{array}{c}L . \\
3.20\end{array}$ & $\begin{array}{l}L . \\
3.11\end{array}$ & 103 & $\begin{array}{l}\% \\
40\end{array}$ & $\begin{array}{l}L . \\
5.34\end{array}$ & 95 & \\
\hline${ }_{45}^{P} B_{M}$ & Primary virus & 2 & 3.33 & 3.26 & 102 & 40.1 & 5.56 & 95.1 & 5.84 \\
\hline${ }_{75}{ }_{5}$ F & Primary virus & 3 & 2.89 & 2.54 & 114 & 39.6 & 4.78 & 118 & 4.45 \\
\hline${ }_{38}$ E. $_{M}$ & $\begin{array}{l}\text { Mixed } \\
\text { viral-bacterial }\end{array}$ & $\begin{array}{l}2 \\
3\end{array}$ & $\begin{array}{l}3.34 \\
3.51\end{array}$ & $\begin{array}{l}3.15 \\
3.15\end{array}$ & $\begin{array}{l}106 \\
111\end{array}$ & $\begin{array}{l}45.6 \\
39.5\end{array}$ & $\begin{array}{l}6.13 \\
5.80\end{array}$ & $\begin{array}{l}108 \\
102\end{array}$ & \\
\hline
\end{tabular}

*T-1824 technique (11).

† Corrected for 4 per cent trapped plasma.

$\ddagger$ Average T-1824 disappearance in normal males, 5.2 per cent \pm 1.65 (12). 
TABLE IX

Blood gas data on eight patients with influenza virus pneumonia or combined influenza virus and bacterial pneumonia

\begin{tabular}{|c|c|c|c|c|c|c|c|c|}
\hline \multirow{2}{*}{$\begin{array}{l}\text { Patient, } \\
\text { Age, } \\
\text { Sex, } \\
\text { Under- } \\
\text { lying } \\
\text { disease* } \\
\end{array}$} & \multirow[b]{2}{*}{$\begin{array}{c}\text { Day } \\
\text { of } \\
\text { illness }\end{array}$} & \multirow[b]{2}{*}{ Status of disease } & \multirow[b]{2}{*}{ Conditions of test } & \multicolumn{5}{|c|}{ Arterial blood gas studies } \\
\hline & & & & $\underset{\text { units }}{\text { pH }}$ & $\begin{array}{c}\text { Os sat. } \\
\%\end{array}$ & $\underset{m m . H_{g}}{\mathrm{pCO}_{2}}$ & $\begin{array}{c}\mathrm{CO}_{2} \\
\text { content } \\
m M / L\end{array}$ & $\underset{m E q . I L}{H C O}$ \\
\hline \multicolumn{9}{|c|}{ Primary influenza virus pneumonia } \\
\hline \multirow{6}{*}{$\begin{array}{c}\text { P. B. } \\
\text { 45 M } \\
\text { RHD } \\
\text { MS-MI }\end{array}$} & 3 & $\begin{array}{l}\text { Day of admission, critically } \\
\text { ill, cyanotic, tachypneic }\end{array}$ & Off $\mathrm{O}_{2}$ & 7.43 & 84.8 & 45 & 30.3 & 28.9 \\
\hline & 4 & $\begin{array}{l}\text { Apparent improvement, } \\
\text { less respiratory distress }\end{array}$ & $\mathrm{Off}_{2}$ & 7.41 & 91.8 & 51 & 33.2 & 31.7 \\
\hline & 5 & $\begin{array}{l}\text { Condition deteriorating, } \\
\text { increasing respiratory distress }\end{array}$ & $\begin{array}{l}\text { IPPBt } \\
100 \% \mathrm{O}_{2}\end{array}$ & 7.25 & 92.8 & 51 & 23.06 & 21.6 \\
\hline & 6 & No significant change & Off $\mathrm{O}_{2}$ & 7.31 & 83.8 & 76 & 39.43 & 37.2 \\
\hline & 7 & $\begin{array}{l}\text { Initial improvement, } \\
\text { beginning diuresis }\end{array}$ & $\begin{array}{c}\text { IPPB } \\
100 \% \mathrm{O}_{2} \\
4 \text { hours post acetazoleamide }\end{array}$ & $7.38(v) \ddagger$ & & 538 & & \\
\hline & 8 & $\begin{array}{l}\text { Marked diuresis, } \\
\text { improvement }\end{array}$ & $\begin{array}{c}\text { Off } \mathrm{O}_{2} \\
\text { Acetazoleamide, } 1 \mathrm{Gm} \text {. daily }\end{array}$ & 7.30 & 92.9 & 47 & 23.62 & 22.61 \\
\hline \multirow[t]{8}{*}{$\underset{\text { HCVD }}{75} \underset{\text { J. }}{\stackrel{B}{F}}$} & 3 & $\begin{array}{l}\text { Day after admission, coma- } \\
\text { tose, tachypneic, cyanotic }\end{array}$ & Off $\mathrm{O}_{2}$ & 7.21 & 46.2 & 67 & 28 & 26 \\
\hline & 3 & 30 minutes later & $\begin{array}{c}\text { Positive pressure mask } \\
100 \% \mathrm{O}_{2}\end{array}$ & 7.16 & 91.0 & 76 & 28.7 & 26.4 \\
\hline & 3 & 30 minutes later & $\begin{array}{c}\text { IPPB } \\
100 \% \mathrm{O}_{2}\end{array}$ & 7.25 & 96.5 & 47 & 21.6 & 20.2 \\
\hline & 4 & $\begin{array}{l}\text { Coma lighter, } \\
\text { respirations less labored }\end{array}$ & Off $\mathrm{O}_{2}$ & 7.36 & 73.5 & 39 & 22.4 & 21.2 \\
\hline & 4 & 30 minutes later & $\underset{100 \% \mathrm{O}_{2}}{\mathrm{IPPB}}$ & 7.23 & 91.5 & 54 & 23.6 & 21.9 \\
\hline & 5 & Same as day 4 & Off $\mathrm{O}_{2}$ & 7.14 & 69.9 & 60 & 22 & 20.1 \\
\hline & 5 & 30 minutes later & $\begin{array}{l}\text { IPPB } \\
40 \% \mathrm{O}_{2}\end{array}$ & 7.13 & 94.7 & 63 & 22.4 & 20.6 \\
\hline & 8 & $\begin{array}{l}\text { Slight improvement, lungs } \\
\text { clearing, coma continuing }\end{array}$ & $\mathrm{Off} \mathrm{O}_{2}$ & 7.34 & 74.2 & 37 & 20.6 & 19.5 \\
\hline \multicolumn{9}{|c|}{ Concomitant influenza and bacterial pneumonia } \\
\hline \multirow{5}{*}{$\begin{array}{c}\text { P. E. } \\
\text { 38 } \\
\text { RHD } \\
\text { MS-MI } \\
\text { AS-AI }\end{array}$} & 3 & $\begin{array}{l}\text { Day after admission, critically } \\
\text { ill, cyanotic, tachypneic }\end{array}$ & Off $\mathrm{O}_{2}$ & 7.46 & 80.1 & 37 & 26.8 & 25.7 \\
\hline & 4 & No change & $\begin{array}{l}\text { IPPB } \\
100 \% \mathrm{O}_{2}\end{array}$ & 7.40 & 87.7 & 46.4 & 29.3 & 27.9 \\
\hline & 8 & Steady improvement & $\mathrm{Off}_{2}$ & 7.48 & 85.4 & 42.0 & 31.0 & 29.7 \\
\hline & 13 & Steady improvement & $\mathrm{Off}_{2}$ & 7.38 & 92.6 & 46.0 & 27.7 & 26.3 \\
\hline & 16 & Steady improvement & Off $\mathrm{O}_{2}$ & 7.36 & 92.2 & 52.0 & 30.0 & 28.4 \\
\hline \multirow[t]{5}{*}{ A. Z. } & 4 & $\begin{array}{l}\text { Day of admission, critically } \\
\text { ill, cyanotic, tachypneic }\end{array}$ & Off $\mathrm{O}_{2}$ & 7.42 & 71.1 & 25 & 16.8 & 16.1 \\
\hline & 4 & 30 minutes later & $\begin{array}{l}\text { Positive pressure mask } \\
100 \% \mathrm{O}_{2}\end{array}$ & 7.40 & 82.6 & 28 & 17.5 & 16.7 \\
\hline & 4 & 30 minutes later & $\begin{array}{l}\text { IPPB } \\
100 \% \mathrm{O}_{2}\end{array}$ & 7.36 & 93.9 & 34 & 19.4 & 18.5 \\
\hline & 8 & $\begin{array}{l}\text { Semi comatose, } \\
\text { obstructive respirations }\end{array}$ & $\begin{array}{c}\text { IPPB } \\
100 \% \mathrm{O}_{2}\end{array}$ & 7.22 & 97.2 & 78 & 33.2 & 30.8 \\
\hline & 9 & $\begin{array}{l}\text { Comatose, } \\
\text { obstructive respirations }\end{array}$ & $\begin{array}{c}\text { IPPB } \\
100 \% \mathrm{O}_{2} \\
\text { Post acetazoleamide }\end{array}$ & 7.44 & 97 & 39 & 27.1 & 25.9 \\
\hline \multirow{2}{*}{$\begin{array}{c}\text { F. R. } \\
\mathbf{5 3} \text { M } \\
\text { Multiple } \\
\text { myeloma }\end{array}$} & ? 5-9 & $\begin{array}{l}\text { Increasing respiratory distress, } \\
\text { cyanosis }\end{array}$ & Off $\mathrm{O}_{2}$ & 7.25 & 50.5 & 58 & 26.4 & 24.6 \\
\hline & ? 5-9 & 30 minutes later & $\underset{100 \% \mathrm{O}_{2}}{\text { IPPB }}$ & 7.23 & 91.5 & 62 & 27.0 & 25.0 \\
\hline \multirow[t]{2}{*}{$\begin{array}{l}\text { M. L } \\
\text { G6 } \frac{\mathrm{M}}{\mathrm{MSCVD}}\end{array}$} & 3 & $\begin{array}{l}\text { Day of admission, critically } \\
\text { ill, cyanotic, tachypneic }\end{array}$ & Off $\mathrm{O}_{2}$ & $7.28(v) \ddagger$ & 80.3 & 418 & 20.88 & 19.68 \\
\hline & 7 & Moderate improvement & Off $\mathrm{O}_{3}$ & 7.45 & 90.0 & 37 & 25.0 & 26.1 \\
\hline$\underset{61}{\text { B. }} \mathbf{P}$. & 5 & $\begin{array}{l}\text { Day after admission, critically } \\
\text { ill, cyanotic, tachypneic }\end{array}$ & Off $\mathrm{O}_{2}$ & 7.18 & 70.5 & 27 & 10.5 & 9.6 \\
\hline $\begin{array}{l}\text { G. A. } \\
\text { 57 } \mathbf{M} \\
\text { ASCVD }\end{array}$ & 11 & $\begin{array}{l}\text { Improving, respiratory } \\
\text { distress disappearing }\end{array}$ & $\mathrm{Off}_{\mathbf{2}}$ & $7.23(v) \ddagger$ & 93 & 55.18 & 23.18 & 23.48 \\
\hline
\end{tabular}

* Abbreviations the same as those used in Table II.

* Appreviations the same as those used in Table II.

(v), Value obtained on venous blood.
Calculated from venous $\mathrm{pH}$. 
changes suggestive of myocarditis were not observed.

\section{Blood gas analysis}

Arterial blood gas studies were performed on two patients with primary influenza virus pneumonia and six patients with the syndrome believed to represent combined bacterial and virus pneumonia. The results of these determinations are recorded in Table IX.

Six patients were studied early in the course of their illness. All six showed striking reduction in oxyhemoglobin saturation with values ranging from 46.2 to 84.8 per cent. The two patients with the syndrome of influenza virus pneumonia had elevated partial pressures of carbon dioxide and lowered arterial $\mathrm{pH}$. The four patients with mixed viral and bacterial pneumonias had normal or reduced partial pressures of carbon dioxide and serum bicarbonate concentrations early in the course of the disease, with variable alterations in arterial $\mathrm{pH}$.

As their pulmonary disease progressed, the arterial blood gas studies performed on four patients showed remarkably similar abnormalities. Arterial oxyhemoglobin saturation fell progressively, and values of 50.5 and 69.9 per cent were noted in two patients. The remaining two patients were not removed from oxygen for blood gas studies because of profound air hunger and cyanosis. All four patients developed respiratory acidosis as evidenced by a high partial pressure of carbon dioxide and a markedly reduced arterial $\mathrm{pH}$.

Arterial blood specimens obtained from four patients early in the recovery phase showed a return of the oxyhemoglobin saturation towards normal. Three of these four demonstrated continuing carbon dioxide retention during this period of improvement.

\section{Studies on renal function}

Although urine abnormalities were noted in the majority of patients studied, there was no evidence of direct renal damage accompanying influenza. Proteinuria was present in virtually all patients and appeared to be related to the height of the fever. Hematuria was not noted during the course of illness. Admission blood urea nitrogen values ranged from 11 to $20 \mathrm{mg}$. per cent. In patients with secondary bacterial pneumonia, blood urea nitrogen concentrations promptly returned to normal levels with hydration. In patients critically ill with diffuse pulmonary syndromes, blood urea nitrogen frequently rose as the disease progressed. Urea clearances performed in a number of patients were within normal limits unless shock had supervened. Inulin clearances performed on three patients critically ill with advanced influenza virus pneumonia were significantly depressed.

\section{Studies of serum electrolytes}

No consistent changes in serum electrolytes were noted. In general, serum sodium, potassium and chloride determinations were normal. In patients with diffuse pulmonary disease, venous carbon dioxide combining powers frequently rose as the severity of the illness increased, and serum chlorides fell concomitantly. Two patients with primary influenza virus pneumonia and severe acidosis had elevated serum pyruvate levels of 130 and $164 \mu \mathrm{Eq}$. per L. and elevated blood ketone values of 103 and $142 \mu$ Eq. per L., respectively.

\section{Liver function studies}

Liver function studies were performed in nine patients with primary influenza virus pneumonia or mixed influenza virus and bacterial pneumonia. With the exception of alterations in the serum glutamic oxaloacetic transaminase levels, no significant abnormalities were noted.

Serum glutamic oxaloacetic transaminase. Twenty-two patients had single or repeated determinations of serum transaminase concentrations. The results of determinations are graphed in Figure 7. As noted, transaminase levels were elevated in the majority of patients studied. In general, the height of serum transaminase concentrations appeared to parallel the severity of the clinical illness. Patients with secondary bacterial pneumonia generally showed the least abnormality. Two patients with primary influenza pneumonia and seven patients with mixed viral and bacterial pneumonia showed elevations of serum transaminase to over 60 units per ml. per minute at some time during the course of their illness.

\section{Studies on blood clotting}

Bloody sputum was a prominent feature of primary influenza virus pneumonia and the concom- 


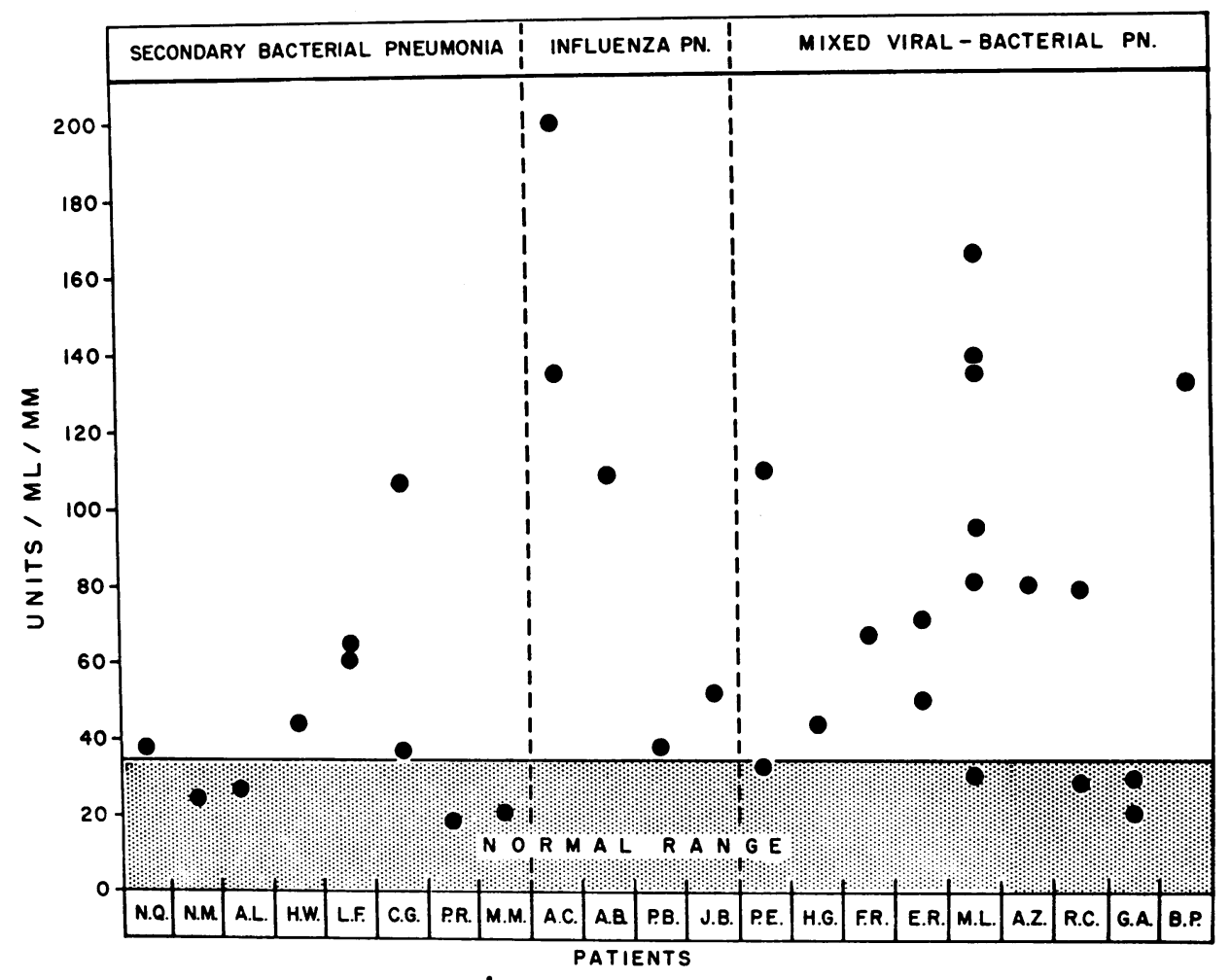

Fig. 7. Serum Glutamic Oxaloacetic Transaminase Levels in Patients with PulmonaRy Complications of Influenza

itant influenza virus-bacterial pneumonia. Studies of bleeding, clotting and prothrombin times, as well as tourniquet and clot retraction tests and quantitative platelet counts were done in five patients with hemoptysis accompanying their illness. All studies were within normal limits.

\section{Other serologic studies}

Serum cold agglutinins were determined on one to six occasions in 18 patients. Seventeen patients showed no detectable cold agglutinins. An initial cold agglutinin titer of $1: 5$ in the serum of one was not present in a second serum. Heterophile antibody concentrations in nine patients were within normal limits.

8. Studies on staphylococci isolated from patients with pulmonary complications

Coagulase positive hemolytic Staphylococcus aureus strains were present in the admission sputum cultures in 12 patients with bacterial or mixed viral and bacterial pneumonias. In six the staphy- lococcus was grown in pure culture from the sputum. In the remaining six patients, other potential pathogens were also recovered in significant numbers.

Bacteriophage typing was performed on 10 of the 12 initial sputum isolates. No single phage type predominated. Three staphylococcal strains were typed in bacteriophage group I, three strains in group III, and two strains had miscellaneous bacteriophage patterns. Two staphylococcus strains were nontypable.

Of these initial isolates, five strains were sensitive to less than one unit of penicillin and seven were penicillin-resistant (1.56 to 50 units per $\mathrm{ml}$.). Seven of the 12 initial isolates were sensitive to tetracycline, 10 to streptomycin, 11 to erythromycin, and 11 to novobiocin. All of the strains which were sensitive to penicillin were also susceptible to all other drugs. Data concerning staphylococcal isolates are summarized in Table $\mathrm{X}$.

As noted in Tables $\mathrm{X}$ and $\mathrm{XI}$, additional strains 
TABLE $\mathrm{X}$

Studies on coagulase positive staphylococcus aureus strains isolated from 12 patients

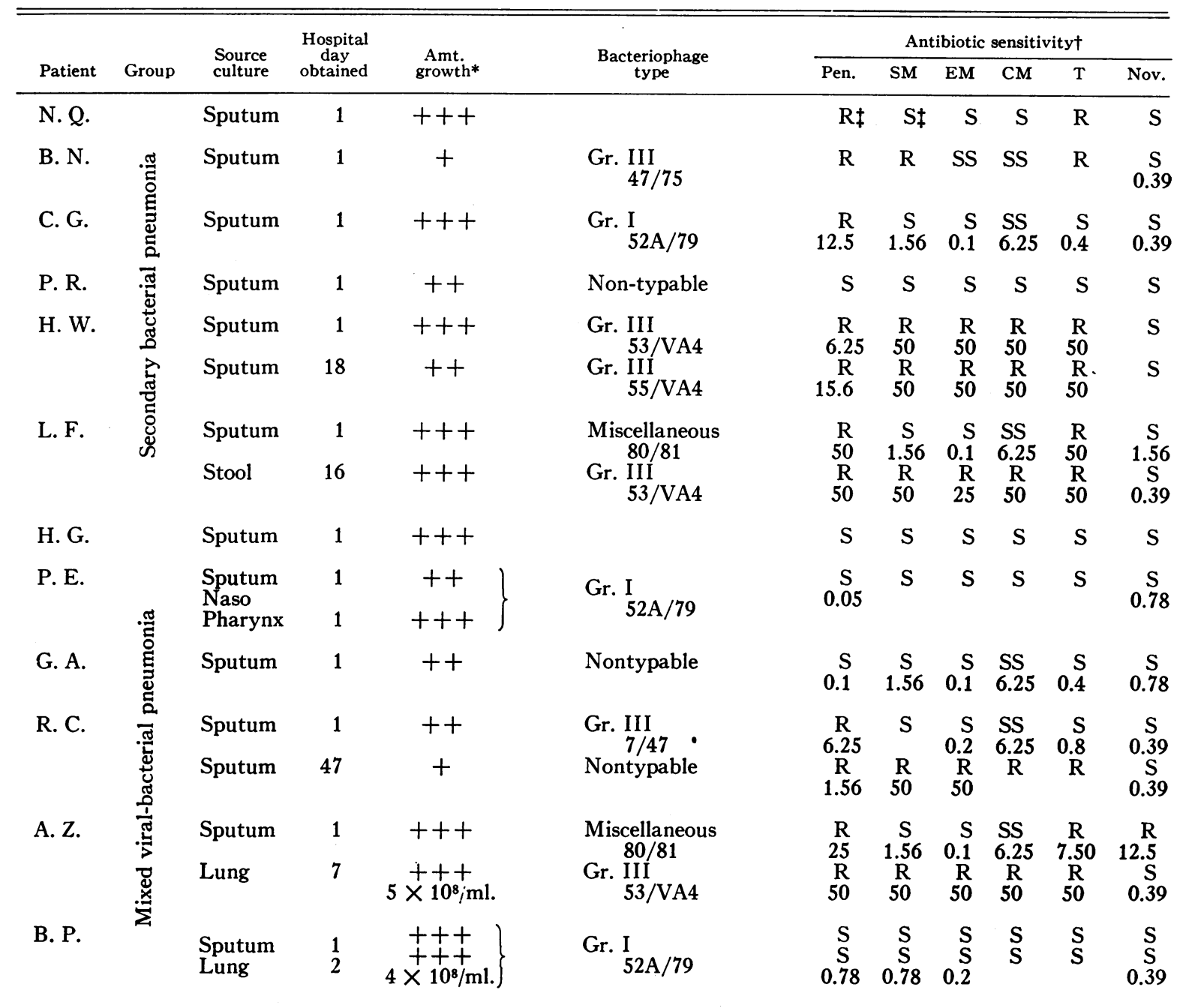
biocin.

$*+$, Occasional colony ++ , appreciable growth +++ , predominating organism and/or pure culture.

† Pen, Penicillin; SM, Streptomycin; EM, Erythromycin; CM, Chloramphenicol; T. Tetracycline; Nov, Novo-

$\ddagger R$, resistant; $S$, sensitive. Where tube dilution sensitivity studies were performed these are recorded in units per $\mathrm{ml}$. for penicillin and $\mu \mathrm{g}$. per $\mathrm{ml}$. for the other antibiotics.

of staphylococci were isolated from five of these patients 16 to 50 days after the initial isolation of staphylococci. In two patients $(\mathrm{H}$. W. and B. P.), strains possessing the same phage pattern and antimicrobial sensitivities were isolated from the sputum and lung, respectively. In the remaining three patients (L. F., R. C. and A. Z.), strains of different phage types were recovered from stool, sputum and lung. In each instance in which a different staphylococcal strain was isolated during hospitalization, it was found to be resistant to the antimicrobial drugs in use (Table XI). This apparent superinfection within the hospital appeared to be of possible importance in the fatal outcome in one patient (A. Z.).

9. Comparison of the virologic findings in patients with different clinical syndromes

Separation of the clinical syndromes described was made on the basis of clinical evidence before virologic information became available. Differences among clinical syndromes with respect to 
TABLE XI

Summary: Antibiotic sensitivities of 17 strains of coagulase positive staphylococic isoalted from patients with influenza and pneumonia

\begin{tabular}{|c|c|c|c|c|c|c|c|c|c|c|c|c|}
\hline & \multicolumn{2}{|c|}{ Penicillin } & \multicolumn{2}{|c|}{ Streptomycin } & \multicolumn{2}{|c|}{ Erythromycin } & \multicolumn{2}{|c|}{ Chloramphenicol } & \multicolumn{2}{|c|}{ Tetracycline } & \multicolumn{2}{|c|}{ Novobiocin } \\
\hline & $\mathrm{S}^{*}$ & $\overline{\mathrm{R}^{*}}$ & $\mathrm{~s}$ & $\mathbf{R}$ & $\mathrm{s}$ & $\overline{\mathrm{R}}$ & $\mathrm{s}$ & $\overline{\mathbf{R}}$ & $\mathrm{s}$ & $\overline{\mathbf{R}}$ & $\mathrm{S}$ & $\mathbf{R}$ \\
\hline \multicolumn{13}{|l|}{ Primary sputum } \\
\hline $\begin{array}{l}\text { isolations } \\
\text { (12 patients) }\end{array}$ & 5 & 7 & 10 & 2 & 11 & 1 & 10 & 2 & 7 & 5 & 11 & 1 \\
\hline \multicolumn{13}{|l|}{ Second isolations } \\
\hline $\begin{array}{l}\text { of staphylococci } \dagger \\
\text { (5 patients) }\end{array}$ & 1 & 4 & 1 & 4 & 1 & 4 & 1 & 4 & 1 & 4 & 5 & 0 \\
\hline
\end{tabular}

* S, sensitive; $\mathrm{R}$, resistant.

$\dagger$ Different phage type in three of five. Source of second isolates: sputum (eighteenth and forty-seventh days of hospitalization), two; lung (second and seventh days of hospitalization), two; stool (sixteenth day of hospitalization), one.

the incidence of virus recovery from throat washings and the concentrations of virus obtained from lungs at autopsy were subsequently noted. These differences are summarized in Table XII.

Throat washings taken from 13 patients with secondary bacterial pneumonia did not yield influenza virus in any patient. In contrast, influenza virus was recovered from throat washings of nine of 12 patients believed to have primary influenza virus pneumonia or mixed viral-bacterial pneumonia. Significant differences were also noted in the concentration of influenza virus in lung tissues obtained from patients dying with primary influenza pneumonia or mixed viral-bacterial in- fections. Three of the four patients who died with the syndrome of primary influenza virus pneumonia had pulmonary concentrations of influenza virus above $10^{4}$ infectious units $\left(\mathrm{EID}_{50}\right)$ per $\mathrm{Gm}$. of tissue. In contrast, virus concentrations of less than $10^{2}$ infectious units per $\mathrm{Gm}$. were obtained in lungs of the three of four patients dying with mixed viral-bacterial pneumonia in whom influenza virus could be recovered.

\section{Evidence of central nervous system involve- ment}

Three patients showed during their illness abnormalities which suggested the possibility of

TABLE XII

Summary: Influenza virus isolations from throat washings and lung specimens

\begin{tabular}{|c|c|c|c|c|c|c|c|c|c|c|c|}
\hline \multicolumn{4}{|c|}{ Secondary bacterial pneumonia } & \multicolumn{4}{|c|}{ Primary influenza virus pneumonia } & \multicolumn{4}{|c|}{ Mixed influenza virus-bacterial pneumonia } \\
\hline Patient & $\begin{array}{l}\text { Day of } \\
\text { illness } \\
\text { specimen } \\
\text { obtained }\end{array}$ & $\begin{array}{l}\text { Speci- } \\
\text { men }\end{array}$ & Result & Patient & $\begin{array}{l}\text { Day of } \\
\text { illness } \\
\text { specimen } \\
\text { obtained }\end{array}$ & $\underset{\text { Speci- }}{\text { men }}$ & $\begin{array}{c}\text { Result } \\
\text { (conc./Gm. } \\
\text { lung) } \dagger\end{array}$ & Patient & $\begin{array}{l}\text { Day of } \\
\text { illness } \\
\text { specimen } \\
\text { obtained }\end{array}$ & $\begin{array}{c}\text { Speci- } \\
\text { men }\end{array}$ & $\begin{array}{c}\text { Result } \\
\text { (conc./Gm } \\
\text { lung) } \dagger\end{array}$ \\
\hline \multirow{14}{*}{$\begin{array}{l}\text { R. S. } \\
\text { B. N. } \\
\text { C. G. } \\
\text { D. P. } \\
\text { M. M. } \\
\text { R. L. } \\
\text { P. R. } \\
\text { N. M. } \\
\text { A. L. } \\
\text { G. M. } \\
\text { H. W. } \\
\text { L. F. } \\
\text { A. M. }\end{array}$} & \multirow{14}{*}{$\begin{array}{r}3 \\
15 \\
12 \\
7 \\
6 \\
7 \\
4 \\
6 \\
1 \\
13 \\
35 \\
9 \\
7\end{array}$} & \multirow{14}{*}{$\begin{array}{l}\text { TW* } \\
\text { TW } \\
\text { TW } \\
\text { TW } \\
\text { TW } \\
\text { TW } \\
\text { TW } \\
\text { TW } \\
\text { TW } \\
\text { TW } \\
\text { TW } \\
\text { TW } \\
\text { TW }\end{array}$} & \multirow{14}{*}{$\begin{array}{l}0 \\
0 \\
0 \\
0 \\
0 \\
0 \\
0 \\
0 \\
0 \\
0 \\
0 \\
0 \\
0\end{array}$} & \multirow{7}{*}{$\begin{array}{l}\text { G. H. } \\
\text { C. P. } \\
\text { A. B. }\end{array}$} & \multirow{2}{*}{5} & \multirow{2}{*}{ Lung } & \multirow{2}{*}{$\underset{10^{5.3}}{++}$} & $H G$ & 7 & TW & 0 \\
\hline & & & & & & & & $\begin{array}{l}\text { H. G. } \\
\text { P.E. }\end{array}$ & 3 & TW & $\begin{array}{l}0 \\
+\end{array}$ \\
\hline & & & & & 3 & Lung & $++t$ & E. R. & 1 & TW & + \\
\hline & & & & & & & $10^{5.7}$ & G. A. & 3 & TW & + \\
\hline & & & & & 3 & TW & + & R. C. & 5 & TW & 0 \\
\hline & & & & & 4 & Lung & $++t$ & & 53 & Lung & 0 \\
\hline & & & & & & & $10^{4}$ & M. L. & 3 & TW & + \\
\hline & & & & P. B. & 2 & TW & 0 & & ? $1-4$ & TW & + \\
\hline & & & & J. B. & 3 & TW & + & F. R. & ? 6-10 & Lung & + \\
\hline & & & & & 11 & Lung & 0 & & & & $10^{2}$ \\
\hline & & & & & 3 & TW & + & & 4 & TIV & + \\
\hline & & & & A. C. & 4 & Lung & + & A. $Z$. & 10 & Lung & + \\
\hline & & & & & & & $10^{2}$ & & 4 & $T W$ & $\begin{array}{l}10^{2} \\
+\end{array}$ \\
\hline & & & & & & & & B. P. & 4 & Lung & $\begin{array}{l}+ \\
10^{2.7}\end{array}$ \\
\hline
\end{tabular}

* TW, throat washing.

† Concentrations of virus recorded in 50 per cent egg infectious doses $\left(E I D_{60}\right)$. 
central nervous system involvement. One patient (J. B.), a 75 year old woman with primary influenza virus pneumonia, entered the hospital in semicoma and remained comatose throughout her 10 day hospital course. Focal neurologic signs were not present. Cerebrospinal pressure, cell count, protein, sugar and chloride were normal on two occasions, and influenza virus was not recovered from cerebrospinal fluid.

A second patient (A. C.) with primary influenza virus pneumonia had a series of convulsions followed by coma 24 hours after admission and expired eight hours later. At autopsy no pathologic abnormalities were detected in the brain.

The third patient (P. E.) with combined bacterial and viral pneumonia initially responded well to oxygen and antimicrobial therapy. On his third hospital day he became lethargic. Twentyfour hours later he was noted to have a partial left III cranial nerve paresis and a mild right hemiplegia. Cerebrospinal fluid was slightly xanthochromic. Cerebrospinal fluid protein was 54 mg. per cent and the cell count was normal. $\mathrm{X}$-rays of the skull were normal and parietal burr holes did not reveal evidence of a subdural hematoma. Electroencephalograms were diffusely abnormal and were felt to be compatible with encephalitis. No virus could be recovered from the cerebrospinal fluid. During the next three weeks the patient remained lethargic, confused, and disoriented. His mentation changes and neurologic signs gradually improved, although at the time of discharge 40 days after admission his electroencephalogram remained markedly abnormal.

Whether the changes noted in these patients were related to severe hypoxia and profound illness or were a direct result of influenza virus infection was not satisfactorily answered by the present study.

\section{The course and therapy of infuenza with pul- monary complications}

\section{Influenza with secondary bacterial pneu- monia}

Patients with secondary bacterial pneumonia following influenza responded to treatment in a manner which did not differ from that observed in bacterial pneumonia uncomplicated by influenza.
The eight patients with pneumococcal pneumonia responded promptly to antimicrobial therapy which consisted of penicillin alone in five patients, penicillin in combination with erythromycin and streptomycin in two, and erythromycin and tetracycline in one patient who had a history of penicillin allergy. Temperatures returned to normal in two to eight days and physical findings of pneumonia cleared in four to 16 days.

The five patients with staphylococcal pneumonia following influenza also responded satisfactorily to antimicrobial therapy. Four of these patients had infections produced by strains which were resistant to penicillin but sensitive to erythromycin and chloramphenicol. These four patients received antimicrobial regimens which included erythromycin. The fifth patient, with pneumonia caused by a staphylococcal strain resistant to high concentrations of streptomycin, chloramphenicol and erythromycin, appeared to respond to therapy which utilized all three of these agents. In this group, temperature response was slower, taking from four to 13 days for complete return to the afebrile state. Roentgenograms cleared more slowly. One patient developed roentgenographic evidence of pulmonary cavitation with subsequent slow resolution. The single patient with pneumonia apparently due to Hemophilus influenzae responded promptly to therapy with chloramphenicol and erythromycin.

One patient (B. N.) developed her pneumonia while in the hospital. Sputum cultures consistently yielded Aerobacter aerogenes, Candida albicans and small numbers of hemolytic Staphylococcus aureus. Despite the administration of penicillin, streptomycin, tetracycline, erythromycin and chloramphenicol in varying combinations, she showed no significant improvement. On the thirty-seventh day of her illness the patient died suddenly with symptoms suggestive of a massive pulmonary embolus. No autopsy was obtained on this patient.

\section{Primary influenza virus pneumonia}

Treatment of the syndrome of primary influenza pneumonia was unsatisfactory, and only one of six patients in this group survived. Major therapeutic problems were the high, unremitting fever, progressive respiratory disease with increasing hypoxia and the increasing respiratory and metabolic acidosis. 
TABLE XIII

\begin{tabular}{|c|c|c|c|}
\hline \multirow[b]{2}{*}{ Patient } & \multicolumn{3}{|c|}{$\begin{array}{c}\text { Arterial oxyhemoglobin saturation } \\
(\text { per cent })^{*}\end{array}$} \\
\hline & $\begin{array}{l}\text { Without } \\
\mathrm{O}_{2}\end{array}$ & $\begin{array}{c}\text { Positive } \\
\text { pressure } \\
\text { mask- } \\
100 \% \mathrm{O}_{2}\end{array}$ & $\begin{array}{l}\text { IPPB } \\
100 \% \mathrm{O}_{2}\end{array}$ \\
\hline J. B. & $\begin{array}{l}46.2 \\
73.5 \\
69.9\end{array}$ & 91.0 & $\begin{array}{l}96.5 \\
91.5 \\
94.7 \dagger\end{array}$ \\
\hline F. R. & 50.5 & & 91.5 \\
\hline A. $Z$. & 71.1 & 82.6 & 93.9 \\
\hline
\end{tabular}

* All specimens were taken serially from the brachial artery; 15 to 20 minutes was allowed for stabilization under each test condition before samples were obtained.

$\dagger$ Forty per cent $\mathrm{O}_{2}$ administered.

Despite the lack of evidence of bacterial infection, each patient received intensive antimicrobial therapy, the details of which are outlined in the individual case reports. In no instance was there any apparent improvement following administration of antibacterial agents.

The severe hypoxia and marked cyanosis were not corrected by the use of an oxygen tent or routine oxygen face mask. Arterial blood oxygen saturation studies performed on three patients indicated that oxygen administered via the Bennett Intermittent Positive Pressure Breathing (IPPB) 4 Apparatus resulted in maximal improvement in oxyhemoglobin saturation. As noted in Table XIII, significant increase in arterial oxygen saturation followed the use of a positive pressure mask, but in each case further improvement in oxygen saturation was achieved by use of the IPPB mask.

Unfortunately, the IPPB mask was not tolerated by most patients for prolonged periods of time. The cycling apparatus proved fatiguing to the patient, and claustrophobia and agitation were commonly intensified by the mask. Also, the introduction of air under pressure was frequently irritating and appeared to dry the pharynx and tracheobronchial passages. This often resulted in thick tenacious secretions which were difficult to remove despite maintenance of high humidity in

4 The IPPB mask used in these studies was obtained from V. Ray Bennett and Assoc., Inc., Los Angeles, Calif. the mask by alternating aerosols of bronchodilators, Alevaire ${ }^{\circledR}$ and normal saline. The one patient who survived was the only patient able to tolerate intermittent positive pressure breathing for long periods of time.

Five of the six patients, including the patient who survived, received adrenal steroids in doses which varied from the equivalent of $400 \mathrm{mg}$. to $1,000 \mathrm{mg}$. of cortisone acetate daily. Steroids used were hydrocortisone, which was administered intravenously, or prednisone, which was given intramuscularly or orally. In the majority of patients the administration of steroids appeared to reduce the fever. In certain instances, discussed in more detail in the case reports, the administration of intravenous hydrocortisone appeared to result in a transient improvement in the pulmonary signs and respiratory distress. Nevertheless, steroids did not appear to alter significantly the overall course of the illness.

\section{Coincident influenza virus and bacterial pneumonia}

Five of the nine patients with combined viral and bacterial pneumonia recovered despite the critical nature of their illness upon admission. Therapy was similar to that utilized in primary influenza virus pneumonia except for the choice of antibiotics. In each instance, antibacterial therapy with penicillin, streptomycin and either erythromycin or chloramphenicol was administered until a specific bacteriologic agent was isolated and its in vitro sensitivity to antibiotics determined. Thereupon the antibiotic regimen was altered when necessary to include the most appropriate antimicrobials. Oxygen therapy was administered in the same manner as in primary influenza virus pneumonia and was fraught with the same difficulties.

Seven of the nine patients also received steroid hormones in dosage equivalent to 400 to $1,000 \mathrm{mg}$. cortisone acetate daily. Temperatures fell towards normal concurrently with steroid therapy in four of the seven. Dramatic temporary improvement with subsequent relapse was noted following steroid treatment in one patient (R. C.). In the remaining patients there were no striking effects on the clinical course.

Four patients with evidence of combined viral 
and bacterial pneumonia died during the course of their illness. One patient (F. R.) with pneumococcal and viral pneumonia died on the sixth day of his illness with a progressive diffuse pulmonary disease in every way similar to that seen in primary influenza virus pneumonia. Lung specimens obtained post mortem were sterile on bacteriologic culture, and influenza virus was recovered in a concentration of $10^{2}$ infectious units $\left(\mathrm{EID}_{\mathrm{s0}}\right)$ per $\mathrm{Gm}$.

Two patients (A. Z. and B. P.) died of overwhelming staphylococcal and influenza virus pneumonia. One patient (R. C.) died 53 days after the onset of her initial influenza symptoms with an acute myocarditis and pulmonary arteritis of unknown etiology. Patients A. Z., B. P. and R. C. are described in detail in the case report section.

\section{Treatment of the hypercapnea and respiratory} acidosis observed in patients with diffuse pulmonary involvement

Seven of the 15 patients with primary viral or combined viral and bacterial pneumonia developed progressive respiratory acidosis with increasing partial pressures of carbon dioxide and falling arterial blood $\mathrm{pH}$. In five patients serum bicarbonate levels rose progressively as carbon dioxide tension rose, resulting in a partially compensated acidosis.

Because of the severe carbon dioxide retention, acetazoleamide (Diamox ${ }^{\circledR}$ ), $250 \mathrm{mg}$., was administered every six hours to four of these patients for periods of several days. The results of this therapy are presented in Table XIV.

Three patients had a diuresis and serum carbon dioxide combining power returned to normal. No significant fall in blood $\mathrm{pH}$ occurred during acetazoleamide therapy, and all three patients showed definite clinical improvement with reduction in pulmonary signs and subjective respiratory distress. In the remaining patient (A. Z.) a return of blood carbon dioxide and $\mathrm{pH}$ to normal was noted, but no clinical improvement was observed.

IV. Pathologic findings at postmortem examination

\section{Primary influenza virus pneumonia}

Complete postmortem examinations were performed on four patients who died with the syn-

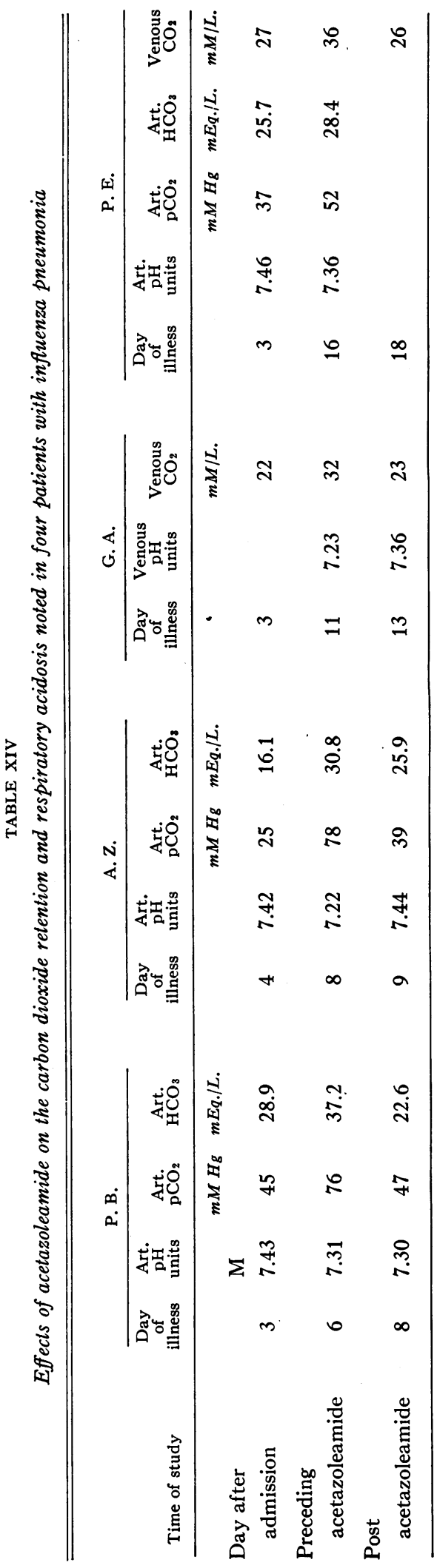




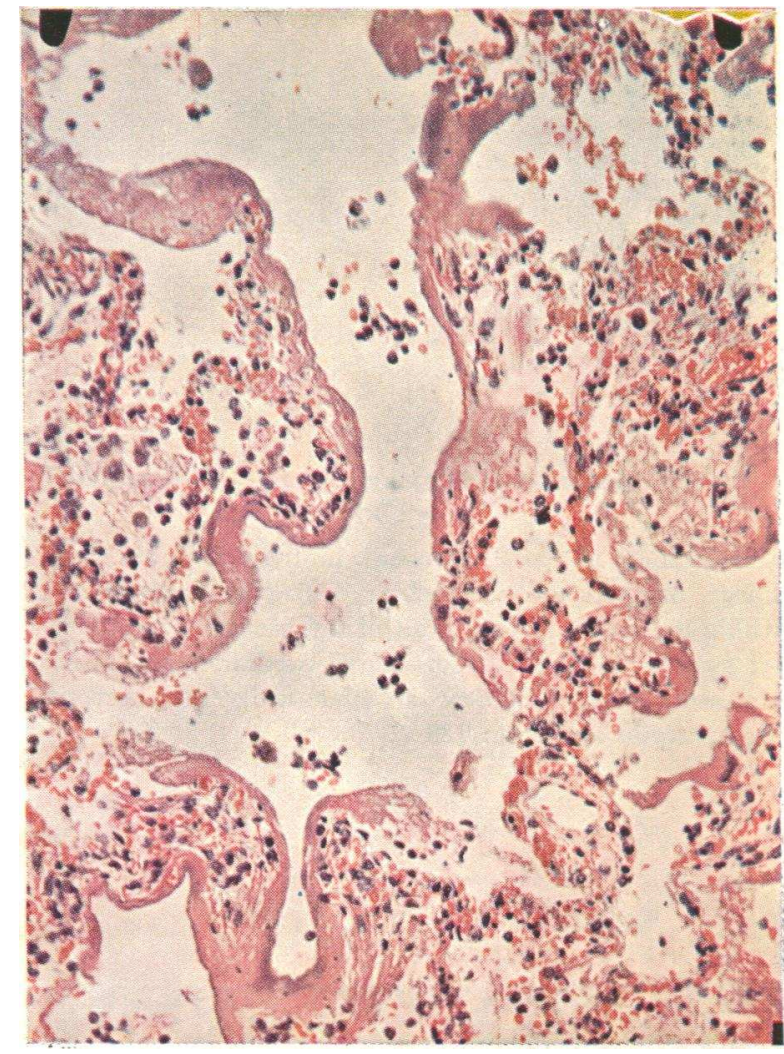

Fig. 9. Primary Influenza Virus Pneumonia, CASE G. H.

Ulceration of a small bronchus in the right lower lobe. Note that adjacent alveoli are filled with erythrocytes admixed with fibrin. Neutrophilic leukocytes are present, but in small numbers. Hematoxylin and eosin $90 \times$.
Fig. 8. Primary Influenza Virus Pneumonia, CAse G. H.

Hyaline acellular membrane lining alveolar ducts and alveoli of the right upper lobe. Note the relative paucity of inflammatory cells or erythrocytes in the alveoli. Hematoxylin and eosin $180 \times$.

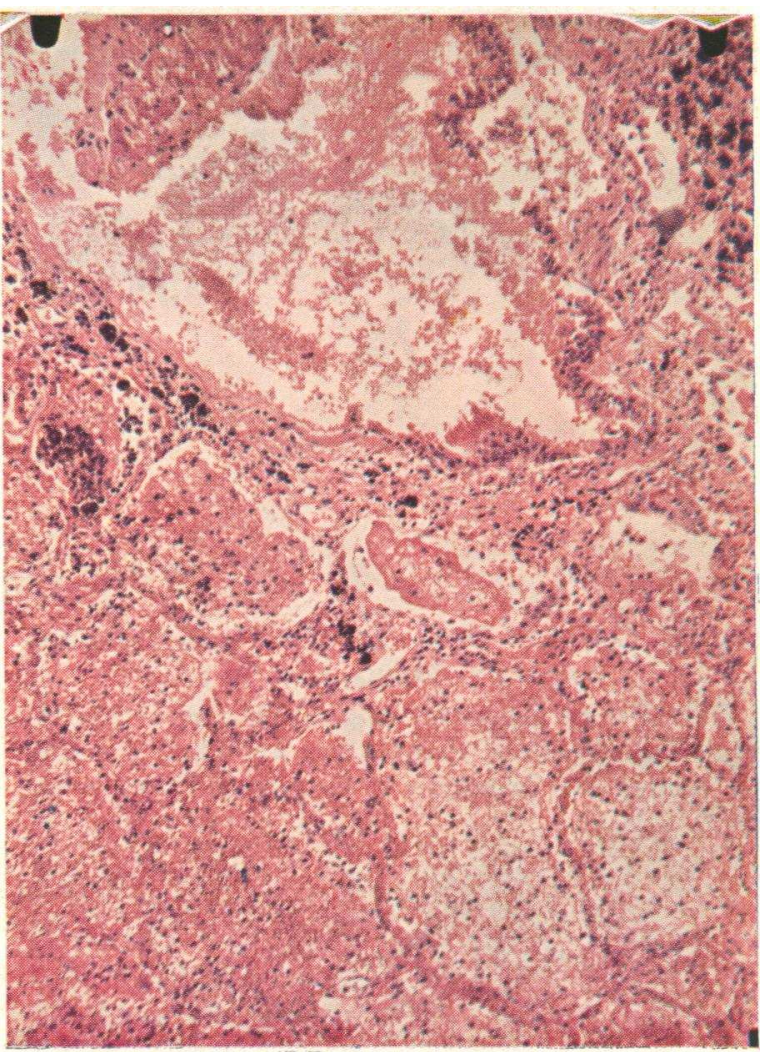




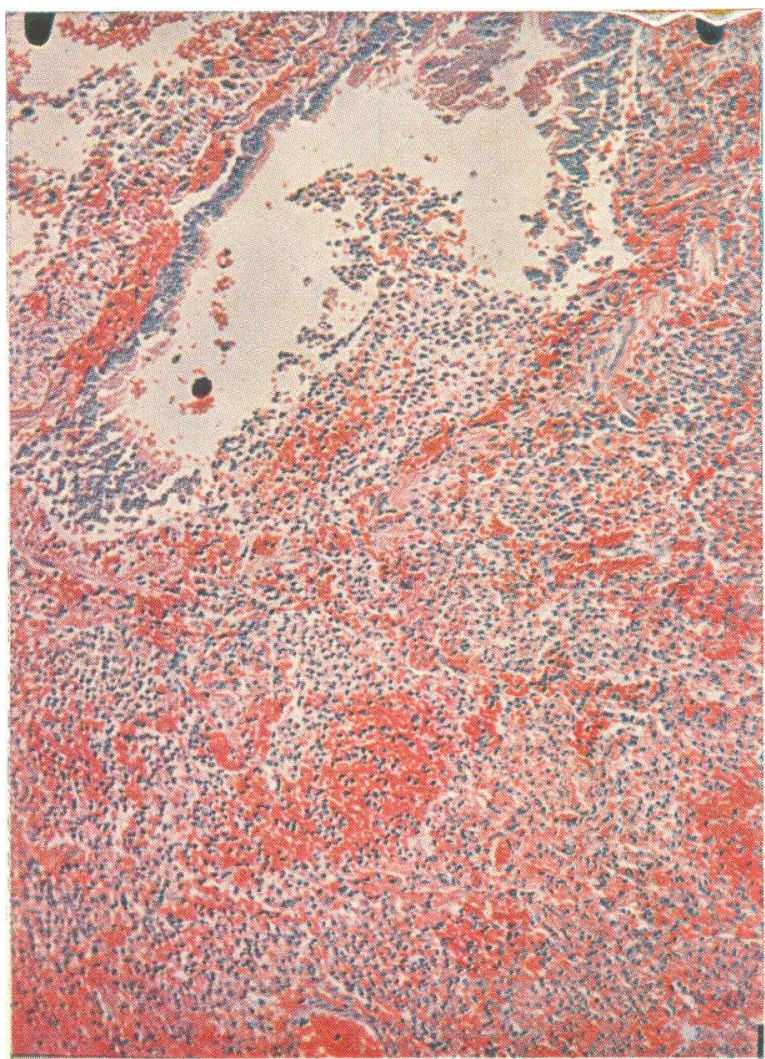

Fig. 11. Combined Influenza Virus and Staphylococcal Pneumonia, Case A. Z.

Wall of small abscess showing central zone of necrosis containing colonies of staphylococci and adjacent masses of neutrophilic leukocytes. Hematoxylin and eosin $240 \times$.
Fig. 10. Primary Influenza Virus Pneumonia, CASE C. P.

Ulceration of small bronchus in the left lower lobe. Large numbers of neutrophilic leukocytes are present within the lumen and the wall of the bronchus and alveolar spaces. Note the hyperemia of capillaries and alveolar hemorrhage. A few alveolar walls are necrotic. Hematoxylin and eosin $120 \times$.

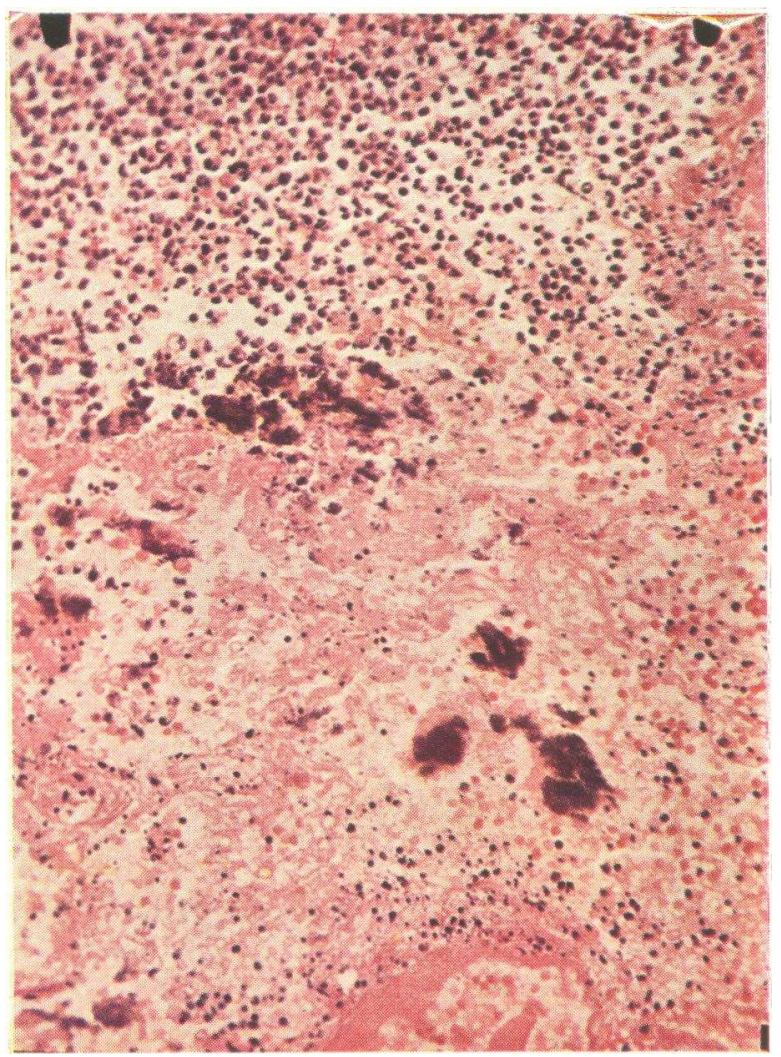


drome believed to represent influenza virus pneumonia without bacterial involvement. Each of these cases showed distinctive gross and microscopic alterations. High titers of influenza virus were demonstrated in the lungs of three, and pathogenic bacteria could not be demonstrated in culture or in numerous histological preparations of the lungs in these patients (G. H., C. P. and A. C.). The fourth case (J. B.) aspirated preterminally, and a small number of fungi and bacteria were demonstrated about aspirated material within bronchi but did not appear of importance in the causation of the diffuse parenchymal changes. In this case, influenza virus was not recovered from the lung but was isolated from the throat washings during life.

The lungs in each of the four cases presented remarkably similar alterations. The trachea and bronchi often contained bloody fluid, and the mucosa was strikingly hyperemic. The parenchyma was dark red, markedly congested, edematous and heavy. The total weight of both lungs varied from 1,600 to $4,000 \mathrm{Gm}$. Crepitus was often greatly diminished or absent, especially in the posterior and inferior portions, and these areas were dark purple-red in contrast to the somewhat lighter color of the upper lobes. On section, large amounts of blood-tinged fluid flowed from the dark red surfaces, and irregular hemorrhagic areas, ranging from a few millimeters to $6 \mathrm{~cm}$. across, were frequently encountered. The pulmonary arteries and veins in these areas were devoid of thrombi.

Widespread and striking microscopic alterations were found in varying degrees in all four cases (Figures 8-10). Tracheitis, bronchitis and bronchiolitis with loss of normal ciliated epithelial cells were prominent and were frequently associated with evidence of epithelial regeneration. Submucosal hyperemia, focal hemorrhage, hemorrhage, edema and a slight cellular infiltrate were present in such areas. The alveolar spaces contained varying numbers of neutrophils and mononuclear cells admixed with fibrin and edema fluid (Figures 8-10). The alveolar capillaries were markedly hyperemic and intra-alveolar hemorrhage was common, particularly in the lower lobes (Figure 9). Focal necrosis of the alveolar septa was found in only one case. In general, all changes described were most marked in the lower lobes, as demonstrated in Figures 8 and 9.

In each of the cases, striking acellular, hyaline membranes lined many of the alveolar ducts and alveoli. Such hyaline membranes were frequently prominent in areas that showed minimal cellular exudation.

Examination of the heart revealed chronic cardiac disease in each of the four. Two patients had severe rheumatic valvular damage with severe mitral valve deformities; one patient showed extensive coronary atherosclerosis. Cardiac changes compatible with longstanding hypertension were noted in the remaining patient.

In no instance was there gross or microscopic evidence of myocarditis. Microscopic examination of the brain failed to show evidence of encephalitis in the three cases in which examination was permitted.

\section{Combined influenza virus and bacterial pneu- monia}

Postmortem studies were also performed on four patients believed to have concomitant influenza virus and bacterial pneumonia. Two patients who died on the fifth and tenth days of illness (B. P. and A. Z.) showed gross and microscopic changes generally similar to those described in the primary influenza virus pneumonia group. In addition, both patients had a diffuse, necrotizing pneumonia. Microabscesses in which myriads of gram-positive cocci could be easily demonstrated were found throughout the lungs (Figure 11). Cultures yielded hemolytic Staphylococcus aureus. Influenza virus was also recovered from the lungs of both cases. Examination of the heart in both cases failed to show abnormalities. The one brain examined showed no gross or microscopic changes.

In the remaining two patients (R. C. and G. A.), death occurred two months after the onset of influenza symptoms. Influenza virus was not recovered from these lungs post mortem, although the virus had been previously obtained from throat washings.

One patient (R. C.) died 53 days after the onset of influenza. At autopsy, chronic rheumatic heart disease with mitral stenosis was found. In addition, a widespread, acute, necrotizing myocarditis 
and subacute pulmonary arteriolitis were present. The lungs failed to show hyaline membrane formation, bronchiolitis or other changes that could be clearly attributed to the initial viral infection. The etiology of the arteriolitis and myocarditis in this patient was not determined. The striking polymorphonuclear infiltration of the myocardium appeared of recent origin.

The remaining patient (G. A., Autopsy No. 17365 ) with a pneumonia believed to be due to both viral and bacterial infection responded well to therapy and was discharged after complete recovery. He re-entered the hospital six weeks later with a fresh myocardial infarction and subsequently expired. Autopsy studies failed to reveal evidence of residual pulmonary abnormalities that could be attributed to the previous influenza infection. The brain appeared normal. The detailed postmortem findings are included in the individual case reports.

\section{CASE REPORTS}

\section{Influenza complicated by bacterial pneumonia}

The four patients discussed below characterize the spectrum of illness as observed in 15 patients who developed bacterial pneumonia following influenza infection.

1. N. Q., NYH 778883. A 21 year old white man was admitted on Sept. 30, 1957, with fever, chest pain and bloody sputum. Five days prior to admission the patient had noted the onset of a moderately sore throat, chilly sensations, anorexia, photophobia, dry cough and eye ball soreness. On bedrest there was progressive improvement over the next three days. The evening before admission the patient became precipitously worse. He developed pleuritic right anterolateral chest pain, and his cough became productive of bloody sputum.

Physical examination on admission revealed a temperature of $40.5^{\circ} \mathrm{C}$., heart rate of 100 beats per minute, respirations of 30 per minute and blood pressure of 150/ $60 \mathrm{~mm}$. Hg. The patient was lethargic and acutely ill. There was splinting of the right lower thorax on respiration. A right pleural friction rub was present, and dullness to percussion, bronchial breath sounds, egophony and fine inspiratory rales were noted over the right base posteriorly. The remainder of the physical examination was not remarkable.

Initial laboratory studies showed a white blood cell count of 12,200 per cu. mm. with 71 per cent mature polymorphonuclear cells and 10 per cent immature forms. The erythrocyte sedimentation rate was $46 \mathrm{~mm}$. per hour. Sputum smears demonstrated many polymorphonuclear cells and masses of gram-positive cocci. Sputum cul- tures contained an almost pure growth of hemolytic Staphylococcus aureus. This microorganism was resistant to penicillin but sensitive to erythromycin, chloramphenicol, streptomycin and novobiocin. The admission chest roentgenogram, shown in Figure 12, demonstrated a localized right lower lobe infiltrate.

Therapy was initiated with aqueous penicillin, 2.4 million units per day; dihydrostreptomycin, $2 \mathrm{Gm}$. per day; and erythromycin, $2 \mathrm{Gm}$. per day. The course of the patient's illness is shown in Figure 13. During the first five days the temperature ranged to above $39^{\circ} \mathrm{C}$. and the patient remained extremely ill. A right pleural effusion developed which was sterile upon culture. During the ensuing 18 days the temperature returned gradually to normal, and the pleural effusion slowly resolved. A chest roentgenogram taken on the tenth hospital day showed cavity formation within the area of pneumonia (Figure 14). Complete resolution occurred on continued therapy, and the patient was discharged asymptomatic after 32 days of hospitalization. A serum obtained late in his illness (22 days) showed a complement fixing titer of 1:512 against the Japan 305 strain of influenza virus.

Comment. This patient had rather typical staphylococcal pneumonia following influenza caused by a strain sensitive to most antibiotics. There was a definite period of improvement after influenza, followed by new symptoms consisting of pleural pain, marked exacerbation of cough, and

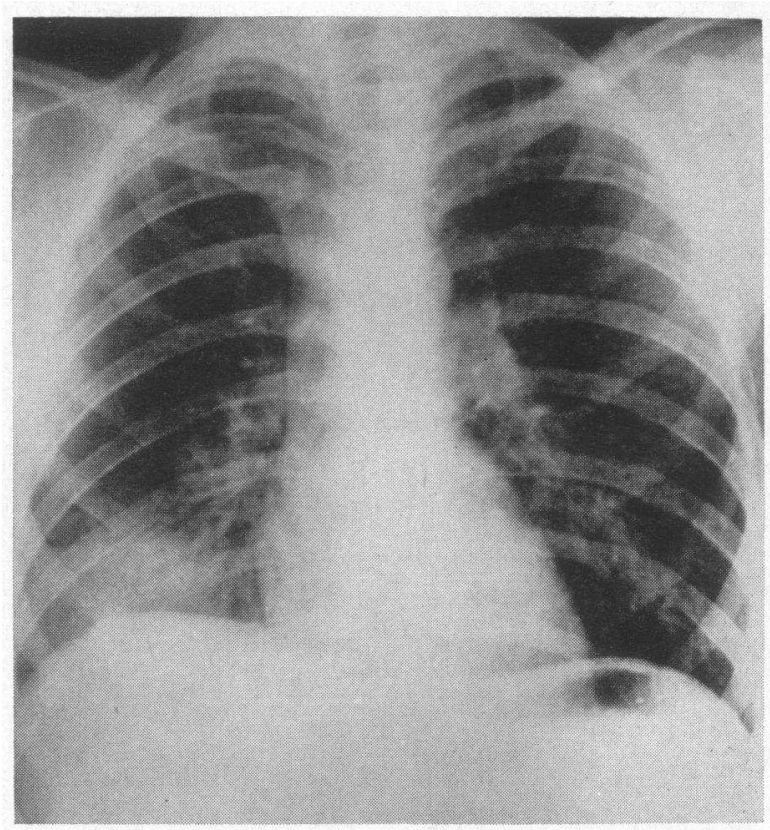

Fig. 12. Admission Chest Roentgenogram on Patient N. Q., a 21 Year Old Man with Influenza Complicated by Staphylococcal Pneumonia of the RIGHT LOWER LOBE 


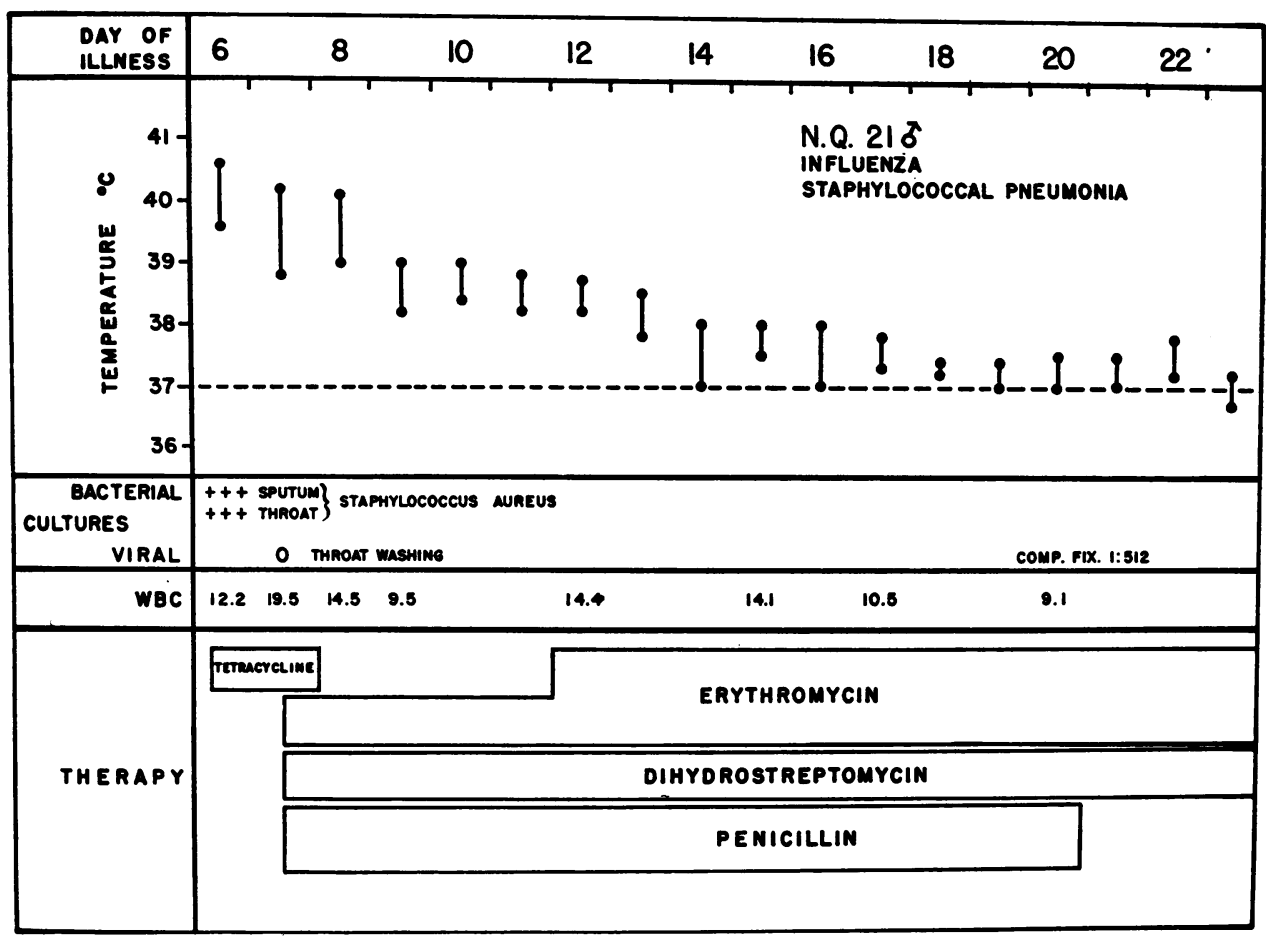

Fig. 13. Course of Illness in Patient N. $Q$.

bloody sputum which heralded the onset of the staphylococcal infection.

2. C. G., NYH 780147. A 59 year old white man was admitted on Oct. 4, 1957, with fever, chest pain and a productive cough. The patient was well until 11 days prior to admission when he developed fever, headache, sore throat, diffuse myalgias, diarrhea, vomiting and cough which was productive of small amounts of grayish sputum. On bedrest he improved quite markedly so that two days later he was able to return to work. The next day he had a shaking chill and noted the onset of left chest pain, and his cough increased. He was treated with penicillin and tetracycline, but his symptoms continued and he was admitted to the hospital.

Physical examination revealed a well-developed, wellnourished man who appeared in no acute distress. Admission temperature was $38.5^{\circ} \mathrm{C}$., pulse 76 beats per minute, respirations 24 per minute, and blood pressure $130 / 70 \mathrm{~mm}$. Hg. Examination of the chest revealed dullness to percussion posteriorly over the medial part of both lower lung fields. Breath sounds were diminished, and sticky, inspiratory rales were heard over the areas of dullness. The remainder of the physical examination was within normal limits.

The initial white blood cell count was 13,600 leukocytes per cu. mm. with 69 per cent mature polymorphonuclear cells and 17 per cent band forms; the erythrocyte sedimentation rate was $22 \mathrm{~mm}$. per hour. Examination of sputum smears revealed many polymorphonu- clear cells and gram-positive cocci. Sputum cultures showed a heavy growth of hemolytic Staphylococcus aureus (phage type 52A/79) and Hemophilus influenzae. The staphylococcus isolated was resistant to 6.25 units of penicillin and sensitive to streptomycin, erythromycin, tetracycline, chloramphenicol and novobiocin. Chest roentgenogram showed a bilateral lower lobe pneumonia. Influenza virus was not recovered from a throat washing.

The patient was placed on a daily dosage of $2 \mathrm{Gm}$. each of dihydrostreptomycin, erythromycin and chloramphenicol. He became afebrile by the fourth hospital day and remained so during the remainder of hospitalization. The physical signs of pulmonary involvement cleared slowly. One month after admission, physical and roentgenologic examination were both within normal limits. Serum obtained on Days 14 and 24 showed complement fixing antibody titers of $1: 512$ and $1: 1024$ respectively against the Japan 305 strain of influenza virus.

Comment. This patient had a bacterial pneumonia following typical influenza. Both hemolytic Staphylococcus aureus and Hemophilus influenzae were cultured from the sputum. A distinct period of improvement after influenza was followed by symptoms suggesting bacterial pulmonary infection. Complete recovery followed prolonged antimicrobial therapy.

3. D. P., NYH 495539. A 15 year old school girl was admitted on Oct. 11, 1957, with fever. headache and a 


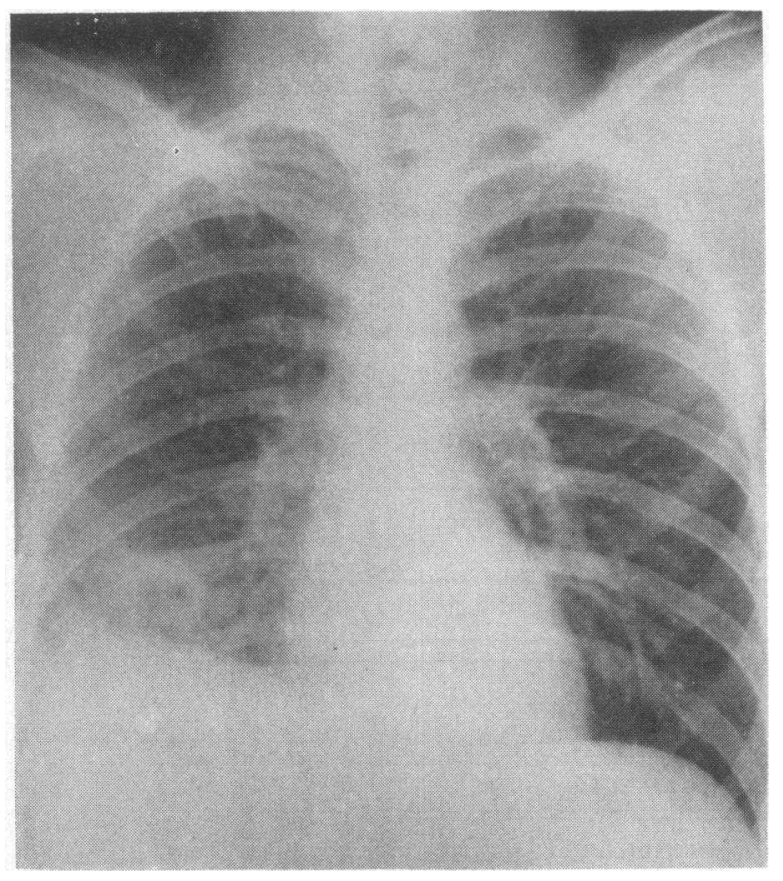

Fig. 14. Chest Roentgenogram on Patient N. Q. on Day 10 of Hospitalization Showing a Multiloculated Cavity in the Area of Pneumonia

productive cough. Five days prior to admission the patient developed a frontal headache which was rapidly followed by anorexia, chilliness, fever and diffuse myalgia. A cough developed which was productive of small amounts of yellow, thick sputum. Three days before admission she had returned to school, but profound malaise, anorexia and productive cough persisted.

At admission, physical examination revealed a temperature of $39^{\circ} \mathrm{C}$., pulse rate 100 beats per minute, respirations 28 per minute, and blood pressure of $108 / 80 \mathrm{~mm}$. Hg. Splinting of the left hemithorax and tenderness of the left lower chest to palpation were noted. Signs of consolidation were evident over the left lower lung field posteriorly, and a pleural friction rub was present. Physical examination was otherwise within normal limits.

The initial white blood count was 10,200 per cu. $\mathrm{mm}$. with 60 per cent polymorphonuclear leukocytes, 17 per cent immature granulocytes, and the erythrocyte sedimentation rate was $34 \mathrm{~mm}$. per hour. Sputum smears showed many gram-positive diplococci, and cultures of the nose, throat and sputum disclosed large numbers of pneumococci, type VIII. Mouse inoculation of sputum from the patient also yielded the same organism. The admission chest roentgenogram revealed a left lower lobe infiltrate.

Therapy was instituted with 300,000 units of procaine penicillin administered every 12 hours. The patient became afebrile 18 hours after admission and remained so during the remainder of her hospitalization. Chest roentgenograms showed complete clearing of the pneumonic infiltrate by the eighth hospital day. A 16-fold rise in complement fixing antibody to influenza A virus (Japan 305 strain) was demonstrated with paired sera obtained on the sixth and sixteenth day of the patient's illness.

Comment. This patient developed pneumococcal lobar pneumonia following typical influenza. In this instance the bacterial complication blended with the initial viral infection. At no time during her illness was there a definite change in symptomatology which dated the onset of her bacterial infection. The response on appropriate antibiotic therapy was satisfactory.

4. R. L., NYH 506121. A 22 year old white man with severe muscular dystrophy was admitted on Oct. 17, 1957, because of fever, dyspnea and chest pain. Six days prior to admission he developed an illness characterized by diffuse myalgia, fever, cough and bifrontal headache. Over the next three days he improved but then noted a sudden exacerbation of symptoms with increased cough productive of blood-streaked sputum, chest pain and dyspnea. These symptoms became progressively worse and necessitated hospitalization.

On admission, physical examination revealed a young man with extensive muscular dystrophy who was in moderate respiratory distress. There was minimal cyanosis of the lips and nailbeds. The admission temperature was $39.6^{\circ} \mathrm{C}$., heart rate 110 per minute, respirations 22 per minute, and blood pressure $120 / 80 \mathrm{~mm}$. Hg. Bilateral inspiratory sticky rales were heard over the lower lobes posteriorly, and signs of consolidation were evident over the right upper lobe. The remainder of the physical examination was unremarkable.

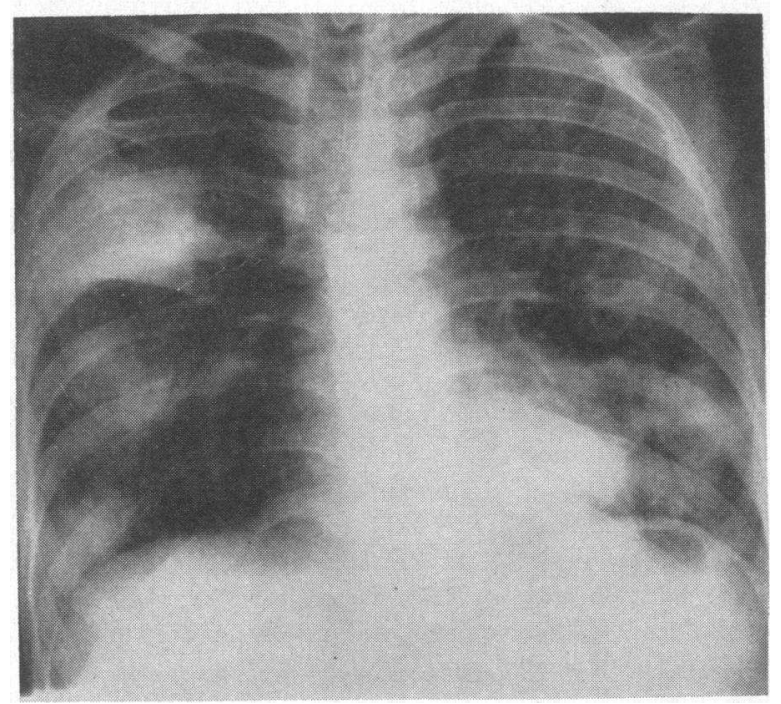

Fig. 15. Admission Chest Roentgenogram on Patient R. L., a 32 Year Old Man with Influenza Complicated by Pneumococcal Pneumonia of Right UPPER, Right Lower and Left Lower Lobes 


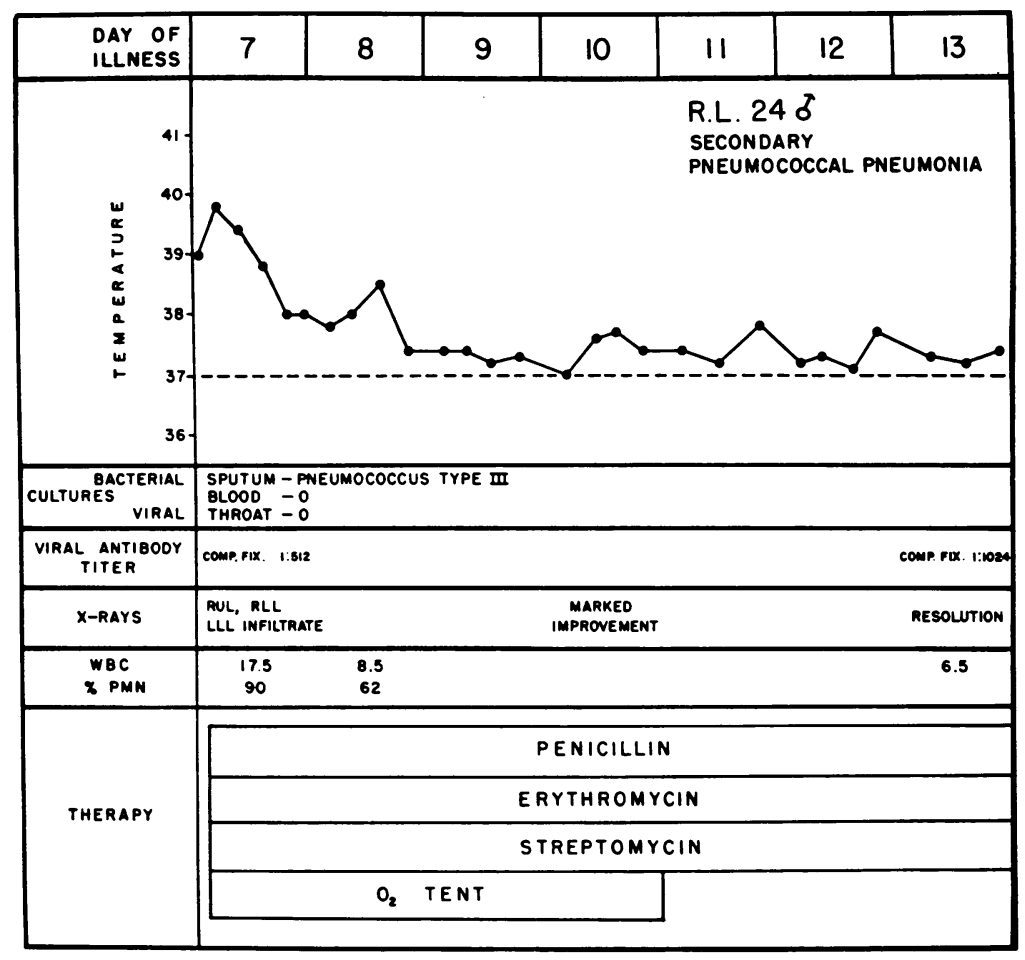

Fig. 16. Course of Illness in Patient R. L.

The admission white blood cell count was 17,500 cells per $\mathrm{cu}$. mm. with 90 per cent polymorphonuclear leukocytes. The carbon dioxide combining power was $32 \mathrm{mM}$ per L. A chest roentgenogram revealed infiltrates of the right upper lobe, right lower lobe and left lower lobe (Figure 15). No sputum could be raised by the patient upon admission. Large numbers of pneumococci, type III, were demonstrated in admission throat cultures. Blood cultures were sterile.

Influenza virus was not isolated from initial throat washings obtained on Day 7 of illness, but complement fixing antibody titers of 1:512 and 1:1024 were demonstrated with serums taken on the seventh and eighteenth days of illness.

The patient's course is pictured in Figure 16. Therapy consisted of oxygen by tent; streptomycin, $2 \mathrm{Gm}$. per day: erythromycin, $2 \mathrm{Gm}$. per day; and penicillin, 2.4 million units per day. The patient became afebrile in 48 hours and recovery thereafter was uneventful.

Comment. This patient with muscular dystrophy had typical influenza followed three days later by pneumococcal pneumonia involving three lobes. Prompt and uneventful recovery followed institution of antimicrobial therapy.

\section{Primary influenza virus pneumonia}

Six patients in the present series had influenza virus infection without demonstrable bacterial in- fection. Because of the importance of documenting this syndrome, the essential data relative to all six patients are reported here.

1. G. H., NYH 746483. A 49 year old man with long standing rheumatic mitral stenosis and insufficiency was admitted on Oct. 5, 1957, with a 20 hour history of fever and progressive respiratory difficulty. The day prior to admission the patient had developed generalized myalgia, headache, fever and a nonproductive cough. During the next 18 hours his cough became progressively worse and productive of bloody sputum. Dyspnea increased relentlessly and precipitated his admission.

On admission the patient appeared cyanotic, markedly dyspneic and critically ill. The admission temperature was $40^{\circ} \mathrm{C}$., the pulse was irregular at 90 beats per minute, respirations were 40 per minute, and blood pressure 125/ $80 \mathrm{~mm} . \mathrm{Hg}$.

The neck and arm veins were not distended. Examination of the chest revealed no evidence of local consolidation. Coarse inspiratory rales and occasional rhonchi at both lung bases posteriorly were the only pulmonary findings, despite the severe respiratory distress. The heart was markedly enlarged and had a mitral configuration. The rhythm was that of auricular fibrillation. A harsh, blowing systolic murmur was heard at the apical area, but because of the patient's stertorous breathing no other murmurs could be distinguished. The liver was not enlarged and peripheral edema was not detected.

Laboratory studies revealed a hemoglobin concentra- 
tion of $18 \mathrm{Gm}$. and a white blood cell count of 19,200 cells per $\mathrm{cu}$. $\mathrm{mm}$. with 24 per cent polymorphonuclear cells, 64 per cent band forms and 6 per cent metamyelocytes. Venous pressure was $90 \mathrm{~mm}$. saline at the level of the right auricle. An electrocardiogram did not differ from previous tracings. Blood urea nitrogen was $20 \mathrm{mg}$. per cent, and the venous carbon dioxide combining power $22 \mathrm{mM}$ per L. A sputum smear revealed moderate numbers of leukocytes and rare gram-positive cocci. Only a rare colony of pneumococci plus normal pharyngeal flora were grown on culture. The initial chest roentgenogram, shown in Figure 17, revealed an extensive, bilateral, diffusely nodular infiltrate fanning peripherally from the hilar regions. A fusiform shadow seen in the right mid-lung field was believed to represent an interlobar effusion in the right horizontal fissure. This had been present in roentgenograms taken prior to the present illness.

The patient's course is depicted in Figure 18. He was placed in an oxygen tent, and treatment with penicillin, streptomycin and chloramphenicol was inititated. The administration of morphine sulfate, digitoxin, diuretics, aminophyllin and Vaponephrine ${ }^{\circledR}$ by nebulizer did not notably improve his respiratory distress. The patient's

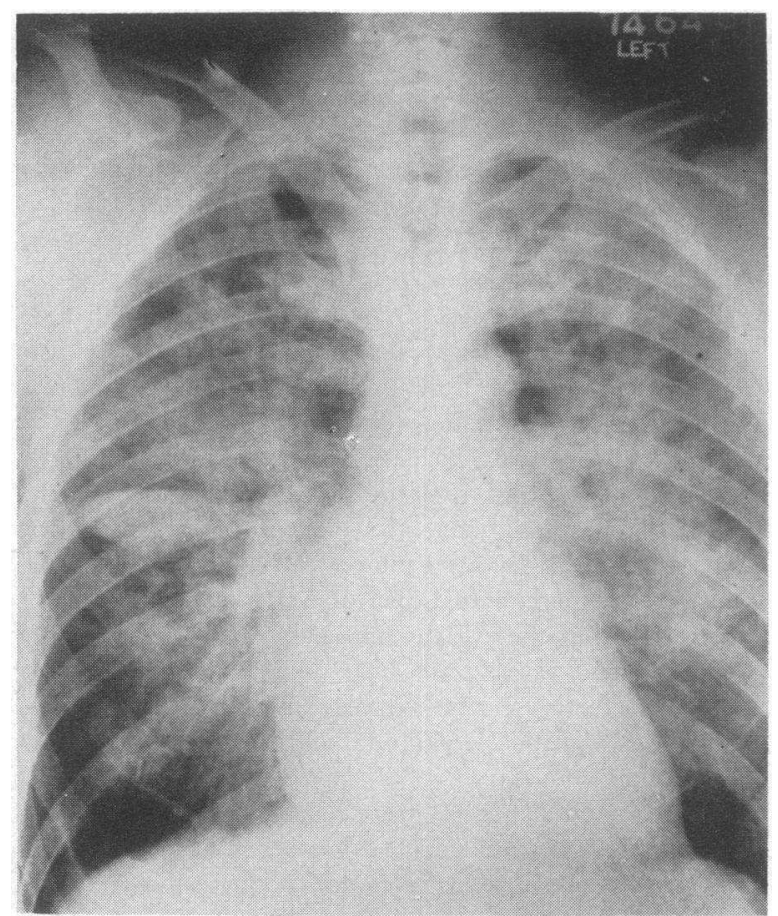

Fig. 17. Admission Chest Roentgenogram on Patient G. H., a 49 Year Old Man with Primary Influenza Pneumonia Superimposed upon Rheumatic Heart Disease with Mitral Stenosis and InsuffiCIENCY

The density in the right mid-lung field represents a loculated interlobar effusion which was present prior to the acute illness. temperature rose to $40.9^{\circ} \mathrm{C}$. and pulmonary rales increased bilaterally. During the second 24 hours he showed transient improvement, but this was followed by steady deterioration. Inspiratory rales were gradually replaced by expiratory rales, low-pitched grating rhonchi and coarse breath sounds of diminished intensity. Cyanosis was progressive and dyspnea became unbearable. The patient became extremely agitated and was unable to tolerate an oxygen mask of any sort except for two to three minutes at a time. Seventy-two hours after admission his blood pressure became unobtainable. Despite intensive therapy, which included hydrocortisone and levarterenol, the patient died on the fourth hospital day.

Findings at autopsy (Autopsy No. 17247). The significant postmortem findings were confined to the lungs and heart. The heart weighed $600 \mathrm{Gm}$. and showed changes characteristic of rheumatic heart disease with severe mitral stenosis. The mitral valve was thickened and stenotic. The aortic valve cusps were rigid and thickened. The chambers of the heart were dilated and the right and left ventricles were hypertrophied. The left auricular appendage contained a well-organized mural thrombus. Multiple sections of the heart examined microscopically showed no evidence of myocarditis.

The lungs were intensely engorged and failed to collapse when the chest was opened. Their combined weight was $4,000 \mathrm{Gm}$. The trachea and bronchi contained much foamy, blood-stained fluid, and the underlying mucosa was markedly hyperemic and exhibited many focal ulcerations. The parenchyma throughout all lobes was dark red and subcrepitant, and large amounts of thin, bloodtinged fluid flowed from the cut surface.

On microscopic examination the mucosa of the trachea and major bronchi was focally ulcerated or covered only by a low cuboidal epithelium. The submucosa in such areas showed marked vascular congestion, focal hemorrhages, edema and a diffuse but scanty infiltration with lymphocytes, plasma cells and neutrophils. The process was patchy, however, and some bronchi were lined by ciliated epithelial cells that appeared essentially normal.

In the parenchyma of the upper lobes the chief alterations consisted of hyperemia of alveolar capillaries, focal alveolar hemorrhages, and a very prominent thick, acellular hyaline membrane that covered the surfaces of the majority of the alveoli and alveolar ducts (see Figure 8). Many alveoli were filled with a pink, granular precipitate admixed with strands of fibrin, a moderate number of erythrocytes and neutrophils, and many histocytes containing hemosiderin or carbon particles. The ciliated epithelium of the small bronchi in the upper lobes appeared essentially normal.

In the lower lobes abnormalities were similar but more marked (see Figure 9). Many small bronchi were ulcerated or covered by a low cuboidal epithelium which exhibited considerable numbers of mitoses. In some areas, many alveoli contained large numbers of neutrophils and hemorrhage was more widespread. Bacteria could not be demonstrated in multiple sections specially stained by the Gram and Giemsa methods. 


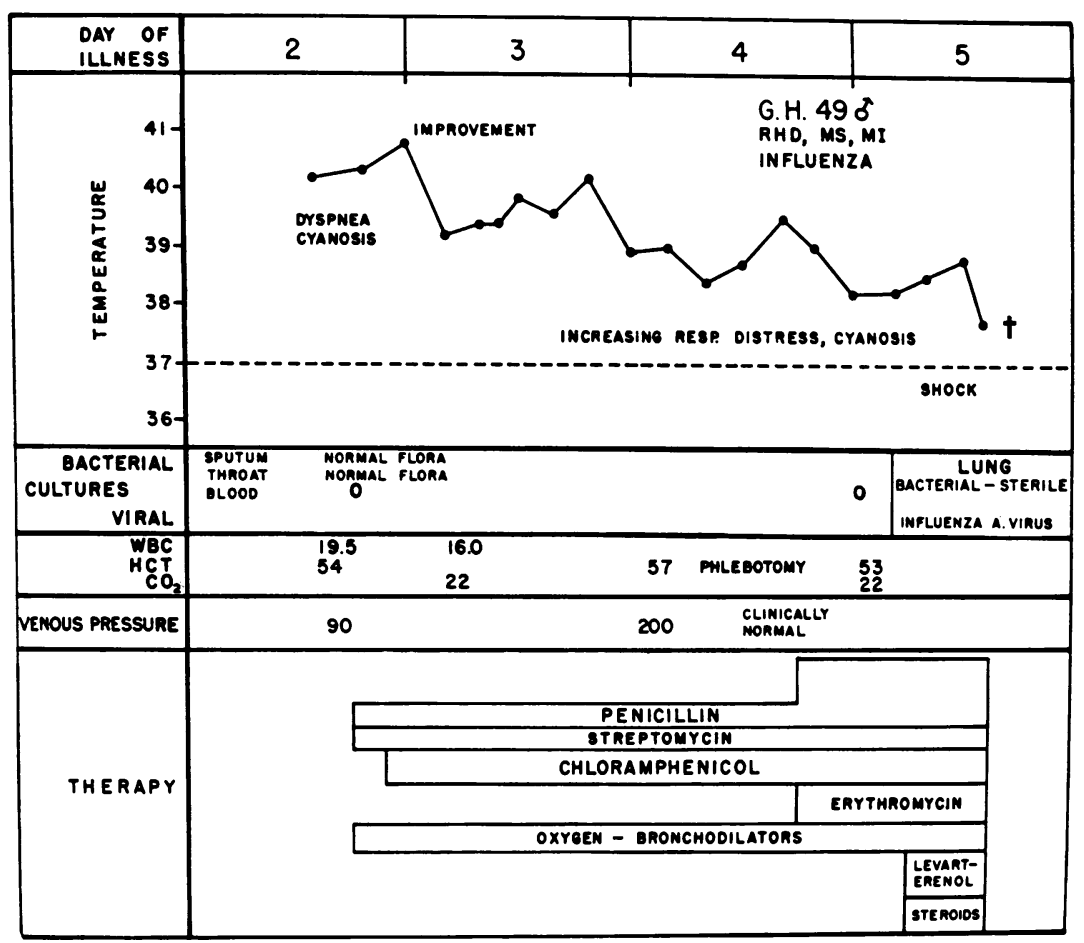

Fig. 18. Course of Illness in Patient G. $\mathrm{H}$.

Bacteriologic cultures performed independently in two laboratories failed to reveal growth of bacteria. Influenza $A$ virus of the Asian type was recovered from lung tissue in concentrations of $10^{5.3}$ infective virus particles per $\mathrm{Gm}$.

Examination of the brain failed to show encephalitis or other unusual changes.

2. C. P., NYH 667901. A 47 year old white man was admitted to the hospital on Oct. 11, 1957, with fever and rapidly progressing dyspnea. The patient had known rheumatic heart disease with predominating mitral insufficiency of many years duration. Chronic exertional dyspnea and orthopnea had been present for at least five years. The day prior to admission the patient developed fever, shaking chills, headache, myalgia and a severe nonproductive cough. During the night his cough became productive of thick, white sputum, and he developed marked respiratory distress for which he was admitted to the hospital.

Physical examination revealed an acutely ill, cyanotic man in severe respiratory distress. The admission temperature was $39.5^{\circ} \mathrm{C}$., heart rate 128 beats per minute, respirations 38 per minute, and blood pressure 130/80 $\mathrm{mm}$. Hg. The neck veins were not distended. Percussion of the chest revealed no local areas of dullness. Fine, moist rales were heard throughout the chest accompanied by diffuse inspiratory and expiratory wheezes. Coarse, sticky, inspiratory rales were present at the right base. The heart was grossly enlarged to percussion, and loud apical systolic and diastolic murmurs were noted. There was no peripheral edema.
The white blood cell count obtained on admission was 15,300 cells per cu. mm. with 82 per cent mature polymorphonuclear cells and 18 per cent band forms. The hematocrit was 49 per cent; the erythrocyte sedimentation rate $14 \mathrm{~mm}$. per hour. Urinalysis gave a 4 plus test for protein; the carbon dioxide combining power was 29 $\mathrm{mM}$ per L. Venous pressure was $120 \mathrm{~mm}$. saline at the level of the right auricle. An electrocardiogram revealed no changes from previous tracings.

Examination of stained sputum smears failed to reveal any predominating microorganisms. Sputum cultures yielded a sparse, mixed flora in which a few colonies of Diplococcus pneumoniae, Pseudomonas pyocyaneus, and Proteus vulgaris could be identified. Blood cultures were sterile. The initial chest roentgenogram, shown in Figure 19, demonstrated a greatly enlarged heart and a diffuse, bilateral infiltrate radiating from the hilum which was compatible with either a diffuse pneumonitis or acute pulmonary edema.

The patient was given oxygen by mask, and penicillin, streptomycin and erythromycin were administered. Digitalization was increased and aminophyllin was given intravenously without significant improvement in the pulmonary findings. Because of the patient's profound air hunger, attempts were made to administer oxygen via a positive pressure mask or the IPPB mask, but the patient became markedly agitated and extremely weak with either mask and would not tolerate such therapy. The morning after admission he became rapidly worse, developed increasing respiratory distress and cyanosis, and his blood pressure fell to shock levels. $\mathrm{He}$ was placed 


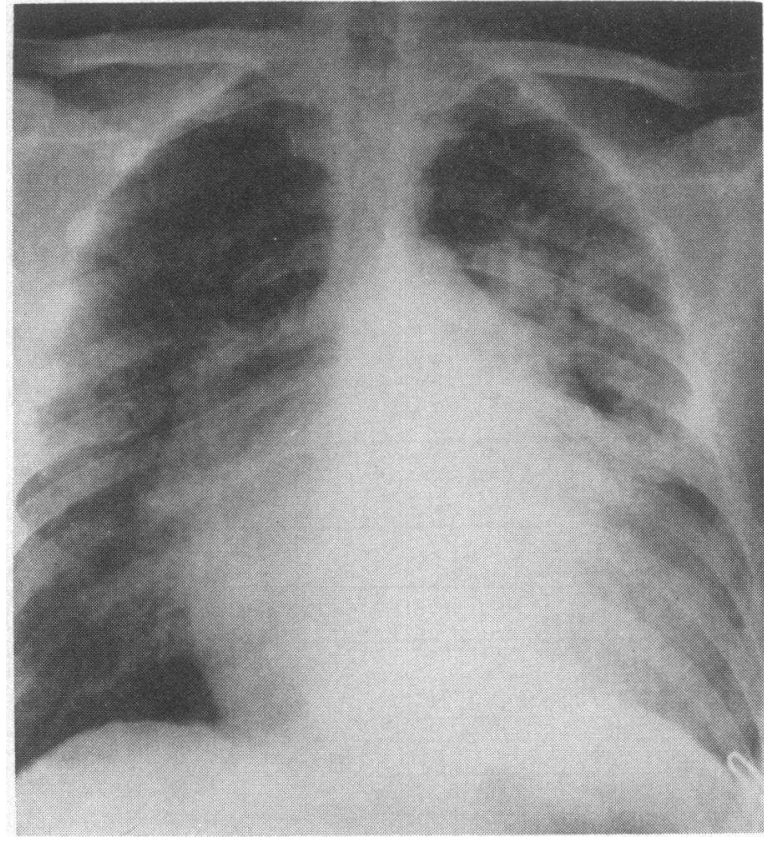

Fig. 19. Admission Chest Roentgenogram on Patient C. P., a 47 Year Old Man with Primary InFLUENZA Virus PNEUMONIA SUPERIMPOSEd UPON RHEUmatic Heart Disease with Mitral Insufficiency

on levarterenol and was given $500 \mathrm{mg}$. of hydrocortisone intravenously. The patient became progressively more hypoxic and cyanotic, had a convulsion and died approximately 60 hours after the onset of his illness.

Findings at autopsy (Autopsy No. 17257). The principal findings were confined to the heart and lungs. The heart weighed $650 \mathrm{Gm}$. and showed changes characteristic of rheumatic heart disease with involvement of the mitral, aortic and tricuspid valves. The mitral valve appeared grossly incompetent because of shortening and fusion of the chordae tendineae and thickening of the leaflets at the line of closure. The aortic valve showed shortening of the left cusp and fusion of the commissures of the posterior and left cusps. The tricuspid valve was thickened along the lines of closure. There was marked hypertrophy and dilatation of both ventricles. The pericardial cavity was obliterated by fibrous adhesions. Microscopic sections of the heart showed a few areas of focal fibrosis but no other unusual changes.

The combined weight of the lungs was $2,100 \mathrm{Gm}$. and the parenchyma was diffusely firm, noncrepitant, and dark red. The trachea and major bronchi contained much blood-stained mucus, and the bronchus to the left upper lobe was plugged with bloody mucus. The cut section of the lungs revealed numerous dark red nodular areas of hemorrhage. The pulmonary arteries and veins appeared grossly normal in hemorrhagic area and were devoid of thrombi.

On microscopic examination the mucosa of the trachea and larger bronchi was focally denuded or ulcerated. In a few areas only the basal cell layer of the mucosa remained. The blood vessels of the submucosa were markedly hyperemic, and the interstitial tissue was edematous and infiltrated with many lymphocytes and plasma cells and lesser numbers of neutrophils. Many of the smaller bronchi contained plugs composed of mucus and neutrophils.

The alveolar capillaries were engorged with erythrocytes and there were numerous focal areas of alveolar hemorrhage. Many of the alveolar spaces contained a pink granular precipitate and small strands of fibrin. Only a small number of alveolar walls were covered by hyaline membranes. The alveolar spaces of the upper lobes contained considerable numbers of hemosiderinladen macrophages and only a few neutrophils, while in the lower lobes exudation of neutrophilic leukocytes was more marked, as shown in Figure 10. The mucosa of many of the smaller bronchi was ulcerated and there was necrosis of adjacent alveolar walls and hemorrhage with a moderate interstitial edema. No unusual changes were noted in the brain or other viscera.

Numerous sections of various lobes were stained by Gram's method and bacteria could not be demonstrated. Multiple cultures of lung tissue showed no bacterial growth on prolonged incubation. The Asian strain of influenza $\mathrm{A}$ virus was recovered from lung tissue in concentrations of $10^{5.7}$ infectious units per $\mathrm{Gm}$.

3. A. B., NYH 757624. A 45 year old white man with rheumatic mitral insufficiency and aortic stenosis was admitted on Oct. 13, 1957, with fever and rapidly increasing dyspnea. For one year prior to admission the patient had noted exertional dyspnea and mild orthopnea. One and one-half days prior to admission he had developed fever, bifrontal headache, generalized myalgia, a moderate sore throat and a nonproductive cough. On the ensuing day he noted rapidly progressing respiratory distress which caused him to seek admission.

Examination revealed a cyanotic, dyspneic man who was acutely ill. His admission temperature was $40^{\circ} \mathrm{C}$., pulse 104 beats per minute, respirations 36 per minute, and blood pressure $120 / 80 \mathrm{~mm}$. $\mathrm{Hg}$. The pharynx was moderately injected. Venous distention was not present. Examination of the chest revealed no local signs of consolidation. Bilateral sticky, inspiratory rales were present at both bases and harsh breath sounds were present throughout both lung fields. The heart was moderately enlarged, and apical and aortic systolic murmurs were present. No hepatomegaly or peripheral edema were noted. The remainder of the physical examination was within normal limits.

The initial white blood cell count was 13,500 cells per cu. $\mathrm{mm}$. with 78 per cent mature polymorphonuclear cells and 10 per cent band forms. The erythrocyte sedimentation rate was $14 \mathrm{~mm}$. per hour. Urinalysis revealed a 3 plus test for protein. Peripheral venous pressure was 120 $\mathrm{mm}$. saline at the level of the right auricle, and an Evans blue dye blood volume determination was normal. An electrocardiogram taken on the day of admission was considered normal. 
Examination of stained sputum smears revealed no predominating microorganisms. Throat and sputum cultures yielded only normal pharyngeal flora with occasional colonies of pneumococci and rare colonies of Hemophilus influenzae. Blood cultures were sterile. The admission chest roentgenogram, shown in Figure 20, demonstrated cardiac enlargement which had not changed from previous examinations. There were bilateral diffuse nodular infiltrations compatible with a diffuse pneumonitis or pulmonary edema. A loculated effusion in the right transverse fissure was noted.

The patient was placed in an oxygen tent and penicillin, streptomycin and erythromycin were administered. The patient's condition gradually deteriorated during the first 24 hours. Temperature remained at $40^{\circ} \mathrm{C}$. and could not be reduced with large doses of aspirin. Conventional therapy of acute pulmonary edema produced no change in his condition. The respiratory rate rose to 64 per minute and cyanosis deepened. Diffuse inspiratory and expiratory rales increased. Oxygen administered via the IPPB apparatus was tolerated poorly because of agitation and increasing claustrophobia.

At this time hydrocortisone, $100 \mathrm{mg}$., was given intravenously. The patient improved transiently with marked clearing of the pulmonary rales. However, within six hours his respiratory rate again rose to 64 per minute and cyanosis and agitation increased. Progressive expiratory difficulties were noted and coarse rales, grating rhonchi and harsh breath sounds were heard throughout the lung fields. Venous pressure determined at this

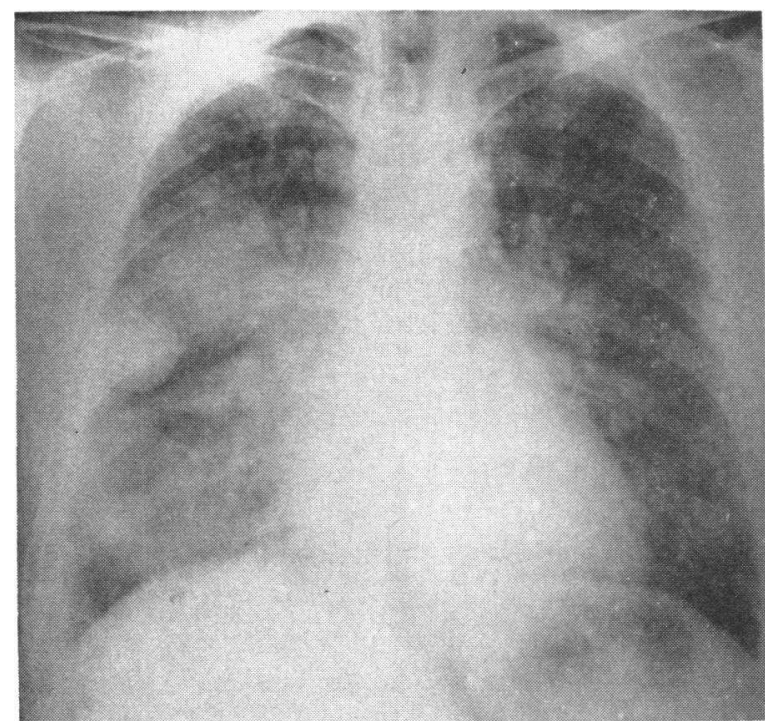

Fig. 20. Admission Chest Roentgenogram on Patient A. B., a 45 Year Old Man with Influenza Virus Pneumonia Superimposed upon Rheumatic Heart Disease with Aortic Stenosis and Mitral INSUFFICIENCY

The density in the right mid-lung field represents an interlobar effusion. time was $65 \mathrm{~mm}$. saline. Again intravenous hydrocortisone was administered, with transient clearing of pulmonary signs. Nevertheless, respirations became increasingly labored and the patient died 40 hours after hospitalization.

An autopsy was not performed on this patient. However, needle aspirates of lung were obtained post mortem and were sterile on bacteriologic culture. Influenza A virus of the Asian type was recovered from a throat washing obtained on Day 2 of the illness and also from pulmonary tissue obtained after death in a concentration of $10^{4} \mathrm{egg}$ infectious units per $\mathrm{Gm}$.

Comment. Each of these three patients had severe rheumatic heart disease. Each entered the hospital within 36 hours after the onset of a typical influenza-like illness with fever and rapidly progressive difficulties in breathing. In each case, the findings on initial physical examination and chest roentgenograms were interpreted as being compatible with pulmonary edema of cardiac origin. The absence of venous distention, the presence of normal venous pressures, the striking fever and the failure of the patient to respond to treatment for congestive failure suggested that the illness was primarily a manifestation of intrinsic pulmonary disease rather than myocardial decompensation.

Each patient had a rapid down-hill course characterized by sustained fever, increasing cyanosis and air hunger. Marked agitation developed, and measures required to obtain adequate oxygenation could not be tolerated. There was no response to massive antimicrobial therapy and death in all three ensued within 96 hours after hospitalization. At autopsy the lungs showed destructive changes characterized by pulmonary hyperemia and hemorrhages, alveolar hyaline membranes, and focal ulceration of the trachea and bronchi. Postmortem bacterial cultures were uniformly sterile, and influenza $A$ virus (Asian strain) was recovered in high concentration from samples of lung tissue obtained post mortem.

4. P. B., NYH 420164. A 45 year old white man was admitted on Oct. 14, 1957, because of fever and increasing dyspnea. The patient had known rheumatic heart disease of long standing. Six years prior to admission he had undergone mitral valvulotomy and had remained relatively free of cardiac symptoms since that time. The day prior to admission the patient noted the onset of sore throat, fever, a nonproductive cough, diffuse myalgia, nausea and a scratchiness of his eyes. Over the next 12 hours fever persisted. His cough became pro- 
ductive of blood-tinged sputum, and he noted increasing difficulty in breathing.

Admission physical examination revealed a dyspneic, cyanotic, agitated man who was acutely ill. The temperature was $40.4^{\circ} \mathrm{C}$., heart rate 110 beats per minute, respirations 38 per minute, and blood pressure 150/80 $\mathrm{mm} . \mathrm{Hg}$. The conjunctivae were mildly injected. There was no venous distention. Examination of the chest revealed no signs of consolidation, but breath sounds were markedly decreased throughout and a few bilateral inspiratory basilar rales were noted. The heart was enlarged and auricular fibrillation was present. A blowing systolic murmur and a soft mid-diastolic murmur were noted at the apex. There was no hepatomegaly or peripheral edema.

Initial white blood cell count was 13,700 cells per cu. $\mathrm{mm}$. with 71 per cent polymorphonuclear cells and 18 per cent band forms. The hematocrit was 44 . Urinalysis showed a 4 plus test for protein. Admission carbon dioxide combining power was $30 \mathrm{mM}$ per $\mathrm{L}$. A venous pressure performed with difficulty on admission was 160 $\mathrm{mm}$. saline, but a blood volume determination simultaneously performed was normal. An electrocardiogram was not significantly different from previous tracings. Arterial oxyhemoglobin saturation was 84.8 per cent and the arterial blood $\mathrm{pH}$ was normal.

Sputum smears revealed only sparse bacteria, and sputum cultures yielded normal pharyngeal flora with rare colonies of pneumococci and Hemophilus influenzae.

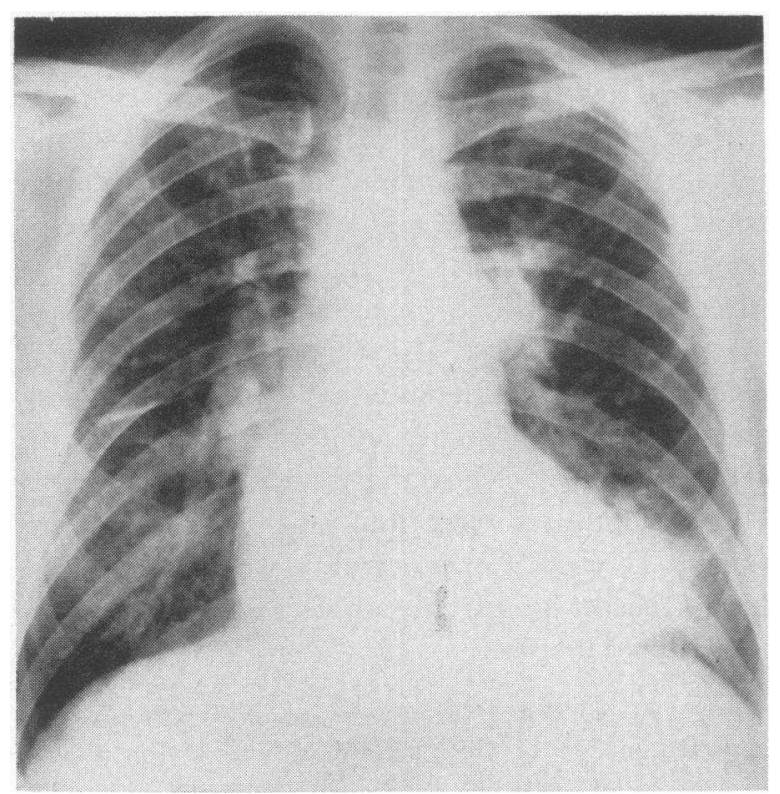

Fig. 21. Admission Chest Roentgenogram on Patient P. B., a 45 Year Old Man with Primary Influenza Virus Pneumonia Superimposed upon Rheumatic Heart Disease with Mitral Stenosis

A mitral valvulotomy was performed on the patient six years prior to the present admission at which time the anterior portion of the fourth rib was resected.
Blood cultures were sterile. The admission chest roentgenogram showed patchy pneumonic densities extending from the hila toward both lower lung fields (Figure 21).

The hospital course is illustrated in Figure 22. The patient was given penicillin, 2.4 million units; streptomycin, $2 \mathrm{Gm}$.; and erythromycin, $2 \mathrm{Gm}$. daily. In addition, mercurial diuretics and digitalis were administered, and prednisone, $200 \mathrm{mg}$. daily, was started. Oxygen was administered by tent or nasal catheter alternating with the IPPB mask. Vaponephrine ${ }^{\circledR}$ and Alevaire ${ }^{\circledR}$ were intermittently aerosolized through the mask.

During the first three days of hospitalization the patient appeared to improve. His fever diminished, pulmonary signs lessened and arterial oxygen saturation rose to 91.8 per cent. However, on the fourth day the patient became worse. His temperature rose to $39.2^{\circ} \mathrm{C}$., the respiratory rate increased to 44 per minute, and the patient was increasingly disoriented and apprehensive. Examination of the lungs at this time revealed suppression of breath sounds and marked inspiratory and expiratory moist rales, and wheezes were noted throughout the chest. The patient, although extremely restless, tolerated oxygen via the IPPB mask extremely well, and arterial oxygen saturation could be maintained at almost normal levels. Nevertheless, there was evidence of increasing respiratory acidosis.

On the seventh hospital day the arterial $\mathrm{pCO}_{2}$ had reached $76 \mathrm{~mm}$. Hg. Serum bicarbonate had risen concomitantly to $37.2 \mathrm{mEq}$. per $\mathrm{L}$. At this time acetazolamide, $0.5 \mathrm{Gm}$. every 12 hours, was administered. During the next 24 hours the patient had a diuresis of 3,000 $\mathrm{ml}$. of urine. His serum bicarbonate and carbon dioxide combining power fell to a normal range and abnormal pulmonary findings decreased.

During the remaining weeks of hospitalization the patient's inspiratory and expiratory wheezes and rales gradually disappeared and breath sounds became normal. Influenza virus was not demonstrated in a throat washing taken on Day 2 of illness, but convalescent serums showed a 16-fold rise in complement fixing and hemagglutinating antibody titers against the Asian strain of influenza A virus.

Comment. This case represents the only patient who recovered in the group of six patients believed to have primary influenza virus pneumonia. The history, physical findings and initial course were in every way similar to other patients in this group. Although influenza virus was not isolated from the initial throat washing, there was a diagnostic rise in complement fixing and specific hemagglutination-inhibiting antibody titer during the illness. No evidence of concomitant bacterial infection was obtained.

Although the reasons for this patient's survival are not known, two factors may have contributed to his recovery. First, in contrast to the remaining 


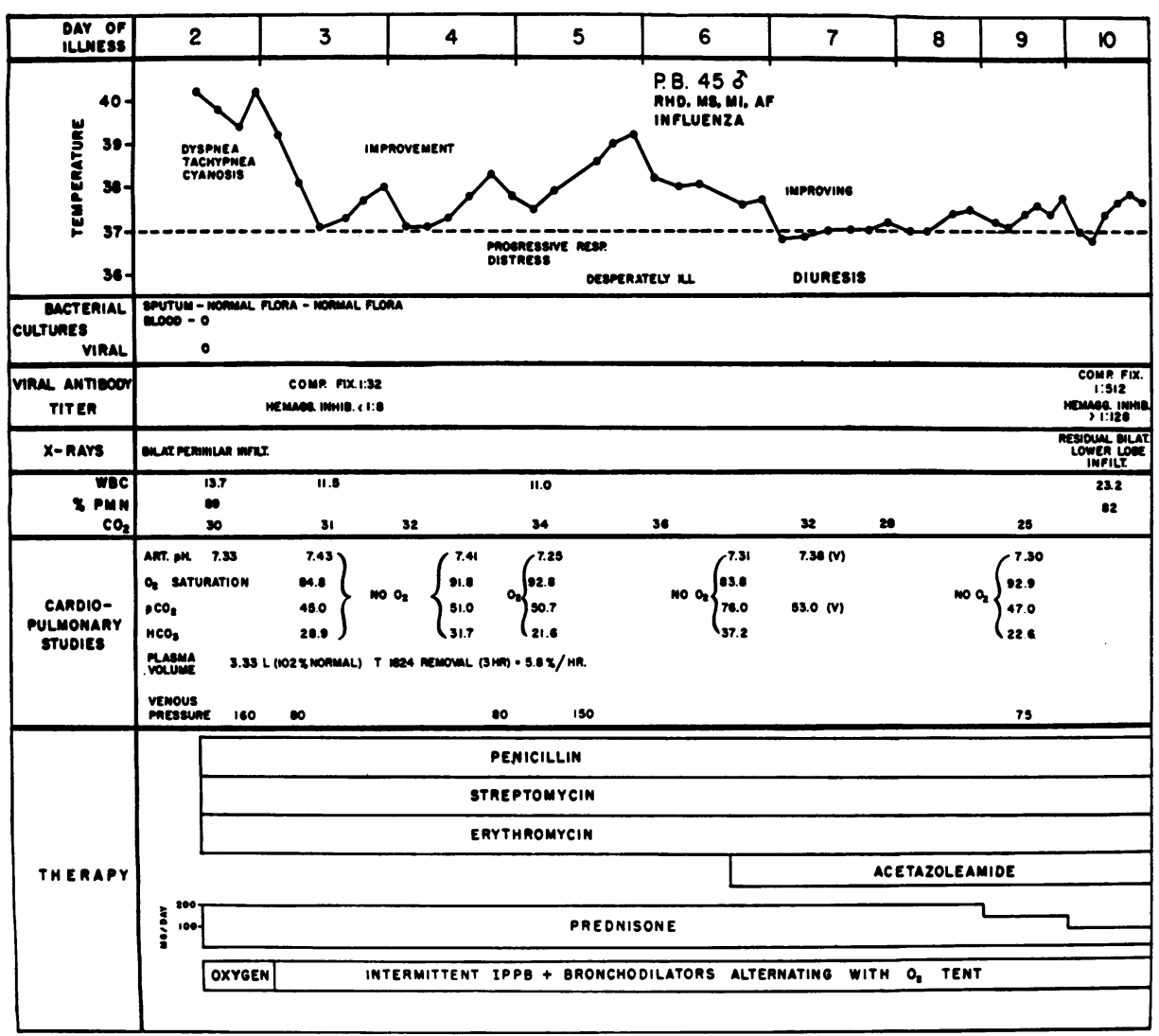

Fig. 22. Course of Illness in Patient P. B.

patients in this group, this patient was able to tolerate oxygen administered via the IPPB mask for long periods and maintained his arterial oxygen saturation at almost normal levels. Secondly, a diuresis occurred in association with the administration of acetazoleamide. Clearing of pulmonary signs and the return of arterial $\mathrm{pCO}_{2}$ and serum bicarbonate to normal levels were temporally associated.

5. J. B., NYH 779866. A 75 year old white woman was admitted on Oct. 15, 1957, with fever, intense cyanosis and coma. An inadequate history from relatives indicated that one day prior to admission the patient had developed fever which was followed by dyspnea and orthopnea.

Physical examination revealed an intensely cyanotic, comatose, elderly woman with rapid, labored respirations. Admission temperature was $39.2^{\circ} \mathrm{C}$, , heart rate 108 beats per minute, respirations 54 per minute, and blood pressure $180 / 80 \mathrm{~mm}$. Hg. Despite the obvious dyspnea, neck veins were not distended. Examination of the chest revealed only diffuse inspiratory rales throughout both lung fields without evidence of local consolidation. The heart was minimally enlarged and a loud, harsh systolic murmur was heard along the left sternal border and at the apex. The liver was not enlarged. There was no peripheral edema.

Initial laboratory studies revealed a white blood cell count of 15,700 cells per cu. mm. with 79 per cent polymorphonuclear cells and 15 per cent band forms. Urinalysis gave a one plus test for protein. Examination of the sediment revealed 8 to 10 white blood cells per high power field. A determination of venous carbon dioxide combining power was $18 \mathrm{mM}$ per L. Peripheral venous pressure was $94 \mathrm{~mm}$. saline. The electrocardiogram showed changes suggestive of left ventricular hypertrophy. A blood volume determination performed on the first hospital day was minimally elevated (118 per cent of calculated normal).

Cultures of sputum, nasopharyngeal and throat secretions yielded only normal pharyngeal flora, and blood cultures were sterile. A throat washing taken on admission revealed the Asian strain of influenza A virus. The admission chest roentgenogram revealed dense pulmonary infiltrations involving the lower half of both lung fields and a prominent hilar fan which was interpreted as vascular congestion.

Because of the similarity of this patient's illness to the cases already described, it was believed that this illness probably represented influenza, and treatment was insti- 
tuted accordingly. Digitalization, the administration of morphine sulfate, rotating tourniquets, intravenous aminophyllin, diuretics and positive pressure oxygen via the IPPB apparatus did not produce notable improvement. Penicillin, 6 million units; streptomycin, $2 \mathrm{Gm}$.; chloramphenicol, $2 \mathrm{Gm}$; and hydrocortisone, $200 \mathrm{mg}$. daily, were given.

The patient's course is depicted in Figure 23. On the program outlined, her temperature returned to normal over a 48 hour period and the respiratory rate decreased to 25 to 30 per minute, but pulmonary findings of rales, rhonchi and expiratory prolongation persisted at the lung bases. Arterial oxygen saturation was difficult to maintain. Serial arterial blood gas studies were performed which are included in Tables IX and XIII and Figure 23. Without supplemental oxygen, arterial oxyhemoglobin saturation was 46.2 per cent on admission and never rose above 73.5 per cent during hospitalization. However, the administration of oxygen under pressure consistently brought oxyhemoglobin saturation to above 90 per cent. There was little evidence that the $\mathrm{pCO}_{2}$ could be reduced by any mechanical breathing aid. A respiratory acidosis was generally maintained, and superimposed metabolic acidosis gradually developed as the blood urea nitrogen rose. Blood ketones were elevated to $142 \mu \mathrm{Eq}$. per L., and blood pyruvate was increased to $164 \mu \mathrm{Eq}$. per L. on the one determination performed.

In view of the continuing coma, lumbar puncture was performed. There were no abnormalities of protein, sugar or cells, and influenza virus could not be recovered from the cerebrospinal fluid. The blood urea nitrogen gradually rose to a maximum of $83 \mathrm{mg}$. per cent. On the ninth day of disease the patient aspirated food and pharyngeal secretions; respiratory findings increased and coma deepened. She expired on the eleventh day of illness.

Findings at autopsy (Autopsy No. 17278). The principal abnormalities were confined to the heart and lungs. The heart weighed $500 \mathrm{Gm}$. and showed changes characteristic of hypertensive cardiovascular disease. The left ventricle was hypertrophied, 'measuring $15 \mathrm{~mm}$. in thickness at the base. The coronary arteries were patent but their lumina were focally narrowed by fibrous and fatty plaques. Microscopic examination revealed focal myocardial fibrosis without evidence of active myocarditis.

The lungs were hemorrhagic, subcrepitant, and together weighed $1,600 \mathrm{Gm}$. The mucosa of the trachea and bronchi was markedly hyperemic. The lung parenchyma

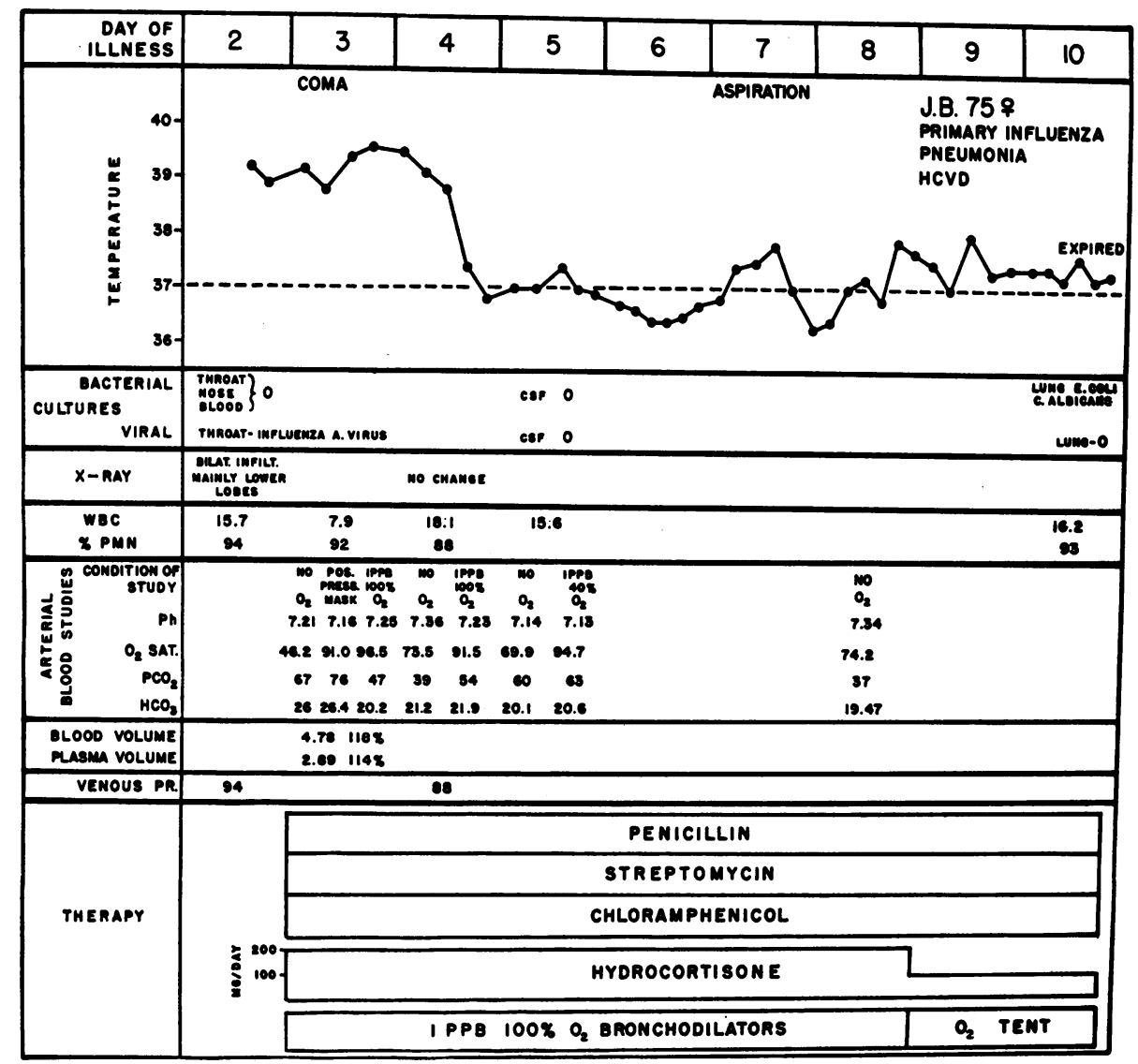

Fig. 23. Course of Illness in Patient J. B., a 75 Year Old Woman with Primary Influenza Virus Pneumonia Superimposed upon Hypertensive Heart Disease 
was dark red to purple, and a frothy fluid could be readily expressed from the cut surfaces. Numerous nodular areas of consolidation ranging up to $1 \mathrm{~cm}$. across were present in the entire right lung and to a lesser degree in the left lower lobe. Elsewhere the lung was well aerated.

Microscopic examination showed that only the mucosa in the deeper folds of the trachea remained, and even here the normal mucosa was replaced by low cuboidal cells. The submucosal vessels were markedly hyperemic and the interstitial tissues were edematous and infiltrated with moderate numbers of lymphocytes, plasma cells and a few neutrophils. The mucosa of the small bronchi was frequently lined by squamous epithelial cells which showed marked variation in size, shape and staining quality. A number of these cells were in mitosis.

Throughout the lung parenchyma the alveolar capillaries were engorged with red blood cells. The alveolar spaces contained a pink, granular precipitate and varying amounts of fibrin. Focal hemorrhages were present, and in many areas hyaline membranes covered the walls of the alveoli and alveolar ducts. In the upper lobes there were moderate numbers of histiocytes and a few neutrophilic leukocytes and lymphocytes within the alveolar spaces. In the lower lobes all of these changes were more marked. In addition, the small bronchi and many of the alveolar spaces contained masses of polymorphonuclear leukocytes. In some of the small bronchi aspirated muscle fibers and other food particles were demonstrated. In these areas gram-positive cocci and budding yeast-like fungi were seen. Permission to examine the brain was not obtained.

Bacteriologic cultures obtained from the lungs post mortem yielded a few colonies of $E$. coli and moderate numbers of Candida albicans. Influenza virus was not recovered from the lung tissue.

Comment. The postmortem findings in this case were those of pneumonia characterized by hemorrhage, edema and hyaline membrane formation. In addition, there was evidence of aspiration pneumonia which was confined to certain sections of the lower lobes. Influenza A virus was isolated from the throat during life but was not isolated from the lung post mortem. It is probable that the failure to recover the virus at autopsy was related to the prolonged period (11 days) between the onset of illness and death $(7)$.

The early recovery of influenza virus from the throat, the clinical syndrome and the postmortem findings were suggestive of an influenza virus pneumonia complicated preterminally by an aspiration pneumonitis. The possibility of concomitant encephalitis was entertained, but influenza virus could not be recovered from cerebrospinal fluid, and other examinations of the spinal fluid were un- remarkable. Postmortem examination of the brain was not permitted.

6. A. C., NYH 768041. A 66 year old white man was admitted on Oct. 19, 1957, with increasing respiratory difficulties of one day's duration. This patient had known arteriosclerotic heart disease and a history of two previously documented myocardial infarcts. One day prior to admission he had several shaking chills and developed fever, sore throat, muscle aches and a cough productive of greenish sputum. Progressive respiratory distress led to his admission.

Physical examination on admission revealed an acutely ill man with extreme dyspnea and intense cyanosis of the lips and nailbeds. Temperature was $39.2^{\circ} \mathrm{C}$., pulse rate 124 per minute, respirations 40 per minute, and blood pressure $170 / 100 \mathrm{~mm} . \mathrm{Hg}$. Inspiratory rales were heard throughout both lung fields. There was no evidence of pulmonary consolidation. The remainder of the physical examination was within normal limits.

Laboratory studies revealed a white blood cell count of 19,000 cells per cu. mm. with 72 per cent mature polymorphonuclear cells and 14 per cent band forms. The hematocrit was 56 per cent. Urinalysis showed a specific gravity of 1,024 , a 4 plus test for protein, 25 to 50 red blood cells and 3 to 8 white blood cells per high power microscopic fleld. The erythrocyte sedimentation rate was $15 \mathrm{~mm}$. per hour; the serum carbon dioxide combining power was $22 \mathrm{mM}$ per L. Serial electrocardiograms showed no change from previous tracings.

Sputum smears showed no predominance of any bacterium, and sputum and throat cultures yielded only normal pharyngeal flora. Influenza virus with the antigenic characteristics of the Asian strain was recovered from a throat washing. An admission chest roentgenogram showed generalized cardiac enlargement and extensive pulmonary infiltrates which radiated peripherally from the hilar region-a finding consistent with bilateral pulmonary edema or diffuse pneumonitis.

Treatment was instituted with oxygen via positive pressure mask, intravenous aminophyllin, diuretics, digitalis and morphine sulfate. A phlebotomy of $400 \mathrm{ml}$. of blood was performed. Penicillin, 2.4 million units; streptomycin, $2 \mathrm{Gm}$.; and erythromycin, $2 \mathrm{Gm}$., were given daily. Because of continuing cyanosis, the IPPB mask was substituted for the positive pressure mask. The patient's blood pressure fell to $80 / 40 \mathrm{~mm}$. $\mathrm{Hg}$ and levarterenol was added to his regimen. Over the next 24 hours the patient improved markedly. The respiratory rate declined to 30 per minute and cyanosis disappeared. Because the hypotension appeared related to use of oxygen under pressure, the regimen was altered so that 30 minutes of intermittent positive pressure breathing every two hours was alternated with periods in an oxygen tent. The patient's blood pressure stabilized at $130 / 80 \mathrm{~mm}$. $\mathrm{Hg}$ and levarterenol was discontinued. A chest roentgenogram taken 36 hours after admission showed significant improvement.

On the third hospital day the patient had a right sided convulsion followed shortly by a more severe left sided 
seizure. Following the seizures blood pressure was unobtainable and inspiratory and expiratory rales and rhonchi were heard throughout the chest. The patient expired eight hours after his initial convulsion.

Findings at autopsy (Autopsy No. 17274). Significant postmortem findings were confined to the heart and lungs. The heart weighed $490 \mathrm{Gm}$. and showed changes typical of hypertensive and arteriosclerotic cardiovascular disease. There was diffuse sclerosis of the entire coronary system with marked narrowing of the lumina in many areas. Both the right coronary and left circumflex coronary arteries were completely occluded close to their origin. Microscopic sections of the heart revealed extensive fibrosis but no evidence of acute necrosis or myocarditis.

The trachea and major bronchi were extremely hyperemic. The lungs weighed $1,850 \mathrm{Gm}$. The parenchyma was firm, subcrepitant and dark red, and the cut surfaces exuded a small amount of pink frothy fluid. The right and left lower lobes were consolidated, dark red and airless.

On microscopic examination the mucosa of the trachea was largely denuded or covered by low cuboidal cells, but in some areas normal ciliated cells were present. The submucosal vessels were markedly hyperemic and the interstitial tissue was infiltrated with moderate numbers of lymphocytes and plasma cells and a few neutrophilic leukocytes.

Marked vascular congestion and focal hemorrhages were prominent in the upper lobes, and there were large amounts of pink granular material and fibrin within the alveolar spaces. Histiocytes containing hemosiderin or carbon granules and moderate numbers of neutrophilic leukocytes were also present in the alveolar spaces. $\mathrm{Hy}$ aline membranes covered many of the alveolar walls of the upper and right middle lobes.

Congestion of the alveolar capillaries and intra-alveolar edema were more marked in the lower lobes, and in addition the alveoli contained large numbers of polymorphonuclear leukocytes and fibrin. In these lobes the bronchi were frequently ulcerated, and the lumina contained moderate numbers of neutrophilic leukocytes.

Changes suggestive of encephalitis were not seen in sections of the brain.

Bacteria were not seen in sections of the lungs stained by the Gram and Giemsa methods. One postmortem culture yielded two colonies of coagulase negative Staphylococcus albus but other cultures were sterile. Asian influenza $A$ virus was recovered in a concentration of $10^{2}$ egg infectious units $\left(\mathrm{EID}_{\overline{5} 0}\right)$ per $\mathrm{Gm}$. of lung tissue.

Comment. Initially, this patient was believed to have acute pulmonary edema of cardiac origin. His early response to therapy for congestive failure appeared to support this possibility. However, the history obtained later of typical influenza followed by respiratory distress, the high fever, leukocytosis and absence of electrocardiographic changes suggested that influenza virus infection was responsible for the syndrome observed. The subsequent isolation of an influenza virus from the throat and lungs, the absence of bacterial pathogens and the characteristic findings at autopsy indicated that this patient had developed a fulminating influenza virus pneumonia.

\section{Pneumonia of combined infuenza virus and bacterial origin}

Nine patients in the current series had evidence of a progressive bilateral pneumonitis with focal signs of consolidation in which both influenza virus and bacterial pathogens were implicated. The following four cases illustrate this syndrome.

1. E. R., NYH 389976. A 35 year old housewife was admitted on Oct. 17, 1957, with fever, cough and chest pain. There was a past history of asymptomatic rheumatic mitral stenosis. The patient was six and one-half months pregnant. The night before admission she developed a scratchy throat and mild generalized myalgia. At 1:00 a.m. on the day of admission she awoke with headache, experienced two shaking chills, developed left anterior chest pain and noted a cough which was productive of bloody sputum.

Admission physical examination revealed an extremely ill, dyspneic woman who was slightly cyanotic. The temperature was $39.5^{\circ} \mathrm{C}$., the heart rate 120 beats per min-

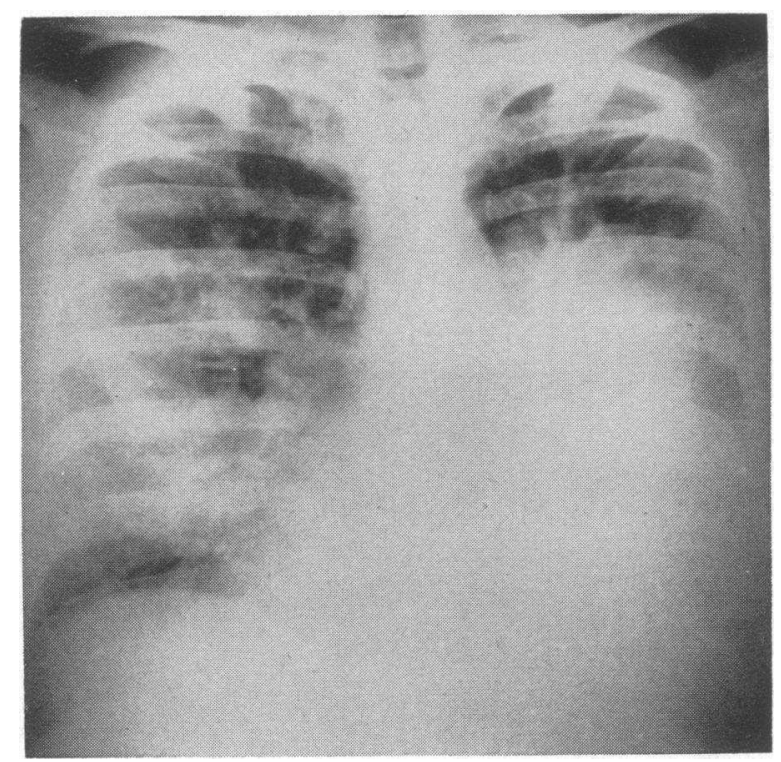

Fig. 24. Admission Chest Roentgenogram on Patient E. R., a 35 Year Old Woman with Concomitant Influenza Virus and Pneumococcal Pneumonia Superimposed Upon Rheumatic Heart Disease with Mitral Stenosis and Pregnancy 


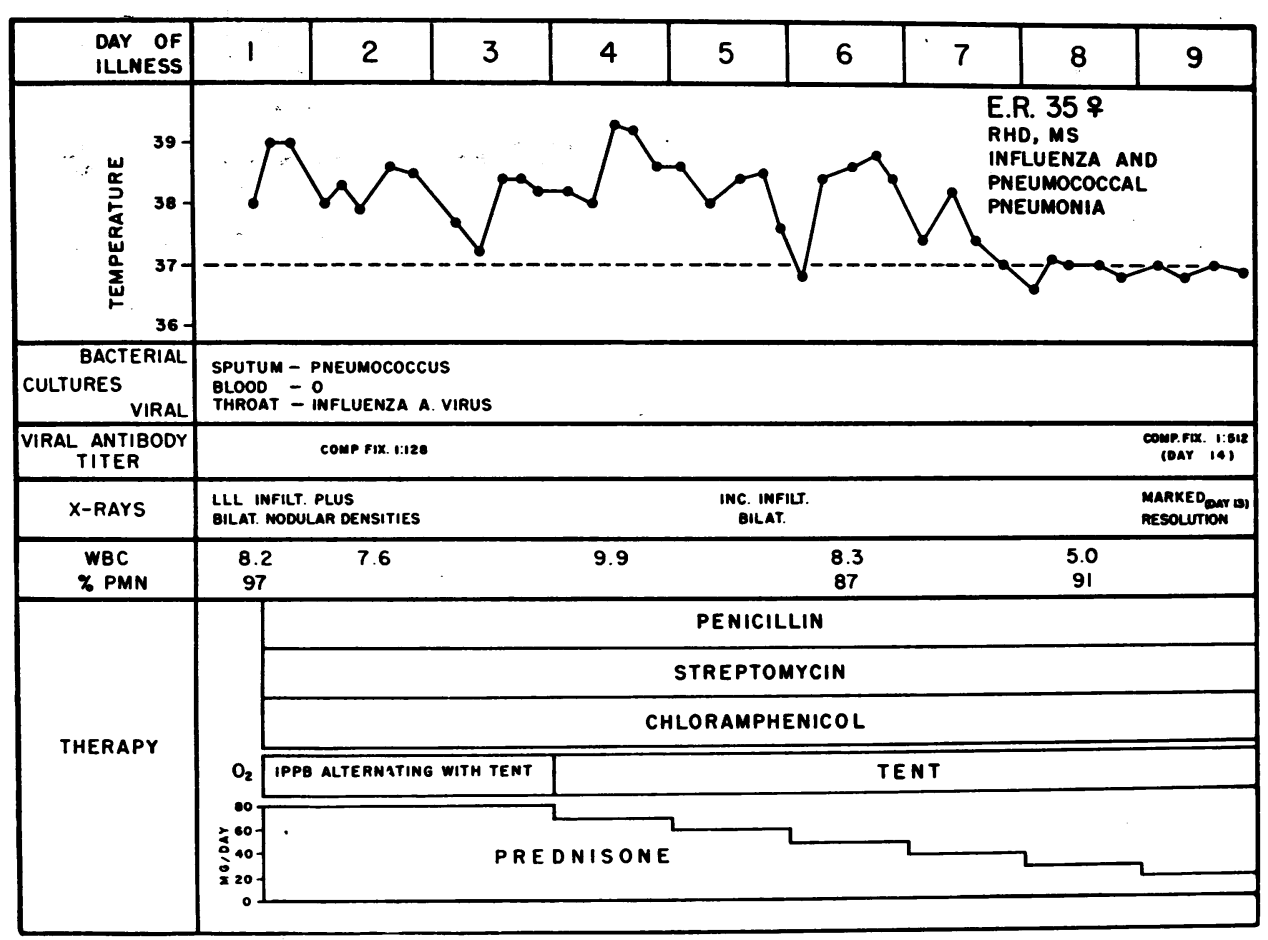

Fig. 25. Course of Illness in Patient E. R.

ute, respirations 44 per minute, and blood pressure 100/60 $\mathrm{mm}$. Hg. No venous distention was present. Classic signs of consolidation were noted over the entire left lower lobe. The heart was slightly enlarged to percussion, and a loud presystolic apical murmur was present. The remainder of the physical examination was within normal limits.

Laboratory studies showed the white blood cell count to be 8,200 cells per cu. $\mathrm{mm}$. with 80 per cent mature polymorphonuclear cells and 17 per cent band forms. The erythrocyte sedimentation rate was $17 \mathrm{~mm}$. per hour. Venous pressure, Decholin circulation time and an electrocardiogram were normal. Examination of stained sputum smears showed many gram-positive diplococci, and sputum cultures yielded many pneumococci. A chest roentgenogram (Figure 24) revealed homogeneous density throughout the left lower lung field with nodular densities extending from the right hilum.

The course of illness is illustrated in Figure 25. The patient was placed on penicillin, streptomycin and chloramphenicol. Prednisone, $80 \mathrm{mg}$. daily, was administered by mouth. Oxygen was administered by tent and the IPPB mask. Physical signs of lobar consolidation cleared rapidly; however, the patient remained exhausted, tachypneic and continued to have a fatiguing cough productive of bloody sputum. Repeated chest roentgenography revealed that the diffuse, nodular bilateral infiltrate had increased as the lower lobe infiltrate had subsided. $\mathrm{Re}$ covery was slow, the patient remaining febrile until the eighth hospital day. A chest roentgenogram taken 11 days after admission showed marked resolution of the bilateral pneumonic process, but residual bilateral nodular infiltrates were still present (Figure 26). She was discharged without abnormal findings 22 days after admission.

Influenza $A$ virus of the Asian type was recovered from a throat washing obtained on admission. Studies of acute and convalescent serum revealed a fourfold rise in complement fixing antibodies diagnostic of influenza.

Comment. This patient with influenza also had single lobe pneumococcal pneumonia which responded to adequate antimicrobial therapy. However, fever, respiratory distress and hemoptysis persisted for more than a week and symptomatic improvement was slow. Chest roentgenography showed clearing of the lobar infiltrate but progression of a bilateral diffuse infiltrate believed to be indicative of viral involvement. This patient was believed to have combined pulmonary infection caused both by influenza virus and the pneumococcus.

2. A. $Z$., $N Y H$ 781886. A 21 year old woman was admitted on Nov. 8,1957 , because of profound respiratory distress. Three days prior to admission she had developed a sore throat, myalgia, bifrontal headache, a dry cough and fever to $103^{\circ} \mathrm{F}$. (oral). She was seen by a physician who noted no respiratory distress or abnormalities on physical examination of the chest. The night 
prior to admission she developed pleuritic right chest pain, tachypnea and dyspnea. On the morning of admission her respiratory distress became increasingly severe. When seen by her physician she was markedly cyanotic and audible bubbling sounds could be heard at considerable distance from the patient.

Physical examination on admission revealed a critically ill, anxious, dyspneic woman who was intensely cyanotic. Her temperature was $40.3^{\circ} \mathrm{C}$., respiratory rate 60 per minute, pulse 160 per minute, and blood pressure $130 / 70$ $\mathrm{mm}$. Hg. The conjunctivae and pharynx were moderately injected. Crackling inspiratory rales and harsh breath sounds were noted throughout both lung fields. Expiration was labored and appeared to be obstructed. There was evidence of consolidation of both lower lobes. The remainder of the physical examination was not remarkable.

Initial laboratory studies showed the white blood cell count to be 2,000 cells per cu. mm. with 58 per cent lymphocytes, 8 per cent monocytes, 7 per cent polymorphonuclear cells, 9 per cent band forms, 13 per cent metamyelocytes and 5 per cent myelocytes. Urinalysis gave a 3 plus test for protein. The electrocardiogram showed generalized depression of the RT segments with decreased amplitude of the $T$ waves. The patient's arterial oxyhemoglobin saturation was reduced to 71.1 per cent.

Sputum was grossly bloody and contained large numbers of gram-positive cocci. Hemolytic Staphylococcus

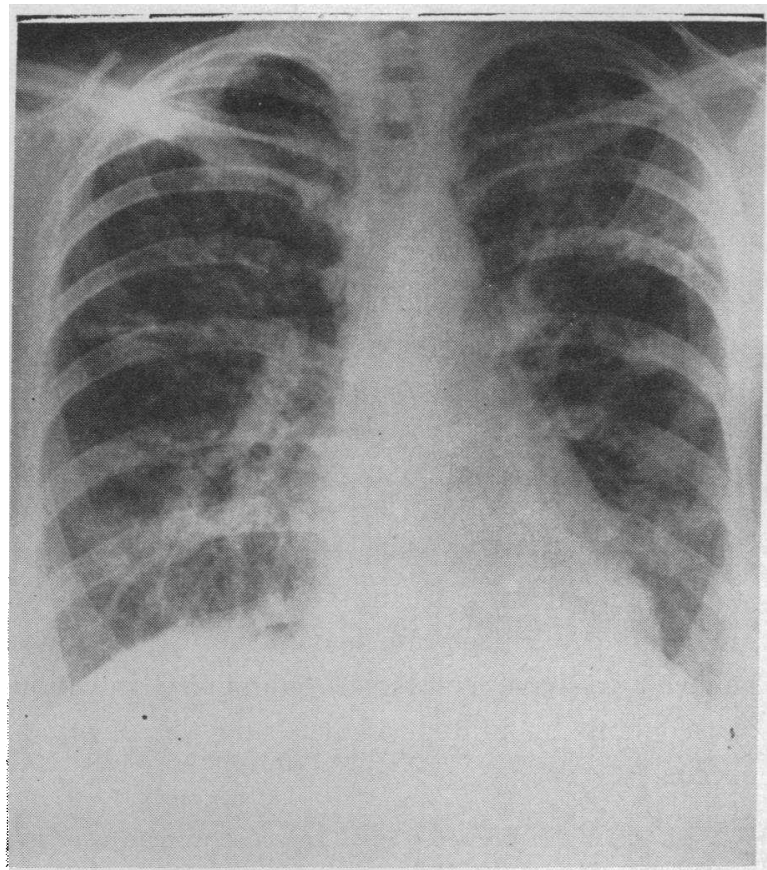

Fig. 26. Chest Roentgenogram on Patient E. R. Taken on Day 11 of Hospitalization

Despite virtually complete clearing of the left lower lobe infiltrate, patchy nodular infiltrates remain visible in all lobes.

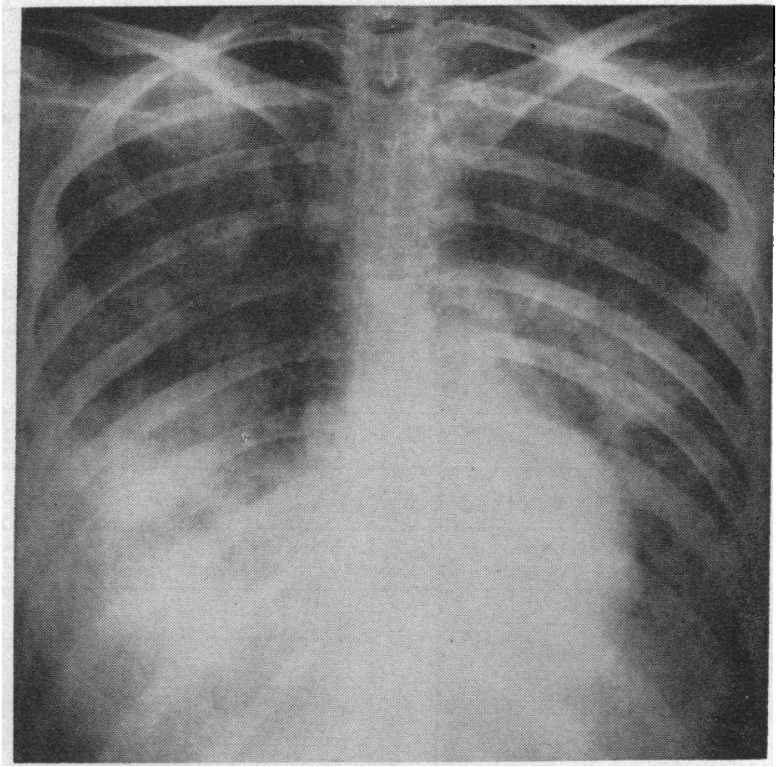

Fig. 27. Admission Chest Roentgenogram on Patient A. Z., a 21 Year Old Woman with Influenza Virus and Staphylococcal Pneumonia

aureus (international bacteriophage type 80/81) was grown in pure culture from the sputum. This organism was sensitive to erythromycin, chloromycetin, streptomycin and novobiocin, but resistant to penicillin and the tetracyclines. The Asian strain of influenza A virus was recovered from throat washings. The admission chest roentgenogram, shown in Figure 27, revealed dense bilateral lower lobe infiltrates with scattered nodular densities present in the central areas of both lung fields.

The patient was given oxygen through a positive pressure oxygen mask, and administration of erythromycin, dihydrostreptomycin and chloromycetin, $2 \mathrm{Gm}$. each day, were started. Hydrocortisone, $100 \mathrm{mg}$. every 12 hours, was injected intravenously, and prednisone, $100 \mathrm{mg}$. daily, was given by mouth. A summary of the patient's course is depicted in Figure 28.

Over the first four days in the hospital the patient showed moderate improvement. Oxyhemoglobin saturation rose to 93.9 per cent with use of the IPPB mask. Expiratory difficulties appeared relieved with alternating aerosols of Alevaire ${ }^{\circledR}$ and epinephrine, and temperature fell to below $39^{\circ} \mathrm{C}$. Nevertheless, signs of consolidation persisted, and she remained cyanotic and tachypneic when oxygen therapy was discontinued.

On the fifth hospital day the patient developed high tracheal obstruction which required tracheotomy and vigorous suctioning. Following this episode her condition worsened rapidly. There were numerous episodes of transient obstruction of various lobes by thick purulent mucus, and her temperature rose to 40 to $41^{\circ} \mathrm{C}$. A marked respiratory acidosis developed with the arterial $\mathrm{pCO}_{2}$ rising to $78 \mathrm{~mm}$. $\mathrm{Hg}$. The administration of acetazolamide, $1.0 \mathrm{Gm}$. daily, was associated with the return 


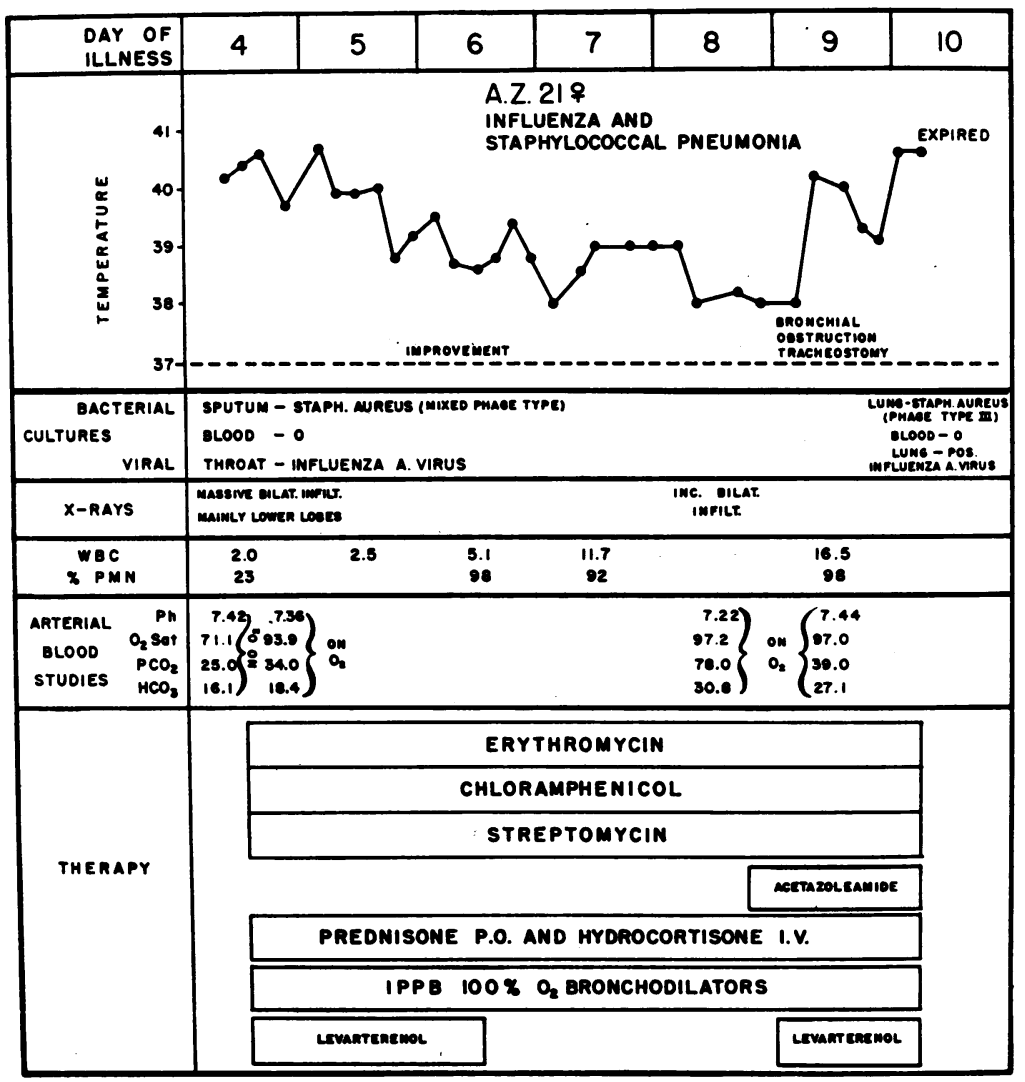

Fig. 28. Course of Illness in Patient A. Z.

of arterial blood $\mathrm{pCO}_{2}$ and $\mathrm{pH}$ to normal, but there was no improvement in the patient's clinical course. The onset of bloody diarrhea was associated with the recovery of hemolytic Staphylococcus aureus from stool cultures. On the sixth hospital day blood pressure fell to shock levels and the patient died.

Findings at autopsy (Autopsy No. 17315). Autopsy was limited to the removal of sections of organs through an abdominal incision. The lungs were obviously heavy and the lower lobes were nodular and firm. On section the parenchyma was diffusely hemorrhagic and airless, and small abscesses containing soft, yellow, purulent material were found in all lobes.

Microscopic examination revealed widespread ulceration of the bronchial mucosa together with extensive alveolar edema and hemorrhage. Many of the alveoli and alveolar ducts were covered with a thick hyaline membrane. Interstitial tissues were edematous and contained numerous polymorphonuclear leukocytes. As illustrated in Figure 10, the abscesses showed central necrosis and contained many colonies of cocci. Microscopic sections of the heart were not remarkable.

Quantitative bacterial cultures of the right upper and left lower lobes demonstrated a pure growth of hemolytic Staphylococcus aureus in concentrations of $5 \times 10^{8}$ microorganisms per $\mathrm{Gm}$. Bacteriophage typing revealed that these microorganisms were of phage type III (53 VA 4). This strain was resistant to more than $50 \mu \mathrm{g}$. of all antimicrobials except novobiocin. Influenza $A$ virus of the Asian strain was demonstrated in a concentration of $10^{2} \mathrm{EID}_{30}$ per $\mathrm{Gm}$. in lung tissue.

Comment. This young patient developed a rapidly fatal bilateral pneumonia. Both staphylococci and influenza virus were isolated from the sputum and the lungs at autopsy. During her hospitalization of six days, a drug-sensitive staphylococcus was replaced by a staphylococcus of different phage type which was insensitive to all antimicrobial agents used in treatment. It seemed probable that this microorganism entered the respiratory tract via tracheostomy tube during the last 36 hours of life.

3. R. C., NYH 653327. A 31 year old white woman was admitted on Oct. 23, 1957, with fever, cough and respiratory distress. The patient had known rheumatic heart disease and had undergone a mitral commissurotomy four and one-half years prior to admission. In recent months she had noted increasing fatigue and exertional dyspnea. Four days prior to admission the patient de- 
veloped an illness characterized by chills, fever and photophobia. Two days prior to admission she noted increasing cough, chills, fever and increasing dyspnea.

Physical examination disclosed an acutely and chronically ill cyanotic woman with moderate dyspnea. The temperature was $40.0^{\circ} \mathrm{C}$., respirations 28 per minute, heart rate 130 beats per minute, and blood pressure $98 / 65$ $\mathrm{mm}$. Hg. The neck veins were moderately distended. Examination of the chest revealed bilateral moist inspiratory rales over both lower lung fields. Sticky inspiratory rales and bronchial breath sounds were detected over the right middle lobe. The expiratory phase of respiration was moderately prolonged. The heart was moderately enlarged, and loud systolic and diastolic murmurs were heard at the apex. The liver was enlarged to $5 \mathrm{~cm}$. below the right costal margin and was tender. No peripheral edema was present.

Pertinent laboratory studies revealed a white blood cell count of 10,200 cells per cu. mm. with 67 per cent mature polymorphonuclear cells, 20 per cent band forms, and 2 per cent metamyelocytes. The sedimentation rate was $24 \mathrm{~mm}$. per hour. Electrocardiograms showed sinus tachycardia and evidence of right ventricular hypertrophy and "digitalis effect." The venous pressure was $150 \mathrm{~mm}$. saline at the level of the right auricle.

Sputum cultures yielded many colonies of hemolytic Staphylococcus aureus and pneumococci. The staphylococcus isolated was sensitive to the tetracyclines, chloramphenicol and erythromycin but was resistant to 3.25 units of penicillin. Chest roentgenography revealed diffuse, patchy densities radiating from the hilar areas bilaterally.

It was believed that the patient had chronic congestive heart failure and combined influenza virus and bacterial pneumonia. Treatment was initiated with digitoxin, mercurial diuretics and oxygen via the IPPB mask. Erythromycin and chloramphenicol, $2 \mathrm{Gm}$. daily, were given by mouth.

On this program the venous pressure returned to normal, but pulmonary signs failed to improve. Prednisone, $60 \mathrm{mg}$. daily, was started at this time. Dramatic improvement followed the initiation of steroid therapy. One week later prednisone was slowly withdrawn only to be followed by the return of fever, fatigue and dyspnea. Chest roentgenograms showed some clearing, but a diffuse reticular infiltrate remained. Prednisone was reinstituted and again there was rapid improvement and defervesence. Attempts were again made to withdraw the steroids, but again the patient's symptoms and fever returned and prednisone was therefore continued. The patient pursued a gradual downhill course characterized by fever, anemia and increasing heart failure, and she expired on the forty-ninth hospital day.

Study of paired serums obtained on the sixth and thirty-eighth day of illness showed an eightfold rise in influenza A complement fixing antibody.

Findings at autopsy (Autopsy No. 17357). The principal autopsy findings were confined to the heart and lungs. The heart weighed $380 \mathrm{Gm}$. and the myocardium was remarkably flabby. The mitral valve orifice was narrowed to a slit-like opening, and the mitral valve leaflets were thickened by fibrous tissue and focal calcification. The chordae tendineae were thickened and shortened. The walls of the coronary arteries were thin and their lumina patent. Microscopically there was an extensive infiltration of polymorphonuclear leukocytes associated with focal necrosis of myofibers throughout the heart. Aschoff bodies were not present. The blood vessels throughout the heart appeared normal.

The lungs together weighed $1,280 \mathrm{Gm}$. and the middle and lower lobes of the right lung were dark red and firm. Sections of the lung revealed marked passive hyperemia with extensive hemosiderin deposits within many mononuclear cells together with much alveolar hemorrhage and edema of recent origin. In some areas there was interstitial fibrosis and fibrosis of alveolar walls. Many small arteries, arterioles and capillaries in the right middle and lower lobes were necrotic and these areas were infiltrated with polymorphonuclear leukocytes. Cultures of lung tissue revealed a few colonies of coagulase positive staphylococci, Candida albicans, and E. coli. Influenza virus could not be obtained by inoculation of lung suspensions into embryonated eggs.

Comment. This patient with severe rheumatic heart disease developed influenza which was followed by bacterial pneumonia and congestive heart failure. Although there was an initial improvement, the subsequent course was one of fever, increasing congestive failure and anemia.

Autopsy was performed 53 days after the onset of her illness. A necrotizing myocarditis and pulmonary arteritis and arteriolitis were superimposed on chronic rheumatic deformities of the mitral valve. Influenza virus could not be recovered from the lung tissues.

This picture was strikingly different from that noted in other patients in this series. The prolonged course characterized by cardiac failure and anemia and the failure to demonstrate the influenza virus or the usual pulmonary changes associated with influenza suggest that the arteriolitis and myocarditis were perhaps of non-influenzal etiology.

4. B. $P$., NYH 73753. A 61 year old woman was admitted on Jan. 26, 1958, because of hemoptysis and dyspnea. The patient had been in good health until three days prior to admission when she noted the onset of fever, sore throat and shaking chills, followed in the next 24 hours by headache, nonproductive cough and generalized myalgia and arthralgia. She improved transiently but on the day of admission developed wheezing and respiratory distress, and her cough became productive of bloody sputum.

Physical examination revealed an acutely ill, cyanotic woman in marked respiratory distress. The admission 
temperature was $40.4^{\circ} \mathrm{C}$., the heart rate 122 beats per minute, respirations 60 per minute, and blood pressure $100 / 60 \mathrm{~mm}$. Hg. There was no venous distention. Examination of the chest revealed dullness to percussion over the left lower thorax posteriorly. Tubular breath sounds were heard in the area of dullness. Throughout the rest of the lung fields breath sounds were harsh, and grating expiratory rales and rhonchi were present. Examination of the heart revealed a sinus tachycardia and an accentuated pulmonic second sound. Physical examination was otherwise within normal limits.

Marked leukopenia was revealed by laboratory studies. The total leukocyte count was 1,400 cells per cu. $\mathrm{mm}$. with 86 per cent lymphocytes and 14 per cent polymorphonuclear cells. Hemoglobin and hematocrit determinations and a platelet count were normal. Granulocytic maturation arrest and a moderate increase in eosinophiles were evident in a bone marrow aspirate. A venous pressure determination and electrocardiogram were normal. The venous carbon dioxide combining power was $16 \mathrm{mM}$ per L.

Myriads of gram-positive cocci, red blood cells and leukocytes were seen in Gram stained smears of the sputum. Cultures yielded a pure growth of hemolytic Staphylococcus aureus (bacteriophage type I) which was sensitive to all antimicrobials tested. Blood cultures were sterile. A chest roentgenogram obtained on admission showed a dense left lower lobe infiltrate and a bilateral diffuse increase in hilar markings (Figure 29). Influenza virus (Asian strain) was recovered from the admission throat washing.

Antimicrobial therapy was initiated with chloramphenicol, $2 \mathrm{Gm}$. per day; streptomycin, $1 \mathrm{Gm}$. per day; and procaine penicillin, 2.4 million units per day. Oxygen

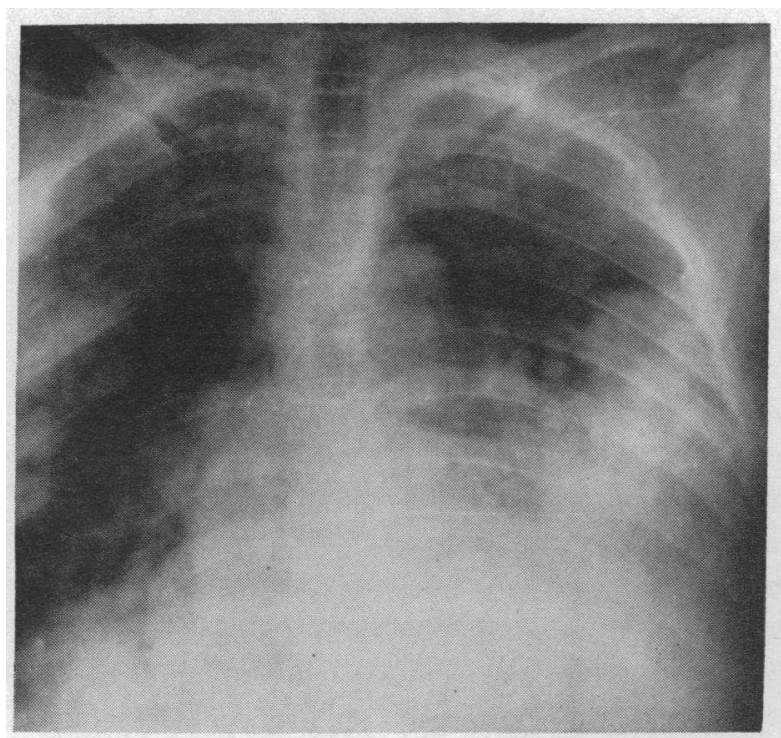

Fig. 29. Admission Chest Roentgenogram on Patient B. P., a 61 Year Old Woman with Concomitant Influenza Virus and Staphylococcal Pneumonia was administered via the IPPB mask. Shortly after admission, blood pressure fell to $70 / 40 \mathrm{~mm}$. $\mathrm{Hg}$ and intravenous norepinephrine was started. Hydrocortisone, 100 mg., was given intravenously. Despite this therapy, illness progressed. Twelve hours after admission arterial blood gas studies without administration of supplemental oxygen disclosed an oxyhemoglobin saturation of 70.5 per cent and carbon dioxide tension of $27 \mathrm{~mm}$. Hg. The serum bicarbonate concentration was $9.63 \mathrm{mM}$ per L., and the arterial blood $\mathrm{pH}$ was 7.18 units.

Penicillin dosage was increased to 40 million units intravenously per 24 hours given as a continuous slow infusion, but respiratory distress progressed relentlessly, and the patient died 20 hours after admission.

Findings at autopsy (Autopsy No. 17449). The mucosal surfaces of the larynx, trachea and major bronchi were hyperemic and granular and the lumina contained much bloody fluid. The lungs were heavy and hemorrhagic and together weighed $1,920 \mathrm{Gm}$. The basilar portions of the upper lobes, the entire right middle lobe and both lower lobes were noncrepitant, firm and dark red.

In the upper lobes, the alveolar capillaries were markedly hyperemic. Many of the alveolar lumina were filled with a pink, granular precipitate, and in some areas alveolar hemorrhage was prominent. The ciliated epithelium of many of the small bronchi appeared normal, but their lumina contained cellular debris, neutrophilic leukocytes, red blood cells, edema fluid and many grampositive cocci. In one area the inflammatory process was associated with necrosis of alveolar walls. All of these changes were much more marked in the lower lobes, and hemorrhage, edema and abscess formation were widespread. Huge numbers of gram-positive cocci were readily identified within the lung parenchyma. Careful search failed to reveal hyaline membranes in any lobes of the lungs. The remainder of the organs, including the brain, were grossly and microscopically unremarkable.

A pure growth of hemolytic Staphylococcus aureus was cultured in high titer from all lobes. Staphylococci in concentrations of $4 \times 10^{4}$ microorganisms per $\mathrm{Gm}$. were grown from the left upper lobe. The right lower lobe and left lower lobe contained $4 \times 10^{8}$ viable staphylocci per Gm. The staphylococci isolated were of the same phage type and antimicrobial sensitivity as the strain originally isolated from the sputum. The Asian strain of influenza A virus was recovered from the lungs in concentrations of $10^{2.7} \mathrm{EID}_{50}$ per $\mathrm{Gm}$.

Comment. This patient had a typical influenzal illness followed in three days by a fulminating pneumonia which resulted in death. Both influenza virus and hemolytic Staphylococcus aureus were isolated from lung tissue post mortem. Leukopenia and granulocytopenia accompanied the illness. Despite the susceptibility of the staphylococcus to the antimicrobials administered, the patient died shortly after admission to the hospital. 


\section{RECAPITULATION}

The present paper reports observations on 33 patients with proven influenza A infection who developed pulmonary complications during their illness. On the basis of detailed clinical and laboratory study, four clinical syndromes were recognized :

1. Influenza with physical signs of lung involvement but without roentgenographically detectable pulmonary infiltrates.

2. Focal bacterial pneumonia following influenza.

3. Influenza associated with a diffuse pulmonary process produced by influenza virus infection alone.

4. Influenza associated with both focal and diffuse pulmonary signs resulting from concomitant bacterial and influenza virus infection.

Influenza with physical signs of lung involvement without roentgenographic pulmonary infiltrates

Three patients developed scattered rales and wheezes over the lower lung fields without evidence of bacterial infection or roentgenographic infiltrates. Each of these patients had underlying disease producing pulmonary hypertension. These patients recovered without antimicrobial therapy in a manner generally similar to that seen in uncomplicated influenza.

Transient lower respiratory tract signs without changes in chest X-ray films have been reported to occur in occasional patients with influenza and have been considered to represent bronchial and bronchiolar involvement $(17,18)$. It seems probable that the relative infrequency of this pulmonary syndrome in our series was the result of an admission policy in force during the epidemic which suggested the hospitalization of influenza patients only when pulmonary signs were accompanied by roentgenographic pulmonary infiltrates.

Focal bacterial pneumonia following infuenza contrasted with the syndrome of diffuse primary influenza virus pneumonia

Fifteen of the 33 patients had definite evidence of bacterial pneumonia arising sometime after the onset of influenza. Six patients manifested a severe, diffuse pulmonary syndrome without ap- parent bacterial infection which appeared to result from influenza virus infection per se. These two syndromes differed sharply from one another and could be separated clinically with increasing certainty as the epidemic proceeded. These differences deserve enumeration.

1. The host setting in which disease arose was different in the two syndromes. Focal bacterial pneumonia often arose in previously healthy individuals. In this group the numbers of male and female patients were approximately equal.

In contrast, all six of the patients with the diffuse abacterial pulmonary syndrome had underlying heart disease. Rheumatic heart disease with mitral valve involvement was present in four. Five of the six patients were males.

2. The progression of the illnesses differed. Patients who presented with what was subsequently proved to be bacterial pneumonia usually experienced a longer interval between the onset of influenza symptoms and hospitalization which averaged 3.8 days. Ten of the 15 patients with bacterial pneumonia had noted a period of relative freedom from symptoms following influenza before symptoms suggesting bacterial infection became apparent. Chills, fever, cough productive of purulent or bloody sputum and pleural pain were the principal complaints upon admission.

In contrast, all patients presenting with diffuse influenza virus pneumonia had had illness of short duration. In these patients typical influenza symptoms were followed in less than 24 hours by progressive dyspnea. Profound respiratory distress was the universal complaint upon admission. Pleural pain was not present.

3. Findings on physical examination were different in the two groups. The majority of patients with focal bacterial pneumonia had high fever, grunting respirations and typical signs of focal consolidation over one or more lobes. $\mathrm{Cy}$ anosis or severe respiratory distress was rare.

In contrast, patients with diffuse, abacterial pneumonia had no signs of local consolidation. Chest findings were bilateral and diffuse, and were characterized by difficulties in air exchange, rales, inspiratory and expiratory wheezes and rhonchi. Cyanosis was uniformly present and respiratory distress was extreme:

4. Certain laboratory studies aided in differentiating these two syndromes. a) Many polymor- 
phonuclear leukocytes and masses of bacteria were observed in smears of sputum obtained from patients with bacterial pneumonia. Pathogens known to produce pneumonia were readily cultured from the sputum. In contrast, sputum smears obtained from patients with influenza virus' pneumonia revealed only sparse bacteria, and sputum cultures consistently failed to yield significant pathogenic microorganisms.

b) Differences were apparent in the incidence of recoveries of influenza virus from throat washings. No influenza virus was obtained from 13 patients with bacterial pneumonia in whom virus isolation was attempted. In contrast, influenza virus was recovered from three of four patients with primary influenza virus pneumonia from whom throat washings were obtained.

c) Roentgenographic findings differed in patients with secondary bacterial and primary influenza virus pneumonia. Chest X-rays on patients with bacterial pneumonia commonly showed typical focal infiltrates confined to one or more lobes. In patients with influenza virus pneumonia, a diffuse, fanning, bilateral, perihilar infiltrate, indistinguishable from the roentgenographic picture observed in cardiac pulmonary edema was a characteristic finding.

5. The course of illness was different in patients with secondary bacterial and primary influenza virus pneumonia. Patients with focal bacterial pneumonias responded promptly to antimicrobial therapy in a manner similar to that ordinarily seen in primary bacterial pneumonias. The mortality was low in this group. One of 15 patients died with what appeared to be a complication unassociated with her influenza.

In contrast, patients with diffuse abacterial pneumonia failed to respond to the administration of large doses of antimicrobial drugs. Hypoxia, respiratory distress and respiratory and metabolic acidosis progressed relentlessly despite therapy. Five of the six patients with this syndrome died.

\section{Combined influenza virus and bacterial pneumonia}

Nine patients with pulmonary infiltrates had an illness which was characterized by certain features of both focal bacterial pneumonia and diffuse influenza virus pneumonia. In these patients the duration of illness prior to hospitalization was variable. Respiratory distress was a universal complaint on admission. Both focal and diffuse findings were usually present on physical and roentgenologic examination. Large numbers of pneumococci, staphylococci or Hemophilus influenzae were isolated from the sputum, and influenza virus was simultaneously present in seven of nine throat washings obtained. This syndrome, in common with primary influenza virus pneumonia, was associated with a significant mortality. Four of the nine patients died during the course of their illness. Findings during the acute illness in the two patients examined post mortem were similar to those noted in primary influenza virus pneumonia, but in addition, histologic and cultural evidence of an extensive necrotizing staphylococcal pneumonia was present.

\section{Other laboratory features of pneumonia associated with influenza}

Certain laboratory studies did not aid in differentiating the pulmonary syndromes observed. In all syndromes patients demonstrated a leukocytosis with an increase in absolute numbers of granulocyte forms. Erythrocyte sedimentation rates were usually normal in patients with diffuse influenza virus pneumonia and high in patients with associated bacterial infection, but too few patients were studied to assess the constancy of this observation.

No evidence of renal or hemopoietic damage or defects in blood clotting mechanisms accompanied influenza. Tests of hepatic function were generally within normal limits during the acute illness except for serum glutamic oxaloacetic transaminase determinations. Transaminase levels were elevated in the majority of patients studied, and the degree of elevation of serum transaminase levels appeared to parallel the severity of the illness. In the absence of other changes suggestive of hepatic or myocardial damage, the significance of this finding remains unclear. Viremia was not demonstrated during the course of influenza.

\section{Consideration of primary influenza virus pneu- monia as a specific disease entity}

As the belief evolved that pure influenza virus pneumonia represented a definite entity, two questions arose in considering the clinical syndrome 
manifested by the six patients described in the present report.

1. Could bacterial infection have been missed in these patients who received large amounts of antimicrobials? This has seemed unlikely. First, bacteria were easily cultured from sputum samples obtained from patients simultaneously admitted with other pulmonary syndromes, while repeated cultures did not yield significant bacterial pathogens from the sputum of these six patients. Secondly, three of five patients with the diffuse pulmonary syndrome died within 48 hours after institution of therapy without bacteriologic or histologic evidence of infection. Experimental evidence indicates that antimicrobial therapy rarely eradicates microorganisms residing in tissues within this time period. Furthermore, microorganisms were cultured in high concentrations and were readily seen on histologic sections from the lungs of influenza patients with bacterial pneumonias who died after comparable time periods on similar therapy. Thus it seems unlikely that antibiotics induced bacterial sterility in lungs during such short periods of drug administration.

It is conceivable that antimicrobial treatment could eradicate pneumococci because of their tendency to autolyse rapidly when killed. Nevertheless, the diffuse pulmonary syndrome observed, the lack of response to antimicrobials, the presence of distinctive and unusual anatomic findings, and the absence of the pulmonary histologic changes usually seen in pneumococcal pneumonia suggest that this was a most unlikely possibility. Lastly, high concentrations of influenza virus were demonstrated in the lungs of these patients. In three of the four patients, virus concentrations were 20 to 2,000 times those found in patients with influenza who died with obvious bacterial infections.

2. Was it possible that this diffuse syndrome represented acute left heart failure? All of the patients with diffuse abacterial pneumonia had antecedent heart disease, and chest X-ray films were compatible with acute pulmonary edema. There was, however, considerable evidence to indicate that the process observed was not congestive heart failure.

First, four of the six patients had significant pulmonary hypertension secondary to mitral valvular lesions. It might be expected that any additional stress placed on the heart would result in rapid right heart failure. Nevertheless, signs of right heart failure were generally absent, and blood volumes and venous pressures were commonly normal. Secondly, there were no physical or electrocardiographic signs to suggest the presence of myocarditis. Third, the institution of vigorous therapeutic measures for acute congestive heart failure produced no significant change in the pulmonary picture. Lastly, the findings at autopsy were not those of heart failure and indicated that a diffuse pulmonary infection was present.

We are thus led to the conclusion that influenza virus infection in the absence of bacterial complications produced a characteristic, severe and usually fatal pneumonic syndrome in certain patients with underlying heart disease.

\section{DISCUSSION}

At the outset of the recent pandemic there was little evidence that influenza virus per se could cause fatal pneumonia when unattended by bacterial pathogens. The first documented abacterial influenza virus pneumonia, described in 1945 by Finland, Barnes and Samper (19), was associated with an interpandemic infection. The following year a second case report appeared from the same group of investigators (15). In both cases the minimal acceptable criteria for primary influenza virus pneumonia were met; virus was recovered from lung tissue and bacterial pathogens could not be demonstrated (see Table XV). Except for an undocumented reference to another case of apparent abacterial influenza virus pneumonia in 1948 (20), other instances of fatal primary influenza virus pneumonia were not described before the recent pandemic.

The present investigation has documented six cases of influenza virus pneumonia in which bacterial pathogens could not be incriminated. Five of these patients died. Other investigations of the 1957-58 pandemic also present evidence that fatal abacterial influenza may occur. Four of eight fatal pneumonias reported by Giles and Shuttleworth were bacteriologically sterile (21). Details of these cases were not published. In a large prospective study of fatal influenza in the Netherlands, 22 instances of bacterially sterile lungs were reported in 103 patients in whom pulmonary in- 
fluenza virus was demonstrated post mortem (22). Three additional cases have been reported recently in which influenza virus was recovered from bacteriologically sterile lungs $(23,24)$. Thus at the present writing, 31 such cases (excluding the present six) have been reported (Table XV). Although detailed presentations of the clinical manifestations of illness have been few, our experience, supported by the reports cited above, indicate that influenza virus infection per se can be a cause of pneumonia and death in man.

Although the view has been widely held that influenza virus infection per se does not produce fatal disease, it has long been recognized that influenza epidemics are closely associated with an increased incidence of bacterial pneumonia $(25,26)$. In the present study, 24 of 33 patients had evidence of superimposed or subsequent bacterial pulmonary infection. In the 1918-19 pandemic, pathogenic bacteria were almost invariably isolated from the lungs of fatal cases of influenza (27-29). Since the initial recognition of influenza virus in 1933 (3) the isolation of both influenza virus and bacteria from the lungs of fatal cases has been repeatedly documented $(17,18,30)$. In the majority of such fatal pneumonias, the associated bacterial pathogen has been Staphylococcus aureus $(17,18,30$ and 31). The frequent isolation of staphylococci and influenza virus from the lungs in fatal influenza (Table XV) has focused attention on the bacterial problem, especially as antibiotic-resistant staphylococci have become increasingly prevalent.

In the absence of firm evidence in the past that influenza virus alone might induce fatal pneumonia, the pathogenic contribution of the virus in combined viral-bacterial infections has often been considered minor. The fact that effective antibacterial drugs were available in the recent pandemic has allowed clearer differentiation of the relative importance of the virus in such combined infections. The present investigation, in which bacteria generally sensitive to antimicrobials were encountered in patients with concomitant viral and bacterial pneumonia, has allowed some clarification of the role of the influenza virus in such combined infections.

Three facts suggest that the severity of the influenza virus infection per se may be important in determining the outcome of combined influenza and bacterial pneumonia:
First, it was apparent from the present investigation that patients died from influenza virus infection alone.

Secondly, the diffuse nature of the pulmonary disease observed and the severe respiratory diffculties associated with combined viral-bacterial pneumonia in certain patients were not characteristic of bacterial pneumonia but more closely resembled the signs and symptoms observed in patients with pure influenza virus pneumonia.

Third, certain patients with combined infection produced by influenza virus and antibiotic-sensitive bacteria failed to exhibit an appropriate response to antimicrobial agents. Deaths in some of these patients were clearly not related to a failure of antibacterial therapy but seemed to result from the unmitigated effects of the viral component of the combined infection. In those in this group who survived, the recovery phase was protracted, regardless of the bacterial pathogen involved. This slow response stood in sharp contrast to the response of patients who developed secondary pneumonia following the earlier onset of influenza.

On the basis of this experience the present authors are led to believe that the virus infection does more than merely reduce host resistance to bacterial invasion. It seems probable that the influenza virus per se plays an important role in deaths observed in such combined viral-bacterial pneumonias.

The deaths observed in two patients with combined influenza virus and staphylococcal infections were reminiscent of the fatalities attributed to staphylococcal pneumonia in 1918-19 by Chickering and Park (32). The syndrome described by these authors has always been puzzling to students of staphylococcal infection because of the diffuse pulmonary involvement and the lack of pleural pain or empyema so common in most staphylococcal pulmonary infections (33). Our recent experience suggests that the clinical manifestations observed by Chickering and Park may have been determined by influenza virus infection acting in concert with necrotizing bacterial disease rather than staphylococcal infection alone.

The picture of the staphylococcus as an increasingly important co-invader in influenza must be viewed with caution. In the present investigation of living patients, the high incidence of pneumococcal pneumonia contrasts with the low inci- 
dence of pneumococci reported in autopsy material from fatal cases of influenza (22). It should be remembered that the antimicrobial treatment of pneumococcal or streptococcal infections is vastly more effective than the treatment of staphylococcal disease. Antimicrobial therapy may thus, in part, select the bacterial agent (staphylococcus) which will result in an influenza fatality, and a spurious etiologic relationship may be inferred by study of postmortem materials alone.

The present study emphasizes the importance of underlying disease in the pathogenesis of pulmonary complications of influenza. Twenty-one of the 30 patients with serious pulmonary complications, including nine of the 11 who died, had underlying illness or were pregnant. This correla- tion was even more striking in patients with diffuse virus pneumonia with or without pre-existing disease. In this group, 13 of the $15 \mathrm{pa}-$ tients had pre-existing disease. This experience is in general accord with the observations of others reported during the last two decades. Table XV summarizes published reports of fatal cases of influenza in which virus with or without associated bacterial pathogens was demonstrated in the lung. In 14 of these cases adequate data were available to determine whether or not underlying disease was present before the onset of influenza. Six of these 14 patients clearly had preceding disease. In two other reported cases the data provided suggest the possibility of antecedent disease. Of the remaining six patients without manifest antecedent

TABLE XV

Fatal cases of influenza in which virus was demonstrated in the lung

\begin{tabular}{|c|c|c|c|c|c|c|c|c|c|c|}
\hline \multirow[b]{2}{*}{ Reference } & \multirow[b]{2}{*}{ Date } & \multirow[b]{2}{*}{ Patient } & \multirow[b]{2}{*}{ Age } & \multirow[b]{2}{*}{ Sex } & \multirow{2}{*}{$\begin{array}{l}\text { Under- } \\
\text { lying } \\
\text { disease* }\end{array}$} & \multicolumn{2}{|c|}{ Bacterial culture $\dagger$} & \multicolumn{2}{|c|}{$\begin{array}{c}\begin{array}{c}\text { Isolation of } \\
\text { influenza virus }\end{array} \\
\end{array}$} & \multirow[b]{2}{*}{ Comment } \\
\hline & & & & & & Sputum & Lung & $\begin{array}{l}\text { Throat } \\
\text { wash. }\end{array}$ & Lung & \\
\hline $\begin{array}{l}\text { 1. Scadding } \\
\text { (17) }\end{array}$ & 1937 & к. 0. & 16 & F & 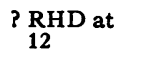 & NR & Staph. & NR & A & \\
\hline $\begin{array}{l}\text { 2. Stuart-Harris, } \\
\text { Andrewwes and } \\
\text { Smith (18) }\end{array}$ & 1938 & $\begin{array}{l}\text { A. L. E. } \\
\text { O. A.K. } \\
\text { W. A. N. }\end{array}$ & $\begin{array}{l}? \\
? \\
?\end{array}$ & $\begin{array}{l}? \\
? \\
?\end{array}$ & $\begin{array}{l}\text { No details } \\
\text { No details } \\
\text { No details }\end{array}$ & $\begin{array}{l}\text { NR } \\
\text { NR } \\
\text { NR }\end{array}$ & $\begin{array}{l}\text { Staph. } \\
\text { Staph. } \\
\text { Staph. }\end{array}$ & $\begin{array}{l}\text { ND } \\
\text { ND } \\
\text { ND }\end{array}$ & $\begin{array}{l}\text { Af } \\
\text { Af } \\
\text { Af }\end{array}$ & \\
\hline $\begin{array}{l}\text { 3. Stokes and } \\
\text { Wolman (39) }\end{array}$ & 1940 & & 20 & F & $\begin{array}{l}\text { Furuncu- } \\
\text { losis }\end{array}$ & NR & Staph. & NR & A & \\
\hline 4. Himmelweit & 1943 & & 55 & $\mathbf{M}$ & None & NR & Staph. & NR & B & \\
\hline \multirow{3}{*}{$\begin{array}{l}\text { 5. Finland, } \\
\text { Barnes and } \\
\text { Samper (19) }\end{array}$} & \multirow[t]{3}{*}{1945} & $A-1$ & 18 & $\mathbf{F}$ & None & $\beta$ strep. staph. & $\beta$ strep. staph. & NR & $\mathbf{A}$ & \\
\hline & & $A-2$ & 39 & $\mathbf{M}$ & CAD & $\mathbf{0}$ & Alpha strep. & NR & A & $\begin{array}{l}\text { This organism is an } \\
\text { unlikely pathogen }\end{array}$ \\
\hline & & $A-3$ & 61 & $\mathbf{M}$ & ASCVD & Pneumo. I & Pneumo. I & NR & A & \\
\hline \multirow{2}{*}{$\begin{array}{l}\text { 6. Parker, } \\
\text { Jolliffe, } \\
\text { Barnes and } \\
\text { Finland (15) }\end{array}$} & \multirow[t]{2}{*}{1946} & 1 & 18 & F & None & NR & Staph. & ND & A & \\
\hline & & 2 & 34 & F & $\begin{array}{l}\text { Antecedent } \\
\text { cough, } \\
\text { fatigue, } \\
\text { coincident } \\
\text { myocarditis }\end{array}$ & $\begin{array}{l}\text { N. catarrhalis } \\
\text { staph. } \\
\text { (few) }\end{array}$ & 0 & ND & A & Abacterial \\
\hline $\begin{array}{l}\text { 7. Burnet, } \\
\text { Stone and } \\
\text { Anderson (40) }\end{array}$ & 1946 & 3 & 47 & F & No details & ND & Staph. & ND & B & $\begin{array}{l}\text { (Reisolated) } \\
\text { bronchial washings }\end{array}$ \\
\hline \multirow{4}{*}{$\begin{array}{l}\text { 8. Maxwell, } \\
\text { Ward and } \\
\text { Van Metre } \\
\text { (20) }\end{array}$} & \multirow[t]{4}{*}{1949} & P47A1 & \multirow{5}{*}{$\begin{array}{l}14 \\
\text { mo. } \\
7 \\
\text { mo. }\end{array}$} & $\mathbf{M}$ & Varicella & NR & ND & NR & A & \\
\hline & & P47A2 & & \multirow{4}{*}{$\mathbf{M}$} & Meningitis & NR & ND & NR & A & \\
\hline & & P46A1 & & & No details & NR & Pneumo. II & NR & A & \\
\hline & & P47B1 & & & No details & Pneumo. IX & $\mathbf{0}$ & NR & B & Possibly abacterial \\
\hline $\begin{array}{l}\text { 9. Stuart-Harris } \\
\text { and co-workers } \\
(26)\end{array}$ & 1949 & 4 cases & & & No details & NR & Staph.-4 & NR & $\mathbf{A}$ & \\
\hline $\begin{array}{l}\text { 10. Mulder and } \\
\text { Verdonk (41) }\end{array}$ & 1949 & $\mathbf{K}$ & 27 & $\mathbf{M}$ & None & $\begin{array}{l}\text { Staph. (lung } \\
\text { puncture) }\end{array}$ & Staph. & ND & Af & Tracheal isolation \\
\hline
\end{tabular}

* RHD, Rheumatic heart disease; MS, Mitral stenosis; CAD, Coronary artery disease; ASCVD, Arteriosclerotic heart disease.

† NR, Not reported; ND, Not done; Staph., hemolytic Staphylococcus aureus; Strep., Group A hemolytic streptococcus; pneumo., pneumoIdentification of virus only presumptive on basis of data published.

Note-Isolations of virus from 195 fatal cases (43) are not summarized here because the data in this report do not allow conclusions regarding individual cases nor is it stated how many isolations are from pulmonary tissue. 


\begin{tabular}{|c|c|c|c|c|c|c|c|c|c|c|}
\hline \multirow[b]{2}{*}{ Reference } & \multirow[b]{2}{*}{ Date } & \multirow[b]{2}{*}{ Patient } & \multirow[b]{2}{*}{ Age } & \multirow[b]{2}{*}{ Sex } & \multirow{2}{*}{$\begin{array}{l}\text { Under- } \\
\text { lying } \\
\text { disease* }\end{array}$} & \multicolumn{2}{|c|}{ Bacterial culture $†$} & \multicolumn{2}{|c|}{$\begin{array}{c}\text { Isolation of } \\
\text { influenza virus }\end{array}$} & \multirow[b]{2}{*}{ Comment } \\
\hline & & & & & & Sputum & Lung & $\begin{array}{l}\text { Throat } \\
\text { wash. }\end{array}$ & Lung & \\
\hline $\begin{array}{l}\text { 11. Evans and } \\
\text { Evans (42) }\end{array}$ & 1956 & 1 & 53 & $\mathbf{F}$ & No details & Staph. & NR & ND & $\mathbf{A}$ & $\begin{array}{l}\text { No data on viral } \\
\text { isolation }\end{array}$ \\
\hline $\begin{array}{l}\text { 12. Giles and } \\
\text { Shuttleworth } \\
\text { (21) }\end{array}$ & 1957 & 8 cases & & & No details & NR & $\begin{array}{l}\text { Staph. }-4 \\
0-4\end{array}$ & NR & $\underset{\text { (Asian) }}{\mathbf{A}}$ & Four abacterials \\
\hline $\begin{array}{l}\text { 13. Hers, } \\
\text { Goslings, } \\
\text { Masurel and } \\
\text { Mulder (22) }\end{array}$ & 1957 & 103 cases & & & See comment & & 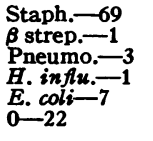 & & $\underset{\text { (Asian) }}{\mathbf{A}}$ & $\begin{array}{l}22 \text { abacterial. } \\
\text { Of } 10 \text { patients with } \\
\text { RHD and MS, nine } \\
\text { were abacterial }\end{array}$ \\
\hline \multirow{2}{*}{$\begin{array}{l}\text { 14. Perrier, } \\
\text { Hausser and } \\
\text { Paccaud (23) }\end{array}$} & \multirow[t]{2}{*}{1957} & L. T. & 19 & $\mathbf{M}$ & None & NR & $\mathbf{0}$ & NR & \multirow{2}{*}{$\begin{array}{c}\mathbf{A} \\
\text { (Asian) } \\
\mathbf{A} \\
\text { (Asian) }\end{array}$} & \multirow[t]{2}{*}{ Two abacterial } \\
\hline & & H. B. & 57 & $\mathbf{F}$ & $\begin{array}{l}\text { None } \\
\text { (obesity) }\end{array}$ & NR & $\mathbf{0}$ & NR & & \\
\hline $\begin{array}{l}\text { 15. Rock, } \\
\text { Braude and } \\
\text { Moran (24) }\end{array}$ & 1958 & & 38 & $\mathbf{F}$ & RHD, MS & $\begin{array}{l}\text { Strep. viridans, } \\
N . \text { catarrhalis }\end{array}$ & $\mathbf{0}$ & ND & $\underset{\text { (Asian) }}{A}$ & $\begin{array}{l}\text { Virus reisolated, } \\
\text { abacterial }\end{array}$ \\
\hline \multirow[t]{7}{*}{$\begin{array}{l}\text { 16. Present } \\
\text { report }\end{array}$} & \multirow[t]{7}{*}{1958} & G. H. & 49 & $\mathbf{M}$ & RHD & $\begin{array}{l}\text { Rare pneumo., } \\
\text { normal flora }\end{array}$ & $\mathbf{0}$ & ND & $\underset{\left(\begin{array}{c}\text { Asian) } \\
\left(10^{6} \cdot 3\right)\end{array}\right.}{A}$ & $\begin{array}{l}\text { First four cases } \\
\text { abacterial }\end{array}$ \\
\hline & & C. P. & 47 & $\mathbf{M}$ & RHD & $\begin{array}{l}\text { Normal flora, } \\
\text { rare pneumo., } \\
\text { pseudomonas, } \\
\text { proteus }\end{array}$ & $\mathbf{0}$ & ND & 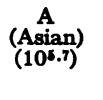 & $\begin{array}{l}\text { Virus reisolated } \\
\text { from lungs in five of } \\
\text { seven cases }\end{array}$ \\
\hline & & A. B. & 45 & $\mathbf{M}$ & RHD & $\begin{array}{l}\text { Normal flora, } \\
\text { few } B \text {. influ- } \\
\text { ensae, pneumo. }\end{array}$ & $\mathbf{0}$ & $\underset{\text { (Asian) }}{\mathbf{A}}$ & $\underset{(\mathbf{1 0 4})}{\mathrm{A}}$ & \\
\hline & & A. C. & 66 & $\mathbf{M}$ & ASCVD & Normal flora & $\mathbf{0}$ & $\underset{\text { (Asian) }}{\mathbf{A}}$ & $\underset{(\text { Asian) }}{\mathbf{A}}$ & \\
\hline & & F. R. & 53 & $\mathbf{M}$ & Myeloma & Pneumo. & 0 & $\underset{\text { (Asian) }}{\mathbf{A}}$ & $\begin{array}{c}\text { A } \\
(\text { Asian) } \\
\left(<10^{\circ}\right)\end{array}$ & \\
\hline & & A. Z. & 21 & $\mathbf{F}$ & None & Staph. & $\begin{array}{l}\text { Staph. } \\
5 \times 10^{8} / \mathrm{ml}\end{array}$ & $\underset{\text { (Asian) }}{\mathbf{A}}$ & $\begin{array}{c}\mathbf{A} \\
\left(\begin{array}{l}\text { (10:) } \\
\text { (Asian) }\end{array}\right.\end{array}$ & \\
\hline & & B. P. & 61 & $\mathbf{F}$ & None & Staph. & $\begin{array}{l}\text { Staph. } \\
4 \times 10^{8} / \mathrm{ml}\end{array}$ & $\underset{\text { (Asian) }}{\mathbf{A}}$ & 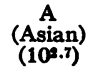 & \\
\hline
\end{tabular}

disease, four had both staphylococcal and influenza virus lung involvement. Thus only two of the 14 patients reported in adequate detail could be considered to be normal individuals who died solely of uncomplicated influenza virus infection.

The specific association of underlying cardiovascular disease with serious pulmonary complications of influenza was particularly striking in the present study (Table XVI). Fourteen or two-thirds of the 21 patients with an antecedent illness had cardiovascular disease; 10 of the 14 had rheumatic heart disease. If the patients with diffuse lung involvement (with or without bacterial infection) are considered as a separate group, the incidence of underlying cardiovascular disease is even more impressive. Eleven of 15 such patients had known underlying cardiac disease. In seven of these 11, rheumatic heart disease was present.
The impression that individuals with rheumatic heart disease manifest increased susceptibility to pneumonic involvement with influenza virus infection is supported by other observations reported from the pandemic of 1957-58. Rock, Braude and Moran have reported a patient with mitral stenosis who developed fatal abacterial influenza virus pneumonia (24). In the Netherlands study, nine of 10 cases with mitral stenosis had abacterial influenza virus pneumonia (22). Thirty-five of 46 fatal cases with clinical diagnoses of influenza reported by Giles and Shuttleworth had pre-existing disease. In seven of the 35 , rheumatic heart disease was present (21).

The prognostic import of underlying rheumatic heart disease was grim with any of the pneumonic syndromes associated with influenza observed in the present study (see Table XVI). The only 
death among patients with late bacterial pneumonia following influenza occurred in a rheumatic patient. Of three patients with rheumatic heart disease and concomitant bacterial and viral pneumonia, one died; of four with rheumatic heart disease and primary influenza virus pneumonia, three died. Thus five of 10 rheumatics who developed pneumonia in association with influenza failed to survive.

Thus, the present study suggests not only the importance of antecedent disease but specifically the importance of cardiovascular disease in the pathogenesis of influenza virus pneumonia. The fact that mitral stenosis was the most common cardiovascular defect suggests the probable importance of hemodynamic rather than general debilitating factors in the genesis of the syndrome. It seems probable that the pulmonary hypertension associated with mitral stenosis may play an important role in the pathogenesis of the hemorrhagic, edematous pneumonia induced by influenza virus.

Certain comparisons of the pandemics of 1918-19 and 1957-58 can be made on the basis of the present experience. The clinical picture of influenza in uncomplicated cases in 1957-58 $(5,6)$ was remarkably similar to that described in 1918-19 (34). The clinical syndrome of fulminating pneumonia as observed in the present series also closely resembles certain clinical descriptions of fulminant pneumonia in 1918-19 $(35,36)$.

There were, however, two important differences in the two pandemics: First, the fatality rate was high in 1918-19 and low in 1957-58 (37). Sec- ond, fatalities were disproportionately common in young adults in 1918-19. Deaths occurred principally in older age groups in 1957-58 (38).

At first glance, these facts suggest marked differences in the virulence of the viruses of the two pandemics. It appears more probable, however, that factors other than virus virulence, especially the use of antimicrobial drugs, reduced the frequency of severe disease in the recent pandemic. Virtually all well-studied influenza fatalities in 1918-19 were associated with bacterial infections of the lung. Although bacterial pneumonias produced significant mortality in 1957-58, five of 11 or almost 50 per cent of patients in the present study who died had a diffuse hemorrhagic pneumonia apparently produced solely by influenza virus infection. The previously cited studies of other investigators also indicate that influenza virus pneumonia without bacteria was an important cause of death in 1957-58. It is likely that control of many superimposed bacterial pneumonias with drug therapy operated to select such abacterial cases.

The premise that mortality is unrelated to intrinsic virus virulence receives further support from the observation that 80 per cent of the deaths observed in the present series occurred in patients with serious underlying disease. This high coincidence of influenza fatality and underlying disease was not observed in the large number of young adults who died in 1918-19. However, it is probable that the selective crowding of young people under war time conditions together with the lack of effective therapy for the bacterial complications

TABLE XVI

The association of underlying disease with pulmonary complications of influenza: The importance of antecedent cardiac disease

\begin{tabular}{|c|c|c|c|c|c|c|c|}
\hline \multirow[b]{2}{*}{ Disease syndrome } & \multirow[b]{2}{*}{$\begin{array}{l}\text { No. of } \\
\text { patients }\end{array}$} & \multicolumn{3}{|c|}{ Incidence of underlying disease* } & \multicolumn{3}{|c|}{ Deaths } \\
\hline & & $\begin{array}{l}\text { Total } \\
\text { no. } \\
\text { patients }\end{array}$ & $\begin{array}{l}\text { No. with } \\
\text { CV } \\
\text { disease }\end{array}$ & $\begin{array}{l}\text { No. } \\
\text { with } \\
\text { RHD }\end{array}$ & $\begin{array}{l}\text { Total } \\
\text { no } \\
\text { whodied }\end{array}$ & $\begin{array}{l}\text { No. with } \\
\text { underlying } \\
\text { disease }\end{array}$ & $\begin{array}{l}\text { No. with } \\
\text { RHD } \\
\text { who died }\end{array}$ \\
\hline $\begin{array}{l}\text { Influenza complicated by } \\
\text { bacterial pneumonia }\end{array}$ & 15 & $8 \dagger$ & 3 & 3 & 1 & 1 & 1 of 3 \\
\hline $\begin{array}{l}\text { Concomitant influenza virus } \\
\text { and bacterial pneumonia }\end{array}$ & 9 & $7 \dagger$ & 5 & 3 & 5 & 3 & 1 of 3 \\
\hline $\begin{array}{l}\text { Primary influenza virus } \\
\text { pneumonia }\end{array}$ & 6 & 6 & 6 & 4 & 5 & 5 & 3 of 4 \\
\hline Totals & 30 & 21 & 14 & 10 & 11 & 9 & 5 of 10 \\
\hline
\end{tabular}

* CV, cardiovascular disease; RHD, rheumatic heart disease.

$\dagger$ In one of this number the "disease" was pregnancy. 


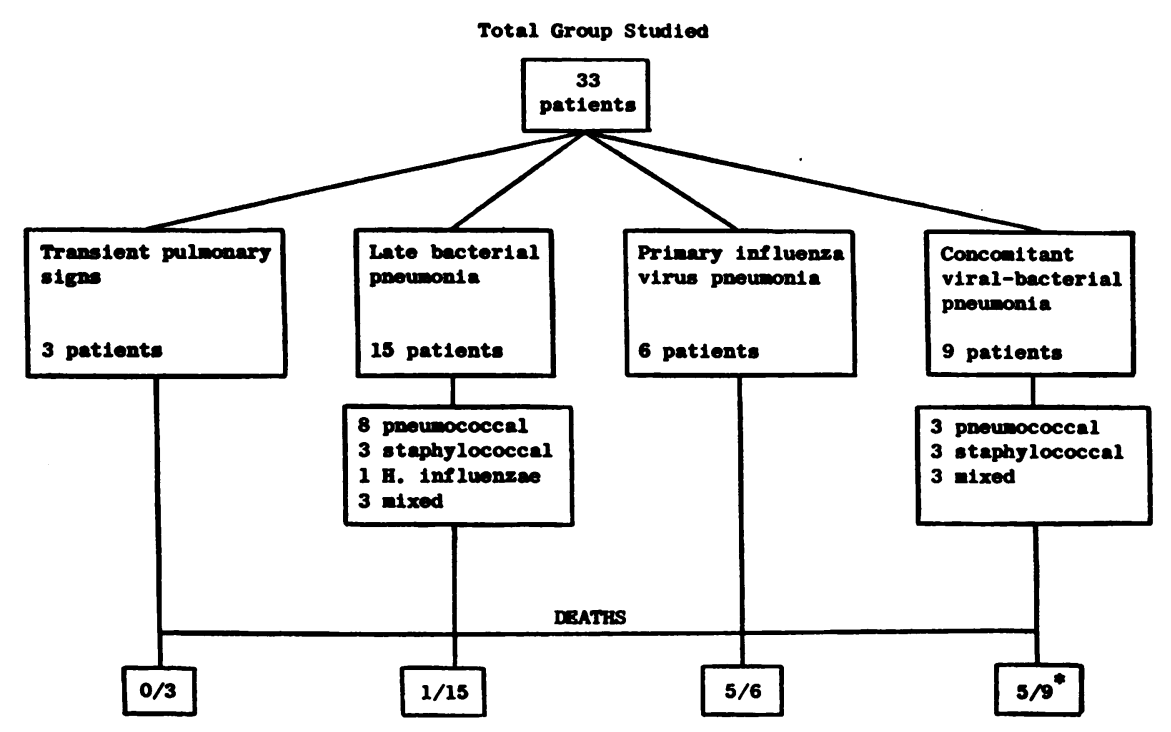

Fig. 30. The Pulmonary Complications of Influenza, The New York Hospital, 1957-58

Asterisk indicates two late deaths unassociated with acute illness.

of influenza might well account for the high mortality of influenza in young adults at that time. These factors rather than hypothetical changes in the virulence of influenza virus may explain the more terrifying face of pandemic influenza in 1918-19.

It thus emerges that severe and fatal influenza in 1957-58 was usually a disease of previously damaged hosts, as it appears to have been in the interpandemic decades (Table XV). As the problem of bacterial infection, so troublesome in 1918-19, has been modified by antimicrobial drugs, the problem of influenza virus pneumonia in patients with underlying disease has become proportionately more important.

It is to be anticipated that in future influenza epidemics the majority of deaths may well occur in patients with underlying disease who develop influenza virus pneumonia with or without concomitant bacterial infection. In such epidemics the relatively high risk of severe illness and death in the chronically ill may be reduced by prior specific immunization with influenza virus vaccines.

\section{SUM MARY}

1. During a prospective study of the 1957-58 influenza epidemic, 33 patients with pulmonary complications of influenza were admitted to The New York Hospital-Cornell Medical Center (see Figure 30). As these patients were studied it became apparent that their disease could be categorized on the basis of clinical and laboratory investigations into four distinct syndromes:

a) In three patients transient pulmonary signs were detected in the absence of roentgenographic evidence of pneumonia. These patients did not have bacterial infection, and recovery ensued on symptomatic treatment alone. This syndrome was believed to represent bronchiolitis related to influenza virus infection.

b) In 15 patients secondary bacterial pneumonia arose relatively late in the course of influenza. The etiology of this focal pneumonia was pneumococcal in eight, staphylococcal in three, mixed in three and related to the influenza bacillus in one. The course of infection and the response to therapy of these patients did not differ materially from that of uncomplicated bacterial pneumonia. Influenza infection was proved serologically, but virus could not be recovered from any of these patients.

c) In nine patients laboratory and clinical study indicated that concomitant infection with influenza virus and bacteria was responsible for the pneumonia observed. Of these patients, three had pneumococcal, three staphylococcal and three mixed bacterial infections. Despite adequate antibacterial therapy, three patients died during their acute illness, one with pneumococcal and two with staphylococcal infections. The Asian type of influ- 
enza $A$ virus was isolated from the lungs of these three patients.

d) Six patients developed a fulminating diffuse hemorrhagic pneumonia which led to death in five. No pathogen other than influenza virus could be related to this abacterial syndrome. These patients pursued a relentless course characterized by extreme dyspnea, hypoxia and failure to respond to antibacterial drugs. Influenza virus was isolated from five of these six patients, and directly from the lungs of four who died within 10 days of onset. Study of postmortem cultures and tissue sections of lungs failed to reveal bacteria.

2. Twenty-four of the 33 patients with pulmonary complications of influenza had chronic, underlying disease or were pregnant. Twenty-one of the 30 patients with roentgenographically confirmed pneumonia had pre-existing illness or pregnancy. Fourteen of these 21 had underlying cardiac disease which was of rheumatic origin in 10. Eleven patients died. Nine of the deaths occurred in patients with underlying disease, and five of these patients had rheumatic heart disease.

3. Myocarditis clearly related to influenza was not observed in this series of severely ill patients.

4. Signs suggestive of encephalitis were observed in three patients, but influenza virus was not recovered from the spinal fluid. Pathologic evidence of encephalitis was not found in four brains examined at autopsy.

5. A review of recent and earlier literature on pulmonary complications of influenza supports conclusions derived from the present study that:

a) Influenza virus infection per se may induce pneumonia in the absence of other microbial pathogens.

b) Underlying disease, and more particularly rheumatic heart disease, may be of importance in the genesis of influenza virus pneumonia.

\section{ACKNOWLEDGMENTS}

The authors gratefully acknowledge the technical assistance of Misses Marian Ann Melly, Nancy Fallon, Edna Lindsey, Phyllis Braslow and Vera Ungeheuer.

\section{REFERENCES}

1. Rogers, D. E., Louria, D. B., and Kilbourne, E. D. The syndrome of fatal influenza virus pneumonia. Trans. Ass. Amer. Phycns Suppl. 1958. In press.
2. Goodpasture, E. W. The significance of certain pulmonary lesions in relation to the etiology of influenza. Amer. J. med. Sci. 1919, 158, 863.

3. Smith, W., Andrewes, C. H., and Laidlaw, P. P. A virus obtained from influenza patients. Lancet 1933, 2, 66.

4. Mulder, J., and Masurel, N. Pre-epidemic antibody against 1957 strain of Asiatic influenza in serum of older people living in the Netherlands. Lancet 1958, 1, 810.

5. Blumenfeld, H. L., Kilbourne, E. D., Louria, D. B., and Rogers, D. E. Studies on influenza in the pandemic of 1957-1958. I. An epidemiologic, clinical and serologic investigation of an intra-hospital epidemic, with a note on vaccination efficacy. J. clin. Invest. 1959, 38, 199.

6. Podosin, R. L., and Felton, W. L., II. The clinical picture of Far East influenza occurring at the Fourth National Boy Scout Jamboree: Report of 616 cases. New Engl. J. Med. 1958, 258, 778.

7. Kilbourne, E. D. Studies on influenza in the pandemic of 1957-1958. III. Isolation of influenza A (Asian strain) viruses from influenza patients with pulmonary complications. Details of virus isolation and characterization of isolates, with quantitative comparison of isolation methods. J. clin. Invest. 1959, 38, 266.

8. Blair, J. E., and Carr, M. The bacteriophage typing of staphylococci. J. infect. Dis. 1953, 93, 1.

9. Van Slyke, D. D., and Neill, J. M. The determination of gases in blood and other solutions by vacuum extraction and manometric measurement. I. J. biol. Chem. 1924, 61, 523.

10. Van Slyke, D. D., and Sendroy, J., Jr. Studies of gas and electrolyte equilibria in blood. XV. Line charts for graphic calculations by Henderson-Hasselbalch equation and for calculating plasma carbon dioxide content from whole blood content. J. biol. Chem. 1928, 79, 781.

11. Chinard, F. P. Estimation of plasma volume by dye dilution method in Methods in Medical Research. Year Book Publishers, Inc., 1951, vol. 4, p. 38.

12. Noble, R. P., and Gregerson, M. I. Blood volume in clinical shock. I. Mixing time and disappearance rate of $\mathrm{T}-1824$ in normal subjects and in patients in shock; determination of plasma volume in man from 10-minute sample. J. clin. Invest. 1946, 25, 158.

13. Bessman, S. P. Personal communication.

14. Friedemann, T. E., and Haugen, G. E. Pyruvic acid. II. The determination of keto acids in blood and urine. J. biol. Chem. 1943, 147, 415.

15. Parker, F., Jr., Jolliffe, L. S., Barnes, M. W., and Finland, M. Pathological findings in the lungs of five cases from which influenza virus was isolated. Amer. J. Path. 1946, 22, 797.

16. Borden, C. W. Acute myocarditis; report of case with observations on etiologic factor. Amer. Heart J. 1950, 39, 131. 
17. Scadding, J. G. Lung changes in influenza. Quart. J. Med. 1937, n.s. 6, 425.

18. Stuart-Harris, C. H., Andrewes, C. H., and Smith, W. A study of epidemic influenza: With special reference to the 1936-37 epidemic. Medical Research Council, Special Report Series No. 228. London, His Majesty's Stat. Off., 1938.

19. Finland, M., Barnes, M. W., and Samper, B. A. Influenza virus isolations and serological studies made in Boston during the winter of 1943-1944. J. clin. Invest. 1945, 24, 192.

20. Maxwell, E. S., Ward, T. G., and Van Metre, T. E., $\mathrm{Jr}$. The relation of influenza virus and bacteria in the etiology of pneumonia. J. clin. Invest. 1949, 28, 307.

21. Giles, C., and Shuttleworth, E. M. Post-mortem findings in 46 influenza deaths. Lancet 1957, 2, 1224.

22. Hers, J. F. P., Goslings, W. R. O., Masurel, N., and Mulder, J. Deaths from Asiatic influenza in the Netherlands. Lancet 1957, 2, 1164.

23. Perrier, C. V., Hausser, E., and Paccaud, M. F. Sur quelques cas de broncho-pneumonie grippale d'évolution fatale; isolement du virus A/Asia/57 dans deux cas. Praxis 1957, 46, 1121.

24. Rock, J. A., Braude, A. I., and Moran, T. J. Asian influenza and mitral stenosis. Report of a case with autopsy. J. Amer. med. Ass. 1958, 166, 1467.

25. Commission on Acute Respiratory Diseases, Ft. Bragg, N. C., and The New York State Dept. of Health, Albany, N. Y. The relation between epidemics of acute bacterial pneumonia and influenza. Science 1945, 102, 561.

26. Stuart-Harris, C. H., Laird, J., Tyrrell, D. A., Kelsall, M. H., and Franks, Z. C. The relationship between influenza and pneumonia. J. Hyg. (Lond.) 1949, 47, 434.

27. MacCallum, W. G. The pathology of the pneumonia in the United States Army camps during the winter of 1917-1918. Monograph No. 10. New York, The Rockefeller Institute for Medical Research, 1919.

28. IVolbach, S. B. Comments on the pathology and bacteriology of fatal influenza cases as observed at Camp Devens, Mass. Bull. Johns Hopk. Hosp. 1919, 30, 104.

29. Opie, E. L., Blake, F. G., Small, J. C., and Rivers, T. M. Epidemic Respiratory Disease; The Pneu- monias and Other Infections of the Respiratory Tract Accompanying Influenza and Measles. St. Louis, C. V. Mosby Co., 1921.

30. Himmelweit, F. Influenza virus B isolated from a fatal case of pneumonia. Lancet 1943, $2,793$.

31. Michael, M., Jr. Staphylococcus aureus pneumonia with special reference to its occurrence as a complication of influenza. J. Amer. med. Ass. 1942, $118,869$.

32. Chickering, H. T., and Park, J. H. Staphylococcus aureus pneumonia. J. Amer. med. Ass. 1919, 72, 617.

33. Rogers, D. E. The current problem of staphylococcal infections. Ann. intern. Med. 1956, 45, 748.

34. Jordan, E. O. Epidemic Influenza. Chicago, American Medical Association, 1927.

35. Abrahams, A., Hallows, N., and French, H. A further investigation into influenzo-pneumococcal and influenzo-streptococcal septicaemia: Epidemic influenzal "pneumonia" of highly fatal type and its relation to purulent bronchitis. Lancet $1919,1,1$.

36. Winternitz, M. G., Wason, I. M., and McNamara, F. P. The Pathology of Influenza. New Haven, Yale University Press, 1920.

37. Dunn, F. L. Pandemic influenza in 1957. Review of international spread of new Asian strain. J. Amer. med. Ass. 1958, 166, 1140.

38. Langmuir, A. D., Pizzi, M., Trotter, W. Y., and Dunn, F. L. Asian influenza surveillance. Publ. Hlth Rep. (Wash.) 1958, 73, 114.

39. Stokes, J., Jr., and Wolman, I. J. The probable synergism of human influenza virus and staphylococcus aureus in a rapidly fatal respiratory infection. Int. Clin. 1940, 1, 115.

40. Burnet, F. M., Stone, J. D., and Anderson, S. G. An epidemic of influenza $B$ in Australia. Lancet 1946, $1,807$.

41. Mulder, J., and Verdonk, G. J. Studies on the pathogenesis of a case of influenza-A pneumonia of three days' duration. J. Path. Bact. 1949, 61, 55.

42. Evans, A. D., and Evans, M. Staphylococcal infection of the lower respiratory tract in adults with influenza. Lancet 1956, 1, 771.

43. Deaths from Asian influenza, 1957. A report by the Public Health Laboratory Service based on records from hospital and public health laboratories. Brit. med. J. 1958, 1, 915. 